\title{
Transformación de las subjetividades en psicoterapia: análisis de dos casos
}

\section{El contexto de atención}

Tos casos que se analizan en detalle en este capítulo (micro análiUsis), fueron atendidos en la cámara de Gesell de la IPs de la Universidad Santo Tomás, dentro de la Maestría en Psicología Clínica y de Familia, unidad académica a la cual pertenece esta investigación. Junto con los terapeutas responsables, autores de este texto, participaron como monitoras de la investigación y parte del equipo terapéutico, dos psicólogas estudiantes de la Maestría. A ellas les correspondió además hacer la recepción y la asignación de los casos a este proyecto, con el criterio de escogerlos al azar, de modo que al final lo determinante para la participación fue el horario disponible por parte de consultantes y terapeutas.

\section{El lenguaje usado en el análisis de los casos}

En coherencia con la metodología y con la intención de revelar los fenómenos de subjetividad, resonancia y autorreferencia, se hará explícita la voz de los terapeutas en primera persona, tanto durante la 
conversación terapéutica como en el texto del análisis de las sesiones y sus diferentes escenas. Se van intercalando las transcripciones de las sesiones con las reflexiones y reacciones de los terapeutas.

\section{El caso de Laura}

En este caso se realizaron cinco sesiones, con la participación del compañero y del padre de Laura, en una sesión cada uno. A cada escena se le asignó un título que sintetiza el asunto central abordado en ella y enseguida de la transcripción correspondiente la terapeuta expone sus vivencias y las reflexiones que la fueron guiando en el avance de cada sesión y del proceso en su totalidad. Así mismo se reportan apartes de las conversaciones en el equipo terapéutico y las reflexiones que de allí surgieron en la terapeuta.

\section{Pre-sesión}

La psicóloga responsable de la recepción presenta el caso de una mujer de veintisiete años, madre de un niño de un año; convive con su propio padre y no con el padre del niño. Menciona que la muerte de la madre de la consultante nueve años atrás aún la afecta y acude ahora a buscar ayuda porque no se halla y no sabe cómo organizar sus proyectos de vida. Esta información me hace pensar en una transición vital difícil y en la pérdida de fuentes de protección; me despierta curiosidad y simpatía al imaginar borrosamente el mundo de un hombre viudo y su hija, quizá madre soltera, atrapada en una sensación de fragilidad y de estancamiento vital. En el equipo se menciona posible depresión y desvalimiento e intencionalmente dejo pasar mis preguntas acerca de por qué está citada ella sola; pienso en que de haber sido posible, habría citado a alguna de las personas con quienes convive, pero acepto las condiciones del contexto de ayuda y además el hecho de que la consultante ya está esperando ser atendida. 


\section{Primera sesión}

Asiste Laura sola.

\section{Encuadre de la sesión ${ }^{1}$}

T. El proceso hoy va a ser de tal forma que nosotras vamos a conversar un rato, hacemos una pausa, yo converso con mis colegas para ampliar la perspectiva de lo que vemos de ti y de lo que vamos a hacer y luego regreso y te cuento cómo continuaremos.

L. Bueno.

T. Sé que eres Laura M.

L. Sí.

T. Te voy a decir lo que sé de ti y tú me ayudas a completar ideas básicas para yo armarme una imagen de tu vida. Pero antes ¿qué más quieres saber de mí? Creo que no te dije mi nombre, soy AH, soy psicóloga hace mucho tiempo, trabajo con la universidad, no sé qué otras curiosidades tengas sobre mí...

L. Pues básicamente por ahora eso, saber quién es (risa).

T. Igual, todas las curiosidades me las puedes comentar durante el proceso.

Comienzo usando la información de la recepción como principio de transparencia con los consultantes y eficiencia del tiempo en terapia. Es decir, creo en que tienen derecho a conocer abiertamente lo que sé y lo que pienso de ellos y presumo que hacer uso de esa información me permite ir más directamente al caso en lugar de tener una conversación banal. Desde que conocí a fines de los años setenta los planteamientos de Milton Erickson sobre conocer el modelo del mundo de los consultantes, los de Minuchin sobre joining o acompasamiento, los de Watzlawick y los del análisis transaccional sobre la comunicación humana, he intentado encarnarlos en el ejercicio de la terapia.

1 Convenciones: T: Terapeuta A. Hernández. L: Laura, la consultante. 
En este momento de la sesión, pretendo crear el ambiente de confianza y de apertura necesario para que Laura pueda expresarse y yo logre así representarme su mundo y resonar a sus vivencias, bajo la premisa de que son únicas, aunque yo deba acudir a mis experiencias y esquemas previos para hacerme una idea de su mundo.

Su aspecto físico reafirma el sentimiento de simpatía que ya me había despertado la información de la recepción. Revela menos edad de la que tiene, su rostro es dulce, con ojos vivaces y una sonrisa fácil que me hace sentir en conexión con ella muy rápidamente. Interpreto su risa ante la posibilidad de saber más de mí, como un sutil pudor que atribuyo tentativamente a nuestra diferencia de edad, a su idiosincrasia cultural en el trato hacia figuras de autoridad o a la sorpresa de que en este contexto de ayuda también ella tenga el derecho de preguntar. Sin mayor conciencia, acojo su postura como una suerte de permiso para aprovechar mi rol de mujer mayor y terapeuta para ofrecerle el clima de protección que tenue e hipotéticamente percibo como una de sus necesidades afectivas insatisfechas.

\section{Contexto y eventos significativos de la vida personal y de la familia de origen}

T. Sé que tienes 27 años.

L. Sí.

T. Que tienes un hijo de un año; no sé cómo se llama el bebé.

L. Mario.

T. Entendí que vives con tu papá y con el niño porque tu mamá falleció hace nueve años y fue un evento de tu vida que ha sido muy fuerte.

L. Sí, sí, señora.

T. ¿Cómo se llama tu padre y qué edad tiene?

L. Jaime, tiene 67 años.

T. ¿Y tu mamá a qué edad murió?

L. Ella murió de 48 años.

T. Joven. ¿Y cómo se llamaba?

L. Martha.

T. ¿Y qué le ocurrió para morirse tan rápido? 
L. Pues ella más o menos a los 40 empezó a sufrir cáncer en la trompas. Le hicieron tratamiento, se recuperó, a los tres años surgió nuevamente, se recuperó y de ahí para adelante ella empezó a trabajar mucho; mis papás tenían una salsamentaría.

T. ¿En qué sector?

L. En Corabastos. Ella se descuidó de salud y a los 46 años se sintió una masa extraña en el seno, se preocupó, yo la acompañé y tenía cáncer de seno.

T. O sea que fue una cadena...

L. Si, exactamente.

T. ¿Y tu papá hoy en día continúa con el negocio?

L. Después de que mi mamá falleció, el negocio decayó, porque mi mamá era la cabeza tanto de la casa como del negocio. Entonces mi papá se enfermó de la próstata.

T. ¿Tuvo también un cáncer?

L. No, afortunadamente. El negocio entró en muchas deudas y se lo quitaron. A partir de ahi mi papá se dedicó a hacer mantequilla y ese es su trabajo.

T. Entendi que tú habias estudiado una carrera técnica en el área del diseño...

L. Sí, sí, señora, técnico en diseño gráfico; terminé desde el 2011. A partir de ahí empecé a trabajar en una empresa de diseño como 6 meses; luego trabajé con el esposo de mi hermana, me contrató desde España por siete meses vía internet; luego me presenté a una empresa y me enteré que estaba embarazada; entonces me tocó estar en eso nada más. He estado como independiente, pero muy poco.

T. ¿Y tienes cuántos hermanos?

L. Una hermana mayor, ella tiene 33 años.

T. ¿Y qué hace?

L. Vive en España hace 6 años, es fisioterapeuta, está casada con un español y trabaja en su profesión.

T. O sea que están acá los tres: tu niño, tu padre y tú. Y ¿̇el padre del niño? ¿Quién es? 
En este breve relato identifico una serie de características de la familia: desde el punto de vista estructural aparece una familia con padre jefe de hogar, viudo, que convive con su hija, aparentemente madre soltera; siendo una familia pequeña, su dispersión me cuestiona sobre la calidad de los vínculos, dado que además de que la otra hija está muy lejos, la prematura ausencia de la madre, quien parecía ser el ingrediente aglutinador, los ha dejado quizá desorientados y desligados. De hecho, la serie de enfermedades de los padres, la muerte de la madre, las pérdidas económicas, la inestabilidad laboral, el nacimiento inesperado del bebé reflejan una importante carga de estresores no normativos. Ese panorama me permite pensar en que es muy comprensible la sensación de malestar y tal vez de desarraigo de Laura y empiezo a configurar la hipótesis de que su embarazo pudo haber sido parte de una medida no consciente de encontrar pertenencia y arraigo en otra familia. Me cuestiona el hecho de que aún después de nueve años, Laura y su padre no hayan logrado reorganizar sus vidas en forma eficaz y me pregunto cuáles serán además sus vulnerabilidades individuales y las motivaciones o los temores que les han llevado a vivir así.

\section{El compañero y la familia política}

L. Nosotros somos pareja hace cinco años; es mi novio, no hemos formalizado, aunque tenemos planes. Él sigue viviendo con su familia, es diseñador industrial; tiene 24 años, es menor que yo. Viaja mucho, permanece mucho tiempo en otras ciudades.

T. ¿O sea que por el lado de él qué familia hay?

L. Están los tíos y los papás de él. También tiene una hermana; ellos son un apoyo muy grande, ya somos familia. La hermana tiene 29 años y viven los cuatro, aunque el trabajo de ella, en una petrolera, también es de viajar.

T. ¿Cuáles son las razones para que la convivencia no esté compartida con Carlos?

L. Cuando quedé en embarazo él estaba en último semestre y con la tesis. Era muy pesado. Era muy difícil que pasara tiempo conmigo. Para él, el trabajo de grado fue muy pesado.

T. ¿Estudió dónde? 
L. En la Antonio Nariño.

T. Ah, ya. Él es profesional.

L. Sí. Fue complicado, inclusive lo ayudé y por todas esas cosas le quedaba más cómodo trabajar desde su espacio y por eso no hemos formalizado y por razones también económicas; ahorita es más para él bebé que para una convivencia de los tres.

T. O sea que puedo imaginar que los abuelos y la tía paterna colaboran...

L. En el momento en que estaba en la universidad sí; mi hermana también me colaboró y cuando él se graduó de la universidad consiguió trabajo rápido y él responde por los gastos.

T. ¿Entonces los planes de compartir la convivencia en qué punto están?

L. Pues complicados por el trabajo de él. En principio él no sabía que le tocaba viajar tanto. Ahora los viajes son de un momento a otro. Yo le he dicho que se vaya a mi casa, porque mi papá lo quiere mucho; lo recibiría bien. Pero él ve que el dinero tal vez no alcance, entonces ha hecho un ahorro para poder decir: "bueno, me voy contigo y le puedo ayudar a tu papá". Y cuando yo consiga trabajo ya va a ser mucho más fácil.

El relato ratifica mi impresión sobre la fragilidad del compromiso del padre del niño; si bien las razones académicas, laborales y económicas pueden ser válidas, la edad de Carlos y el hecho de que el embarazo no planeado se haya dado en su condición de estudiante e hijo de familia me llevan a preguntarme si él estará listo para asumir la construcción de una familia. No quiero dejarme llevar por prejuicios o intuiciones prematuras, así que pienso en la urgente necesidad de que él asista a la terapia para conocer su perspectiva.

Me queda la sensación de que Laura asume una actitud condescendiente frente a la situación, como si sintiera que no tiene méritos para pedir nada. No obstante, el papel de red de acogida que parece estar cumpliendo la familia política, iría hacia la confirmación de la hipótesis de que ella se adhiere a ese núcleo en búsqueda de pertenencia. Me abstengo de hacer retroalimentaciones al respecto porque me 
parecen apresuradas por la insuficiente información y considero mejor complementarla con la participación de Carlos. Esta fragilidad de la unión de pareja se suma a la de los vínculos en su familia, lo cual conduce a darle más sentido al malestar de Laura.

\section{Vivencia de la maternidad y cuidado del bebé}

T. ¿Y él bebé cómo está, para ti?

L. En cuanto a salud muy bien, pero si ha tenido problemas por peso y talla. No sabemos si sea un problema de herencia, hemos tenido preocupación por eso.

T. No crece.

L. Exacto, nos tiene preocupados, pues hace un mes que lo llevé, con mi tía que me colabora.

T. ¿Tía materna o paterna?

L. Materna, hermana de mi mamá. Desde que nació mi hijo nos inculcaba mucho que la leche materna era lo mejor; sin embargo ella es enfermera y me recalcaba: "empiézale a dar tetero, yo lo veo delgado, de pronto tu seno no es lo suficiente para él”. Fuimos a un médico que ella me recomendó, me puse las pilas, me dieron unos tips para lactar mejor, se vio el efecto y luego se estancó. Ella se preocupó bastante y ella tiene una señora conocida que cuida bebés y lo llevamos allá donde la señora; ya lleva un mes, ha subido de peso pero de estatura no.

T. ¿Y dónde lo ven? ¿Qué servicio tienen?

L. Salupcoop. Ahora la preocupación es esa y al mismo tiempo ha tenido problemas de motricidad.

T. Preocupaciones en su desarrollo.

A esta altura voy entendiendo que Laura no está sintiéndose validada como mujer, ni como madre, ni como trabajadora y con unos vínculos familiares también débiles, me parece muy comprensible que no encuentre un rumbo vital claro. Empiezo a pensar que para estar viviendo tantas incertidumbres tiene de todos modos cierta capacidad de control y otros recursos que le dan fuerzas para no rendirse, entre ellos acudir a la ayuda psicoterapéutica. 


\section{Definición del problema y recursos de cambio: miedo, soledad, apoyos limitados para ejercer la maternidad}

T. Entendí, en mis palabras, que vienes acá porque no has podido proyectar bien tu vida, como que tu realización no va por donde tú quisieras...

L. Cuando empecé a trabajar con mi cuñado, habia una propuesta de irme a España, tenía expectativas de irme a estudiar a España y la propuesta se cancela por un problema de él con la empresa. Luego empecé procesos con otras ofertas laborales y abi me enteré que estaba embarazada.

T. ¿El embarazo fue sorpresivo?

L. Sí, no fue planeado; fue muy duro para mí, tenía muchas expectativas. En ese momento pensaba mucho en mi familia, la familia materna es muy exigente, de genio difícil. Ellos me habian dicho que me fuera a estudiar, me habia dado susto y preciso llega el embarazo; aunque mi papá es todo lo contrario a la familia de mi mamá, es muy calmado, noble, pero tenía susto. Igual le conté y lo tomó muy bien.

T. Y me imagino que para él es rico tener un nietico.

L. Si, estaba contento. Entonces yo pensaba ¿̇y mi carrera abora qué? Y pensaba en mi pareja; él tenía también mucho susto, porque preciso en el último semestre.

T. ¿Y qué pasó? ¿Falló el método?

L. Sí. Yo venía con pastillas anticonceptivas pero las pastillas no me las cubría la EPS. Entonces acudi a unas más económicas y fallaron.

T. ¿Y finalmente cómo lograste asumir el embarazo, la maternidad? Porque son muchos cambios.

L. Cuando quedé en embarazo el primer apoyo fue de la hermana de él; para mí fue bueno porque tenía miedo de lo que pensara la familia de él; ella nos apoyó muchísimo, fue la que nos ayudó, intervino, me aconsejaba, nos entendemos muy bien. Ella también es enfermera, me enseñó cosas, en el curso psicoprofiláctico me ayudó, me empecé a tranquilizar. Mi hermana, a pesar de que en un principio se molestó, luego lo entendió y yo empecé a 
pensar: "bueno, tampoco es el fin del mundo", en algún momento las cosas tomaran otro rumbo. Así fue el embarazo, fue tranquilo, me cuidé mucho. Mi tía Piedad veía que yo me encerraba mucho, me decía que saliera más, porque estar embarazada no es una enfermedad. Entonces le hice caso, igual yo tampoco soy amiguera, soy más hogareña. Cuando nació el bebé tenía muchisimo susto; sin embargo tenía el apoyo de mi novio y la hermana de él. Ya el día del parto fue normal y a partir de abi él estaba en el punto más importante del trabajo de grado. Estuvo dos o tres días conmigo y tuvo que continuar con su trabajo de la universidad; entonces la hermana de él y mi papá fueron los más cercanos. El problema de mi bebé en cuanto al peso fue desde el principio, porque yo no daba buena leche.

T. Yo no soy experta en eso, pero dicen que no siempre la calidad de la leche es la misma.

L. Exacto, yo al principio no entendía eso, no entendía por qué no crecía. El tiempo de la dieta estuve con una señora cercana a la familia que nos cuidaba desde pequeñas; me dio consejos y cuando cumplió los días de irse me dio durísimo y la hermana de mi novio también se empleó; entonces me tocó sola. Mi papá me ayudaba en algo, pero hay muchas cosas que él no sabe hacer.

T. Hoy en día ha pasado un año de todo esto. ¿Cómo te sientes? Como para concretar más, ¿qué sería lo que quieres al venir acá?

L. Por el lado personal, mi idea es recuperar esas metas y aunque con mi bebé quería pasármela todo el tiempo hay otras cosas.

T. Claro, no es solo ser mamá.

L. Entonces el esposo de mi hermana también me aconsejaba; es que también me descuidé personalmente por estar tan pendiente del bebé y uno ni se da cuenta; es mi familia la que me ha visto. También por eso vine. Pasar mucho tiempo con él me estresó mucho, a veces llora mucho. Yo tengo un genio que exploto, pero por el bienestar de mi hijo me calmo.

T. ¿Ocurrió algo en particular que te hiciera decidir: "voy a buscar una ayuda psicológica"? 
L. Últimamente lo que ha pasado es que he tenido conflictos con mi novio por la ausencia, me da rabia y tengo en cuenta que obvio no puedo lastimar a mi bebé, pero hay momentos que me muevo por la rabia, pero no quiero eso, porque digamos que vengo de una familia con un genio difícil y no quiero ser así.

T. ¿Y Carlos sabe que estás aquí hoy?

L. Sí.

T. ¿Y qué pensó él?

L. Él dice que me apoya, hace muchos meses que le venía diciendo, igual es la primera vez. Él me conoce más que mi propia familia y me apoyó.

T. ¿Y de nosotros cómo supiste?

L. Buscando, me gustó más aquí.

T. ¿Por algo en particular?

L. No, no sé.

T. Pues anticipándome quizá a algunas cosas ¿piensas que si invitáramos a Carlos en algún momento él podría venir?

L. Sí, pues de hecho yo le dije; lo complicado es el horario de trabajo, de pronto en algún momento.

T. Sí, nosotros le damos las constancias que requiera, porque voy entendiendo que son varios ángulos de tu vida que están en un proceso de mejoramiento. Porque lo que me narras no me da para pensar que tengas el gran trastorno psicológico, sino que estás atravesando un momento de la vida; porque algo ocurrió que no estaba planeado dentro del curso que le estabas dando y eso a cualquier persona la desajusta. Entiendo que no te sientes bien en el aspecto personal, en tu situación conyugal ni como mamá, que es a lo que le has invertido año y medio de tu vida intensamente. Entiendo que quieres que te ayudemos a reorganizar el rumbo tratando de integrar y pulir lo que no está funcionando en cada una de tus situaciones. También me da la impresión de que por fortuna tienes una red familiar que te acompaña, te apoya y es un recurso importante para que puedas reforzarte, porque entendería yo que son fundamentales todas las dimensiones de tu vida. 
L. Sí, he perdido tal vez las ganas de continuar, a veces me da miedo, prefiero ni moverme ni nada.

T. Y si Martha viviera y yo le preguntara que piensa de lo que estás diciendo, ¿qué crees que diría?

L. Me regañaría tal vez por algunas cosas, pero al mismo tiempo se sentiría orgullosa por otras. Porque al tener a mi bebé me enfrenté a cosas que ni me imaginaba y ella desde arriba se ha dado cuenta que he sido capaz, aunque me falten ciertas cosas.

T. O sea que es otra fuerza que tienes en la vida.

L. Sí claro. Digamos que mi relación con ella.... Ella era callada, reservada, no era expresiva, entonces lo que más me afectó fue lo que no viví con ella; siempre la vi seria, de mal genio. Entonces cuando falleció, sentí que me faltó mucho por decirle, confiarle, contarle. Fue muy duro, porque el día en que falleció, ella ya no podía hablar, me hizo señas que fuera donde ella, me cogió las manos fuerte, y me miro a los ojos tratando de decirme algo; no pudo verbalizar, pero yo sentí que me pedía perdón. En ese momento oré porque le veía sufriendo del dolor.

T. Y quizá por tener que dejarte...

L. Sí, y efectivamente pensé: Dios, haz que descanse y en ese momento ella falleció.

T. O sea le ayudaste a que se liberara...

L. Sí, es algo que no cuento seguido porque fue muy intenso.

T. Gracias por contarme.

L. Lo vivi de ese modo y fue significativo, me soñé con ella dos días después y ella llegaba y me decía que solo yo la podía ver, son cosas que quedaron.

T. ¿Y eso fue agradable para ti?

L. Sí, pienso mucho en ella y mi bebé físicamente se me parece mucho a ella y todo el tiempo la tengo ahi presente.

T. Bueno. ¿Y cómo te sientes ahora aquí con nosotros?

L. Es liberador contar las cosas, porque a veces, de pronto mi hermana me decía que quizá no me sentía cómoda con mi familia hablando de esto y me dijo que sería pertinente este espacio.

T. ¿Y sí ha sido así? 
L. Sí, señora.

T. Bueno, me alegra. Haremos una pausa para conversar con los colegas y en unos minutos regreso.

Me conmueve su vivencia que percibo como de desamparo y en cierta forma de visión de túnel. Me represento su mundo después del embarazo y del nacimiento del bebé como un espacio de creciente soledad, en el cual se asusta y se entristece, además porque a pesar de su dedicación, el desarrollo del niño no muestra su eficiencia como madre. Me imagino los múltiples comentarios contradictorios y evaluativos que se hacen socialmente alrededor de una madre, sobre todo si es primeriza y no tiene ninguna ayuda confiable, sea por parte de su propia madre, como se hace por tradición, o por parte del sistema de salud, como se hace ahora por lo que desde mi punto de vista corresponde a la creciente medicalización de la vida.

Tengo la impresión de que las personas en la red de apoyo asumen con Laura relaciones verticales, en el sentido de que le dan instrucciones y consejos, pero en verdad poco la ayudan en la cotidianidad de manera efectiva para que pueda ocuparse mínimamente de sí misma; en cambio sí la critican por el que juzgan un descuido por incapacidad. Así voy imaginando el círculo vicioso que se cierne sobre Laura, generador progresivo de una especie de desierto afectivo. En ese medio emocional, es entendible que se torne irritable y exigente con Carlos, quien en su calidad de padre debería estar más presente; pero como hay en el ambiente la sensación de que él ya hace bastante haciéndose cargo de los gastos del niño, los reclamos de ella no obtienen respuesta y más bien sí reproches que incrementan su vivencia de incompetencia y desvalimiento. El reconocimiento explícito de conflictos son su novio, más el resto del relato, confirman la impresión de que el problema se asocia a una sobrecarga de tensiones acumuladas por el cambio de roles, principalmente al convertirse en madre sin el apoyo ni la protección necesarias.

Me parece muy importante subrayar la definición del problema como transición vital y no como un trastorno psicológico porque considero que ese es uno de los riesgos adicionales que corre en su entorno, 
donde cada vez es más señalada por su comportamiento. Me aterra que dentro de todas las voces que intentan ayudarla lleguen a definirla como paciente mental, lo cual no sería difícil pues su descripción daría para diagnosticarle una depresión. Con todas estas ideas que me hacen pensar en que las ayudas que recibe no son incondicionales, me aproximo a la evocación de la madre como fuente de autoprotección interna, más aún cuando sus palabras me alertan por sutiles ideas de muerte. Por fortuna mi intuición resuena con la experiencia tan significativa antes de la muerte de la madre y aprovecho para subrayar la capacidad de Laura para ayudarla a liberarse del sufrimiento. No obstante, también aparece cierta "deuda" afectiva mutua en la relación con la madre, a pesar de que según Laura solo ella pudiera verla después de su muerte.

El hecho de que me confíe esa vivencia tan íntima, me ratifica no solo su confianza en mí como terapeuta sino la resonancia en la que progresivamente vamos entrando. A pesar de que sería fácil pensar en que me endilga un rol maternal, prefiero pensar en que lo mejor que puedo aportarle es mi propia experiencia en búsqueda de la autoafirmación y la autonomía como mujer. Si bien reconozco su aparente fragilidad en el momento, no quiero arriesgarme a que surja otra relación complementaria donde ella asuma el rol pasivo. No me voy a negar a adoptar gestos de protección hacia ella, ni tampoco le temo a lo que desde ciertas visiones fuera una relación de dependencia, pero creo que precisamente se trata de ayudarle desde afuera a rehacer y a limpiar los vínculos con las personas significativas de su vida. Esta es otra razón más para que venga con su compañero a la siguiente sesión.

Connoto muy positivamente su necesidad de apoyo y vinculación porque me parece una necesidad humana y por el contrario me parece contraproducente cuestionar esa necesidad; porque creo que uno solo puede ser independiente, cuando siente que puede depender. No tengo la sensación de que Laura se vaya a colgar inadecuadamente en la relación terapéutica; me parece que es una mujer joven que atraviesa situaciones normales dentro de la evolución de su vida. Propongo convocar a su compañero para una próxima ocasión para tener referentes sobre ese subsistema de pareja que existe como expectativa 
futura y que va a determinar en la medida de la fuerza que tenga, lo que ella decida hacer; porque Laura cuenta con él aparentemente a ciegas, pero me pregunto qué es lo que los mantiene unidos y su vínculo me parece frágil.

Acudo a la premisa proveniente del análisis transaccional de que el afecto y la protección son necesidades emocionales básicas que se acentúan ante el establecimiento de la simbiosis con el bebé. Desde ese punto de vista, es absolutamente válido que las madres requieran que otras personas, en especial el padre, cuiden de la madre y el hijo y generen un ambiente seguro y estable, asunto que falla en este caso, plagado de incertidumbres afectivas y de restricciones materiales.

Dentro de este cuadro, alcanzo a preguntarme cómo, a pesar de las aparentes limitaciones de Laura, no ha caído en una franca depresión posparto, pues sus circunstancias la predisponían y reafirmo la urgencia de validar todas sus emociones, calificarlas como adecuadas para los hechos que vive, destacar sus recursos personales, conocer y ampliar las posibilidades de su red vincular.

\section{Cierre de la primera sesión}

T. Bueno, ¿pensaste en algo en particular?

L. Pensaba en qué pasará de acá en adelante, luego de haber venido.

T. ¿Visualizaste algo?

L. Cosas buenas: poder mejorar y hacer lo que he querido, porque me he retraído.

T. Claro, pero me parece que es muy humano que en momentos de la vida uno requiera de esto para levantarse. Me parece muy positivo que te des cuenta que necesitas el empujón, porque lo grave sería que te quedaras esperando a ver si el hada madrina te lo da para continuar en la vida. ¿Cuál dirías que es la situación en la vida en que hayas tomado una decisión en la que tú misma sacaste tu fuerza?

L. De todo lo que he hecho en mi vida, pienso que fue cuando mi mamá falleció. Yo estaba en segundo semestre. Ella falleció, yo tenía muchas ganas de estudiar lo que había elegido desde el 
colegio; no se pudo en universidad por razones económicas; a mi me fue muy bien en primer semestre y en el segundo fallece mi mamá. Recaí, quise retirarme y de pronto dije: no, voy a seguir. Pero de ahí para allá hubo muchos altibajos, perdi muchas materias, porque perdi la responsabilidad, ni mi familia se había dado cuenta y mi papá estaba en el negocio. Nadie estaba al tanto; yo tampoco le contaba a nadie. Entonces así fue: duré así como dos años y medio; yo no sabía qué pasaba y ya en un momento dado dije: ya, haré esto por mí misma, conseguí trabajo, me pagué las materias perdidas y me gradué.

T. Pues es que pensamos que ese es un rasgo tuyo; así que te pediré que hagas una tarea y es que al comenzar cada dia, pienses en qué quieres hacer para tu mejoramiento personal; tú eliges y al final del día evalúas si lo cumpliste y nos cuentas. La otra cosa es que puedas venir con Carlos dentro de quince dias. Consideramos que es la persona de quien hay que saber cómo cuentas con él para armar la continuidad de tus proyectos; por eso nos parece fundamental hablar con él para poder avanzar. Haremos en total cuatro sesiones más. Porque creemos que se trata de darte un empujoncito más firme, identificando cuándo es que necesitas de ellos, porque somos humanos. ¿Cómo te vas?

L. Contenta. Lo tenía en mente hace mucho. Ya por lo menos di este primer paso.

Tengo la sensación de que para afianzar el vínculo terapéutico y sobre todo activar sus recursos de cambio es indispensable encontrar en su historia momentos exitosos de afrontamiento y por ello le pido directamente que los recuerde. Su relato no solo cumple con este objetivo sino que además muestra una secuencia que podría representar la pauta que se repite en este momento vital, en el sentido de que un sentimiento de desarraigo desorganiza el curso de su vida, hasta cuando se reencuentra consigo misma y decide retomar sus proyectos. Pienso que algo así ocurre en este momento y lo capitalizo como un buen indicador de sus posibilidades de cambio. 
Le doy una tarea un poco inespecífica, con la principal intención de que mantenga el contacto con el contexto terapéutico, de modo que si además logra hacerla ya habrá ganancias interesantes en función de la recuperación de autoconfianza. Si bien me llama la atención comprender el vínculo con su hijo, considero que ella necesita reconectarse con el mundo adulto para poder seguirse validando, porque es lo que le inquieta y en ese contexto el hijo se puede volver el escudo para que no haga nada más.

El reconocimiento de las experiencias positivas busca activar la capacidad resiliente de la consultante y la metáfora del empujón conduce a naturalizar esa necesidad como un recurso a aprovechar en el contexto de ayuda, entendiendo que no se trata de salvarla sino para posibilitarle que se empodere. Esto se asocia con la noción de que la precariedad es parte de la vida pues nadie es autosuficiente. Esto no riñe con la autonomía, porque yo puedo pedir ayuda con toda conciencia, distinto a que me tenga que dejar caer para que vengan y me ayuden. Es decir, estamos todo el tiempo en el espectro de autonomía, dependencia, independencia y codependencia y eso tiene que ver en el caso con la concepción de cómo emerge la subjetividad, en el sentido de la manera como la llevamos a pensar de sí misma y a connotar muchos elementos de su subjetividad y de su mundo subjetivo, que cambian de color.

Específicamente, ante la que queja inicial de "no me hallo", ir recorriendo los diferentes roles que asume como cónyuge, madre, hija y como persona, es una forma de situar su inconformidad para hacerla aprehensible y redefinir el problema. Porque mi prejuicio o mi creencia es que justamente el mundo social es un juego de roles en el sentido que es un inter juego de mutuas expectativas que a veces encajan y a veces son frustrantes y generadoras de conflicto y por lo tanto se trata de ayudarle a esclarecer sus propias expectativas y necesidades y a que saque su fuerza personal que parece menguada en el momento.

Me alegra que los colegas hayan comprendido mi aproximación al caso y la valoren. Me doy cuenta de la simultaneidad de procesos en la subjetividad del terapeuta, donde se conjugan la intuición, la 
vivencia, la observación y la clasificación de las interacciones, de modo que la conciencia es como un radar que va rotando por distintos focos internos y externos. Se diría que así se evidencia la conciencia de consultante y terapeuta encarnada en la vivencia de la interacción.

\section{Segunda sesión}

Quince días después. Asiste Laura con su compañero.

\section{Acogida al compañero de Laura}

T. Bueno, entonces me presento. Soy AH, no sé qué te contó Laura de la experiencia de hace quince dias...

C. Pues la verdad, no mucho.

T. Pero de lo que te contó ¿qué te pareció interesante?

C. Bien. Sí me dijo que era un espacio donde expresó lo que sentía y me dijo que necesitaba que viniera la persona que estuviera más con ella y en ese caso soy yo. Entonces saqué el espacio.

T. Ah bueno, está bien. No sé qué quieras comentar antes de arrancar. ¿Cómo te cayó la acogida que tuvo Carlos para venir?

L. Pues le había comentado. Pensé que no podía pero afortunadamente pudo sacar el tiempo. Es importante porque sé que nos va a ayudar.

T. Bueno, que hayan llegado habla bien de los dos; porque por la imagen que me llevé tienen una relación bonita, quieren realmente mantenerse juntos y me parece significativo que asi lo hayas tomado: que viniste porque eres una de las personas importantes para Laura. Que tú mismo te des ese lugar, habla bien de la relación, porque es como que a la hora de la verdad, Laura puede ratificar donde está en tu vida... No me quedó claro en qué trabajas...

C. Yo estoy en la parte de montajes de Almacenes x y $\mathrm{z}$ a nivel nacional.

T. ¿Eso tiene que ver con lo que estudiaste?

C. Sí. 
La apariencia de la pareja es agradable. Me dispongo a aprovechar de la mejor manera la presencia de Carlos, dadas las interferencias de su trabajo para proponer un proceso terapéutico con su continua participación. Intento contextualizarlo no solo en la terapia sino sobre todo en la relación con Laura y por ello indago desde el comienzo cómo se posicionan los dos en ambas situaciones. Me llama la atención que él se defina como "la persona que está más con ella", sin referirse a la naturaleza de la relación de pareja y que ella en apariencia viva ese acompañamiento como una excelente coincidencia y no como algo inherente a la condición de pareja. Esto me hace pensar en que para Carlos el problema es de ella y las respuestas de ambos me animan a entrar de lleno a la exploración sobre la relación. Creo que es la mejor forma de ampliar la definición del problema sin hacer una discusión explícita sobre el tema. Carlos me parece una persona directa, activa, fuerte, que me invita así a abordar los asuntos a mi juicio pendientes de la misma forma.

En ese momento tengo más vívida la sensación de ser una especie de autoridad parental y protectora de Laura, que concreta a los pretendientes de las "doncellas" para que se mantengan las distinciones de roles y de límites entre los nuevos sistemas que se forman en las transiciones vitales. Se va acentuando mi impresión de que en buena medida el malestar de Laura surge en las confusiones contextuales propias de tales transiciones que ocurren por fuera de los rituales sociales de formalización de las uniones y en espacios de tiempo demasiado cortos para que los involucrados asimilen paulatinamente los cambios.

Estos pensamientos están siempre presentes en mi trabajo psicoterapéutico porque he confirmado clínicamente la función transformadora de los rituales sociales y culturales, que implican como dice Houseman (2003) que una persona entra al ritual siendo una y sale siendo otra. En este caso, sería evidente la confusión, pues con todo y la presencia de un hijo de un año, siguen siendo "novios"; no porque por razones morales sostenga la exigencia de pasar por ceremonias legales o religiosas, sino por los efectos psíquicos y sociales que tiene el 
hecho de adquirir el permiso social para ser llamado "el esposo o la esposa de...”, con todas sus consecuencias para la organización de la cotidianidad, no solo al interior de la pareja sino en las relaciones con el resto de la familia y el núcleo social más amplio. Sobre este tema también tengo muy presentes las premisas de la comunicación de Watzlawick, en especial acerca de los conflictos por confusiones entre la naturaleza y el contenido de las relaciones.

\section{¿Cómo son pareja y cómo son padres?}

T. Perdón que yo voy a pasar al grano. Entonces la misma pregunta va para ti, pues entendí que son los padres de Mario y tienen una relación que no sé cómo llamar. Si a ti no te incomoda me agradaría que habláramos un poco de eso. En realidad ¿ustedes que son?

C. Ahorita estuvimos hablando que por el bienestar del chiquitín y nuestra relación, en abril ya vamos a vivir, porque ya decidimos y ya es justo. Mario llegó de imprevisto, pero es la persona especial para nosotros, como le decía a ella, ya tenemos historia de altibajos y lo único que veo es los estados de ánimo; uno como hombre entiende los estados de ánimo, pero a veces como que uno no sabe.

T. Te desconcierta.

C. Vinimos precisamente a buscar esa ayuda es por eso, por los estados de ánimo, uno se desconcierta con los cambios de humor, entonces ella puede estar muy bien o muy abajo. Gracias a Dios lo que dice ella para mí es muy importante; creo que uno tiene que ceder; por ejemplo yo soy el apoyo de ella, pero a veces es muy duro, porque uno tiene la responsabilidad que es ella y Mario y a veces se complica cuando ambos estamos abajo y uno tiene que estar siempre arriba. Por ejemplo, no sé si tú le quieras comentar lo de ayer...

L. Mmm... ¿qué?

C. Lo de ayer es que, llegué de viaje de Yopal, descansé y me fui a la empresa. A Mario lo cuidan hasta las cinco; la llamé a ella y estaba enferma y me dijo que no quería hacer nada. Entonces 
lo que yo bice fue decirle: párate de la cama y no se paraba de la cama, hasta que se paró. Es como si yo la guiara con mi voz, que se bañe... Y no vivimos cerca, ella vive en Kennedy y yo por los lados de la 68 con Boyacá; por eso es la mudanza, para estar cerca y ayudarla. Siento que ella depende gran parte de mí, es desgastante; yo quería dormir, pero era el bienestar a ella... y quién recogía a Mario...

T. Claro... ¿y eso fue a qué hora?

C. A las tres de la tarde

T. ¿Y al niño lo recogieron?

L. A las 5.

C. Entonces fue como decirle a ella, no hay lío. Porque tenemos antecedentes, no me gusta gritar. Ayer hasta que no escuché la ducha no colgué y como llegué muy rendido no hablamos mucho. Eso es de lo que te quiero comentar y de lo que yo vivencio.

T. Ah, lo de los estados de ánimo. ¿Cómo es tu situación ahí?

L. Ayer y antier estuve enferma; después del parto tengo el período irregular y el método anticonceptivo me ha afectado los estados de ánimo; la vez pasada que me llegó el periodo fue terrible y ahora de nuevo; me siento muy mal y hay momentos en que no me dan muchas ganas de hacer las cosas, se me baja el estado de ánimo, trato de calmarme y últimamente me está pasando eso mucho, así como hay momentos en que hago muchas cosas en el día.

T. Y desde tu punto de vista ¿cómo estás?

L. Pues pedí cita; yo tengo un problema en la columna, siento mucho dolor en el coxis, pero no me he hecho revisar; me harán un examen al parecer tengo una vértebra corrida y sufrí en el embarazo y con el período me afecta.

T. ¿Pero tienes un ginecólogo y las ayudas médicas que te estén haciendo un seguimiento?

L. Pues, Carlos me afilió a la IPS de él; le comentaba eso a la doctora y me mandó cita que no he tenido. A veces no sé; esperar a ver si puedo usar otro método, pero me da susto por lo que ya 
pasó; obviamente es de mucha prevención. Siento que eso me ha afectado mucho y lo que te comentaba la vez pasada de las cosas del bebé. Es una responsabilidad que antes no tenía.

T. ¿Y del bebé que es lo que te exige?

L. Por ejemplo, lo que más me estresa son los problemas de alimentación que a veces tiene; no le he vuelto a dar seno.

T. ¿Desde hace cuánto?

L. Hace más o menos mes y medio; entonces toca que lo cuide una persona para que reciba.

T. O sea, con personas ajenas a ustedes él recibe...

L. Sí. Entonces eso me estresa por pensar que está bajo de peso, quedado de crecimiento. Y digo: ¿será que la embarré, no hice lo suficiente, en que fallé? Básicamente es eso.

T. ¿Y tú cómo ves eso del desarrollo del bebé? ¿Cómo lo percibes?

C. Pues sí, la doctora nos decía que está un poco quedado, pero igual es también nuestra contextura y yo tengo un antecedente de prematuro; mi hermana que es enfermera nos dice que está bien. Entonces es un esfuerzo. Yo le decía a ella que busquemos jardines donde lo estimulen.

T. Qué bien.

C. Y para el beneficio de ella que quede cerca de la casa; porque la prioridad es que no se estrese ni ella, ni Mario porque él bebé lo recibe. Sino que a veces es complicado, yo me siento con mucha responsabilidad y no sé si ella le ha dicho mucho, pero el papá en eso no es que la apoye.

L. O sea lo que pasa es que cuando planeamos cosas con Carlos a mi papá le gusta estar en la casa, yo solía decirle que saliéramos pero no le gusta.

T. Él es como muy pasivo...

C. Pues yo entiendo; tiene 67 años y las prioridades son otras; sino que cuando hay una situación asi él no cree en que buscar ayuda puede servir.

T. O sea ¿él no te estimula? ¿No toma iniciativas?

L. No. 
C. Exacto. Yo le decía a ella, busquemos trabajo, pues le pido comprensión, porque mal o bien tengo este trabajo y yo nunca le saco en cara. En la familia de ella dicen eso y yo le digo: "vea, yo soy su pareja y no le estoy diciendo nada", yo rebusco, hago trabajos fuera. Es un apoyo, porque mi hermana también sufrió un problema y la ayudamos y yo no quiero que ella llegue a ese punto en que diga no, no más. Siento ira cuando ella dice $y$ opina que es inútil; es algo que yo equilibro y se me da con facilidad; yo soy el que lo cargo así sea con coche, pero yo no sé qué pasa con ella que se critica tanto. Eso es lo que yo quiero con estas terapias porque hoy me dieron permiso, pero después no sé.

T. Claro lo organizamos de tal modo que sea útil y viable.

C. Es buscar algo para que ella bloquee eso.

T. Claro, porque yo entendi que tuviste una época en que te dejaste caer, pero volviste a ser activa y a retomar el rumbo de tu vida; ahora entiendo cómo esta situación del niño te ha afectado muy duro y es válido porque desafortunada o afortunadamente el éxito de los hijos se vuelve como la calificación del rendimiento $y$ dedicación de la mamá; del papá también, pero sobre todo de la mamá que está con ellos el 100\% del tiempo. Entonces tu autoestima está basada en ser buena mamá y esa es la que tiene el niño gordo, rosado... y son cosas que acaban por darte un golpe en la cabeza. Pero bueno, tienes muy buen gusto, porque Carlos, da la impresión de que tú escogiste a Laura por razones que ahora me dirás, pero has asumido realmente un papel muy protector, responsable y como que la asumiste en tu vida.

C. Si y a Mario también. Laura sabe que no soy tan emotivo y me dice que soy insensible, porque nunca lloro; solo lloré cuando nació Mario y cuando vi que no comía, pero no es que sea insensible, sino que son diferentes formas de ser.

T. Pues yo no podría decir cuál de los dos es más sensible, porque si no lo fueras, no podrías pactar, ni dar por escrito lo que a ti te pasa, tu sientes que Carlos te lee muy bien, otra cosa es que 
cada uno exprese sus sentimientos de diferentes maneras, tu te contienes un poco más y piensas más acerca de lo que sientes. Menos mal porque sentarnos todos a llorar... (Risa).

L. (Risa).

Carlos no responde directamente a la pregunta por la naturaleza de la relación sino que antepone el bienestar del niño; aunque dice que ya es justo convivir, lo plantea para dos meses después. Deja ver con claridad las que serían sus prevenciones para la consolidación de la unión, por no saber cómo manejar los estados de ánimo de ella y la historia de "altibajos" en la relación. Todo esto lo lleva a describirse como abrumado por sentir no solo el peso de la responsabilidad económica sino también el de la carga emocional. Me sintonizo con él en su queja por la dependencia de Laura y me pregunto hasta dónde ella está desplegando un comportamiento de manipulación emocional, propio de las relaciones simbióticas.

Sin embargo, los argumentos de ella sobre su salud y su cansancio me recuerdan su sensación general de sobrecarga y por eso indago sobre las soluciones efectivas que ha buscado para esos problemas. La escena donde él le da instrucciones y seguimiento por teléfono hasta para que se bañe, me parece patética y preocupante por los extremos a los ha llegado Laura quizá para presionar la toma de decisiones de la pareja. Lo que ocurre, como en todos esos casos, es que está logrando lo contrario a sus deseos, pues como él lo dice, es desgastante, dado que las soluciones intentadas para aliviarla con la crianza del niño no han sido exitosas para que supere su sentimiento de incompetencia como madre y más bien lo desestimulan de formalizar la unión. Se vislumbran también tensiones entre Carlos, el padre de Laura y su familia extensa, por las cuales aumenta en él la sensación de sobrecarga emocional.

Este difícil panorama me conduce a rescatar los recursos de Laura, a connotar positivamente la postura de protección de Carlos y a explorar los motivos positivos para estar juntos. 


\section{Motivos para permanecer en la relación}

T. ¿Pero qué fue lo que encontraste en Laura para meterla en su vida, y a la vez que encontraste en Carlos, para que cada uno decidiera incluir al otro en su vida?

C. Cuando la conocí, lo que me llamó la atención era esa ternura; porque venía de relaciones con peladas que no eran estables. Ella no. Era de estar en la casa, estar bien, esa ternura, no esas cuestiones de salir a tomar, sino de ver una película un plan más acogedor. Sonará extraño, pero lo que ella emite es eso, dan ganas de abrazarla, besarla y eso no se ha apagado, pues es lo que hago siempre; es lo que me llamó la atención. Me gustaba muchísimo física y personalmente, que es muy juiciosa, también que no fue fácil; duramos que sí, que no, hasta que fuimos novios, compartíamos y teníamos los mismos gustos; y el apoyo que ella me brinda también. Eso fue lo que me llamó la atención; la comprensión de ella siempre me ha motivado, pues hay cosas que uno dice que puede mejorar, pero pocas personas valoran eso.

L. Pues en mi caso cuando conocí a Carlos, fue chistoso, yo dudaba mucho porque él es menor que yo.

T. Menos mal que tú no revelas la edad.

L. (Risas) Menos mal, pero yo como que no veía en mi camino tener algo con alguien menor que yo. Cuando lo conocí me sentía tranquila, podía ser yo misma, a veces como que con otra gente uno ocultaba ciertas cosas, como que no podía...

T. No podias ser tan trasparente.

L. Si, con él si me sentía yo así; desde el principio le contaba cosas de mí, mi familia y me sentía cómoda porque no con muchas personas suelo ser así. Eso me atrajo de él, porque me escuchaba, no era el típico hombre que se acerca a uno por otros motivos, fue diferente. Además también como me acogió la familia, entonces más me sentía yo cerca de él, ellos han sido abiertos, cariñosos, entonces siempre sentí en ellos y en él lo que ya no hubo en la mía. Entonces fueron varias cosas, él y su entorno 
que me hacía sentir mejor, como protegida y la forma de ser de él extrovertida y juiciosa, que es rápido para las cosas. Yo tiendo a tener mucho acercamiento con las personas que son así, como más despiertas que yo; mi mejor amiga es también así.

T. Te activan.

L. Exacto, eso fue lo que me atrajo, no fue tanto un gusto de buenas a primeras, fue con el tiempo y para mi es muy importante.

Encuentro que la conexión emocional y la intimidad como personas son las principales motivaciones para estar juntos. Pienso que la inesperada llegada del bebé diluyó esa dimensión de su comunicación, de modo que de una relación de pareja simétrica, pasaron a una complementaria donde él protege y ella se fragiliza. Se confirma la idea de que ella adoptó también a la familia de él como fuente de arraigo y de fuerza. Se infiere la sensación de incompetencia más generalizada en Laura, la cual la habría predispuesto a la actual postura simbiótica y a su sensación de estar abrumada con la maternidad. Se comprende también el impacto que tiene para ella el posible fracaso de la relación y por lo tanto la activación de mecanismos de creciente pasividad, que la llevan incluso a incapacitarse. Por eso paso a conocer más de sus dispositivos para tramitar sus emociones y asumir su rol de madre.

\section{Del estado de ánimo y la apropiación del rol de madre}

T. Y eso de tus bajos y altos aparte de lo que hemos hablado, ¿cómo es? Porque me da la sensación de que aunque ha pasado un año, tú como que no has terminado de digerir, asimilar el rol, no desde el punto de vista afectivo, sino que desde la vivencia que yo tengo, no sé si es lo que sientes, como si te faltara algo para dar un salto y sentirte apropiada de la situación.

L. Si, uno a veces se pregunta ¿por qué? En el caso de Mario que llegó de un momento a otro. ¿Por qué en este momento, cuando tenía otras expectativas? En este año siempre ha sido por eso; porque me ha tocado mucho tiempo con el bebé sola, obviamente he tenido a Carlos, que está a mi nivel, pero no he encontrado a alguien con experiencia que me ayude; que me 
diga cómo puedo hacer las cosas, pues está mi suegra a ratos, mi papá lo que ya comentaba, tengo unas tías que se preocupan pero juzgan mucho; entonces me ha tocado juzgarme a mi misma y al mismo tiempo decir, sí lo estoy haciendo bien. Han sido muchas cosas.

T. O sea no te la crees.

L. No me la creo. Sí, hay momentos donde no me la creo y digo: uy! en qué momento pasó todo esto. Cuando le estábamos celebrando el cumpleaños al bebé y siento que no trabajo, las personas me ven a mí, ven al bebé y dicen: bueno ya tiene un añito, debería estar haciendo esto y lo otro.

T. ¿Y de quiénes son esas otras voces?

L. Mi tía Patricia, aunque la quiero mucho a veces juzga mucho; yo viví con ella cuando mi mamá falleció; sin embargo en el trayecto de mi vida hemos vivido varias veces; yo sé que ella me quiere mucho, pero a veces esas partes de afecto se opacan cuando me dice: "pero mira que Mario, mira que esto..."

T. Es demasiado crítica. Además es que creo que abora la sociedad le ha puesto mucho volumen a esa idea que uno no nace aprendido como papá, que los niños no traen un manual, pero en realidad eso no es cierto; es un hecho natural de la vida. Quitando un poco todos esos discursos si se ponen la mano en el corazón y observan lo que han hecho y lo que ha resultado, ¿tú en realidad cómo ves a Laura como mamá?

C. Bien, porque no ha tenido ese apoyo de la mamá; hago de cuenta mi mamá, ella está ahí, con mi hermana. Y es bien porque todo mundo dice "que bebé tan hermoso", uno cuando lo lleva a algún lado todo mundo lo mira.

T. Entonces les quedó lindo (le muestran una foto a Ángela).

C. Yo digo si fuera otra mamá, como esos niños que uno ve sucios, con costricas, pelo sucio y Mario nos quiere, hacemos todos los esfuerzos; ahora está en Compensar en un curso de natación para que se estimule; si no fuera así, por Laura, yo diría que Mario no sería el niño que es, no tendría esa mirada de observador. 
T. Sí, es un niño que se ve con su miradita brillante.

C. Y él la busca, porque a veces estamos los dos, él la ve y la busca; conmigo es lo mismo. Fuera un niño que no estuviera feliz se alejaría. En una ocasión ella me dijo que gritó a Mario y él se asustó. Yo le dije que en eso hay que tener paciencia: si rompió pues se compra, si ensució, pues se limpia, después del cumpleaños de Mario quedó mucho desorden y arreglé en media hora. Uno con esa mentalidad no. Hay que tener convicciones si dice hay que tener un negocio, lo montamos si no da, pues no dio, se monta otro y así, pero no con el miedo de que ay estoy trabajando en la casa porque es nuestra relación. Yo le decía a ella que está muy pegada al qué dirán y con las tías; yo no sé si se pusieron bravos conmigo, pero yo les dije: "nosotros ya estamos tomando nuestras decisiones y les pido que no regañen a Laura y si van a hacer criticas que sean constructivas y si no, pues no las hagan”.

T. Muy bien.

C. Y una tía me dijo si y la otra no sé si se puso brava. Entonces mi familia es Mario y Laura; si yo dejo que el resto de gente la ataque y la ataque, entonces ¿yo qué soy? Yo soy el papá de Mario, el compañero sentimental de Laura. Yo tengo mi genio, no digo groserías ni nada pero sí.

T. ¿Y fue parte de los motivos que tú encontraste para andar con Carlos?

L. Sí.

C. Y también son los motivos de ella, porque yo la veía achicopalada una vez en un paseo y yo le dije: yo tengo que hablar porque es nuestro bebé, porque juzgar no. Si nos van a regalar algo pues nos lo regalan, pero eso no les da derecho.

L. Lo que pasa es que la familia por parte de mi mamá tiene la tendencia de que son muy trabajadores para tener cosas, entonces el pensamiento de ellas es ese. Es entendible, entonces el concepto es darle a Mario lo mejor de lo mejor. Si por ejemplo Mario está comiendo tal cosa de tal marca, entonces que no, que tiene que ser esta, ellos no ven por fuera de ese rango. 
C. Yo creo que eso es también lo que le afecta. A veces se pone a llorar y no se puede controlar, llora y llora y llega a veces a lastimarse, entonces yo digo: necesitamos estar arriba.

T. ¿Y de qué manera te lastimas?

C. Fue una ocasión en que llegó a pegarse en la cabeza, porque se desespera; yo le digo: no, tranquila. Gracias a Dios ya tenemos la ayuda de mis padres; le decía: mira, tú ves unos niños sucios, a Mario en cambio todos lo adoran, todo es positivo hacia Mario y hacia lo que tiene. Pero las tías no...

Continúo ratificando el lugar central que ha ocupado la relación con Carlos en la vida de Laura, dada la comprensión y la mutua sensación de seguridad y pertenencia que se han propiciado. Aparecen creencias, valores y actitudes descalificadoras por parte de la familia extensa de ella que la frenan aún más en su validación en sus nuevos roles y contribuyen a lo que muy bien llaman su desesperación. Por esto paso a identificar sus fuentes de validación personal.

\section{Fuentes de validación de Laura}

T. Abora la gran pregunta para ti y no para que la respondas en este momento, sino para que lo pienses: ¿de quién te quieres hacer validar? Pues todos en verdad necesitamos validación, somos humanos y uno solo no puede. De pronto me equivoco, siempre necesitamos una retroalimentación de otros, pero uno tiene que elegir de quien, a esta altura; cuando uno es niño no puede, pero tú ya puedes elegir de quien quieres recibir validación y si en aras de darte algo eso te cuesta recibir una agresión, pues eso no sirve. Uno necesita saber con claridad para qué se relaciona con estas personas, porque uno no tiene por qué recibir mensajes que son fuertes o destructivos. Piénsalo ¿de quién te quieres validar a esta altura? Si a los 27 todavía necesitas que alguien te autorice para vivir, para ser tú misma o si al contrario ya estás a paz y salvo. Piénsalo para que me lo respondas ahorita. 
Esta confrontación refleja literalmente mi creencia en la libertad de cada quien de elegir a las personas cuya retroalimentación quiere recibir porque lo impulsan positivamente en función de lo que comprenden que uno desea y no en función de lo que a ellos les parece. Considero que esta es una fuente fundamental de autonomía que he encontrado como condición para asumir con libertad la vida adulta y que implica reposicionarse aún frente a las expectativas de los padres, para poder conducir la vida conforme al propio marco de referencia y no conforme al de ellos. En este momento puedo establecer una alianza transitoria con Carlos porque creo que si ella no asume su lugar de adulta y madre, la relación de pareja no será viable.

\section{Sobre la función de la terapia}

T. ¿Cómo se sienten aquí?

C. Estamos con un moderador externo porque con alguien como mi mamá uno no se siente con la confianza de decir todo lo que está pasando en la relación, porque muchas cosas que yo sé de ella que solo lo sé yo; es un espacio donde hay un moderador externo que es neutro, y son cosas que lo ponen a uno a reflexionar. Yo le dije: yo te apoyo, tú busca. Fue un poco lento, por lo mismo, yo soy el que la presiono, como con la ortodoncia, que las tías le dicen yo te pago no sé qué, yo le digo no dependamos de nadie, así, ta ta ta. Porque yo tuve una formación así. Sali del colegio salesiano Don Bosco, donde me enseñaron que no hay cosas imposibles sino personas incapaces; digamos donde yo estoy, inicié novato, supuestamente no sabia nada; no llegué diciendo que sabía lo uno y lo otro, por eso me mandan a viajar porque soy el que toma las medidas.

T. Y parece que tienes mucha iniciativa y si se te presenta una oportunidad seguramente la vas a aprovechar.

C. Exacto, por ejemplo boy yo debería estar en Yopal, pero hablé y listo, yo soy de esos y allá me tienen en cuenta en eso, que si sabe soldar, sí claro. La situación es dura pero siempre he sido el motor de ella; pero son esos lapsos y a veces no puedo estar todo el tiempo y no quiero que tú dependas de mí. 
T. Y además es mejor tener terapeuta externo a que el marido se le vuelva a uno el terapeuta. Sino la relación se cuelga de tal manera que terminas con dos niños, una niña y un niño, y si tú dejas de ser la esposa y todo se distorsiona.

L. Es cierto. Yo le cuento la mayoría de cosas, pero entonces él me aconseja según su criterio, mas no es el mismo de un psicólogo.

T. Claro, por más que sea un matrimonio. Hablo en esos términos porque así los veo; porque hablan como una pareja formaliza$d a, y$ es que eso no implica que cada uno renuncie al espacio de su realidad, porque si uno en vez de tener dos vasos de agua, como que mejor metamos todo en un vaso, entonces uno se diluye en el otro; eso si es grave y creo que por fortuna tienes un marido que piensa con claridad que cada uno es una persona; que necesitan estar juntos, pero preservando lo que cada uno es, porque entonces ¿̇uál es el aporte? Conversaré un poco con mis colegas y regreso.

Esta confrontación pretende reforzar el mensaje sobre la urgencia de que ella supere su posición de dependencia. Tengo dudas sobre qué tan fácil será para Laura recuperar su autonomía y por ello pienso en conocer, en una siguiente sesión, más de la imagen que tiene de sí misma para hacerle frente a la vida. Anuncio metafóricamente el riesgo de que ella se diluya en la relación y el temor de él de que esto ocurra, porque si bien intento subrayar los asuntos capitalizables, no puedo ser absolutamente optimista ni desconocer las vulnerabilidades emocionales de Laura. El contraste entre la postura vital proactiva de Carlos y la temerosa y pasiva de ella, señalan aún más los puntos de quiebre de la relación.

\section{Intersesión}

J. Pues veo una estructura de pareja adecuada y protectora. Están ligados tanto al vínculo de pareja como al vínculo de padres y el muchacho comprende la situación de la chica. Me preocupa ella respecto a la queja de él que es válida y es que ella no se posiciona de una manera definitiva para empujar la vida y él defiende 
la autonomía de pareja. Pero como que no tienen el espacio de pareja con limites propios, independiente de los límites de la familia.

T. Pero ya están en esos planes; se va a vivir a la casa del suegro, pero parece que es una persona que no aporta, más bien frena; se irán a la casa donde ella vive con el papá.

J. Ese es un paso importante. De ella me sigue preocupando un poco la estructura emocional que tiene, demanda demasiado reconocimiento para su edad, quedó noqueada después de la muerte de la madre, no sé si antes era distinta, pero está choqueada con la vida y la veo baja.

T. No sé si está pidiendo demasiado reconocimiento, porque personalmente pienso que cuando alguien lo pide debe ser porque lo necesita y no soy quien para calificar su necesidad. Creo que las necesidades no son parametrizables. Me detengo ahi porque quiero validar, connotar positivamente y quizá exagerar su necesidad de reconocimiento, precisamente porque lo que percibo es que si es cierto que la muerte de la mamá la afectó tanto, abora con su maternidad quizá se activó esa falta de mamá, porque al menos según la práctica social predominante, cuando una mujer es madre por primera vez, la persona que la acompaña es la mamá. Es verdad, por lo que he visto por terceras personas, que el entorno médico asusta a las mujeres, las hace sentir ineficaces, les mandan personas que les enseñen a amamantar, a bañar al niño. En aras de prevenir, se puede volver un procedimiento muy invalidante, como si no fuera un hecho natural. Por eso creo que mi última intervención era en ese sentido y en consonancia con lo que él decía, de haber tomado la iniciativa de parar a las tías que la criticaban y que ella remata diciendo que tienen una versión de la vida distinta a la suya. Pero ella se siente sola. Es verdad que no se habla de la soledad de las mujeres recién madres, pero es un momento de gran soledad; y si ella ya estaba fragilizada, le cae el embarazo aun planificando, queda sola con un abuelo que la critica. 
J. Si, la impresión que tengo es que la pauta de la familia ha sido un poco descalificadora. Contrastante con lo del chico. Me gustó que aclarara que la deja autónoma para actuar porque si no es asi él empieza a sobreprotegerla y sería un riesgo.

A. Yo creo que el vínculo de esta pareja puede ser muy reparador para ella, en el sentido de que los otros la corrigen continuamente y ella busca como corregirse para ser una buena madre; $y$ si esta es la pauta, nunca para ellos va a ser una buena madre.

T. Más aún si sigue pretendiendo validarse en ese reconocimiento exterior como madre que veo como una práctica social muy fuerte. Porque las mamás llegan a cualquier lugar con el bebé y todo el mundo los evalúa, si está grande, si está gordo, si come bien, etc. parece que en realidad Laura vive en un ambiente de una gran escasez emocional y por lo tanto el valor del apoyo de Carlos se magnifica.

A. Sí, porque le reconoce mucho eso y le ha ayudado a poner límites sanos. Creo que él tiene much a claridad y esperanza en ellos como padres; porque yo soy tía, casi que mamá y eso no es nada fácil; uno se equivoca todos los días. Es una experiencia que le ayuda a reivindicarse con lo que tú dices, de escoger las voces por las que quiero ser validada. ¿Qué expectativas tendrá cada uno de su pareja?

T. No me gustaría introducir esa idea en esta pareja porque ellos no la han mencionado y me temo que llevaría a cristalizarlos más en el rol social, que a ofrecerles un acompañamiento a lo que están viviendo hoy. Como él no puede venir y ella quiere trabajar más en ella misma, le voy a dar una estrategia que uso mucho y es que haga una biografía con pocas fotos para releer la historia y reubicar los personajes de su vida, justamente para poder trabajar en la imagen que tiene de si y actualizarla y a él lo llamamos luego. Tal vez les daré una tarea conjunta para que hablen de cómo quieren que sea la organización de su vida ahora que van a convivir. 
Este diálogo no requiere mayores comentarios pues ahí aparece en forma bastante explícita mi punto de vista. No obstante, debo señalar mi recelo de incorporar en la sesión nominalizaciones como la de "expectativas", cuando son contenidos que no han salido del marco de referencia de los consultantes y que percibo que los sacarán de la dimensión emocional que ha prevalecido en el clima de la sesión y desde donde describen sus dificultades.

\section{Cierre}

T. Bueno mis colegas los mandan felicitar porque hacen una pareja armónica; tienen un potencial en pareja positivo; además los felicitan porque hayan decidido convivir. Sería interesante si hacen un pequeño ritual para iniciar la convivencia.

L. Sí, lo habia pensado.

T. A mi eso me parece importante.

C. Sí, claro.

T. Que marque una diferencia que además sea un referente para ustedes. Como que tal día consolidamos nuestra unión.

C. Sí, toca de una vez o si no se embolata (risa).

T. Sí, es importante. Por otra parte les pediríamos que hicieran un par de tareas: una para los dos, teniendo en cuenta que vamos a verte sola una o dos veces antes de invitarlos de nuevo juntos; la tarea implica que no necesariamente el día del ritual, sino cuando quieran, hablen sobre los acuerdos de convivencia, porque a veces uno en la vida da por hecho muchas cosas. Cómo quieren organizar los tiempos juntos, con el niño, con la familia, economía, diversión. Supongo que cambiará el ritmo de la vida sexual, entonces para que lo hablen, porque hacer acuerdos genera un piso de tranquilidad. Para ti Laura, es una tarea con la intención de que saquemos de tu historia lo mejor y la limpiemos. Como cuando uno va de viaje y abre la maleta y dice: "uy no, esto yo para qué lo guardo". Te pediría que trajeras tu biografía en fotos; elige las que consideres representativas 
por alguna razón. Dentro de eso que acuerden, expliciten también lo que cada uno necesite del otro en concreto y que el otro también diga si lo puede hacer o no lo puede hacer. Nos agrada mucho trabajar con ustedes para que consoliden su edificio.

C. Gracias por esa ayuda.

T. Más adelante nos gustaría que vinieran con el niño.

L. Sí, claro.

T. Bueno, mucha suerte.

Salgo con la sensación de que fue una sesión muy intensa y reveladora. Aunque tengo dudas sobre la viabilidad de la convivencia por las diferentes dificultades que se evidenciaron, elijo reforzar esa idea y darles la tarea de que conversen sobre las condiciones mínimas para compartir la vida, pues si lo hacen ya estarán aproximándose a cumplir el objetivo de aclarar la naturaleza de la relación. En general, cuando las parejas en terapia se debaten en este tipo de dilemas, aplico la estrategia de invitarlos a acercarse a una de las polaridades, de consolidación o de ruptura, no porque yo tenga de antemano alguna preferencia, sino porque con la experiencia he observado que inclinarse hacia un extremo por insinuación del terapeuta se convierte en una especie de ensayo de lo que han dudado vivir, con lo cual se amplifican las auténticas motivaciones que sostendrán las decisiones más definitivas.

La tarea de hacer la biografía en fotos es un modo de acudir a la historia para ayudar a los consultantes a rescatar recursos, reeditar experiencias y reconsiderar las relaciones con personas significativas, además de permitir al terapeuta acercarse al contexto de cada persona en forma más vívida y específica. Como se verá en la siguiente sesión, se trata de conversar con los personajes de las fotos y de facilitar la metamirada del consultante sobre su historia, más que tener apenas un relato anecdótico. Considero que puede ser un ejercicio muy productivo para Laura porque no solo podremos identificar capacidades sino también elaborar la relación y la desaparición prematura de la madre, con el fin de perfilar mejor su propia imagen. 


\section{Tercera sesión}

Quince días después. Asiste Laura sola.

\section{Dudas sobre la convivencia de la pareja}

T. Bueno, ¿qué novedades hay?

L. Pues hemos estado hablando bastante con Carlos de lo de vivir juntos, hay veces que cambiamos de parecer otras que si queremos, pero hay ciertas cosas que están fallando que nos hacen dudar. Entonces estamos mirando si será la mejor decisión o si esperamos un tiempo.

T. ¿Y qué es lo que está fallando?

L. Pues por un lado el traslado hasta mi casa le genera inconvenientes con el horario del trabajo, es bastante lejos, el trasporte es complicado, esa es una de las cosas; ya por otro lado tenemos ciertas peleas, él a veces como que duda por eso, de pronto piensa que no sepa manejar eso después, se siente incómodo.

T. ¿Y a qué se refieren esas diferencias?

L. Es lo que te contábamos: a veces yo tengo una rutina con Mario $y$ él hace algo diferente, entonces nos molestamos y por otro lado he conversado con mi papá y no lo siento del todo convencido, pues dice que es necesario, que es una ayuda para mí, pero a veces siento que está dudoso. Hablé con él y le pregunté qué opinaba y decía que no lo conoce muy bien; aunque yo llevo seis años con él, pero mi papá no ha estado muy involucrado. Digamos que conoció a la familia de Carlos hace dos años, porque al inicio de mi relación yo vivía con mi tía, pero mi papá era muy reacio. Entonces le pregunté y me dijo que no sabia, que sentía que quizá no encajaría mucho.

T. ¿Y qué le hace pensar que no va a encajar?

L. La familia de Carlos, tiende a hacer cosas en la rutina que mi papá maneja muy distintas.

T. Por ejemplo.

L. A mi papá le gusta comer cierta comida y Carlos es completamente diferente; le gusta preparar cosas muy sanas. No sé, de 
pronto no entiendo mucho el tema, porque no me lo ha explicado bien, pero siento que no está convencido. Por otro lado me comentó que había hablado con mi hermana; ella tiene ganas de que mi papá se vaya a España y la posición de mi hermana es que mi papá sea un papá para Mario; yo hablo con ella y le digo que no, que es Carlos. Mi papá es mi papá, no el de Mario; ella no lo entiende, he visto que hablan entre ellos y no me comentan nada.

T. Me da la impresión otra vez de que hay mucha gente manejando los hilos de tu vida.

L. Sí, y mi hermana cree que si Carlos se va para la casa, mi papá lo va a mantener. Igual yo le he dicho a mi papá: Carlos está trabajando, a Mario nunca le hace nada falta porque Carlos responde y no veo porque eso afecte.

T. ¿Y la casa es de quién?

L. Pues nosotros vivimos en arriendo, mi papá es el responsable.

T. ¿Pero esa idea de llevarse a tu papá a España se puede concretar en qué tiempo?

L. Pues ella hace cinco meses nos comentó que tenía muchas ganas; ella allá ya tiene la ciudadanía y puede pedir a sus hijos o padres; en este caso a mi papá le ha dicho que quiere que se vaya para allá porque ya tiene mucho trámite adelantado. Pero mi papá es el que no quiere; dice que no, estoy con Laura, yo tengo que todavía responder por ella, siente que todavía tiene esa responsabilidad conmigo, piensa en Mario.

T. O sea un poco tú y tu papá están en la situación de saber qué sigue en la vida. ¿Y tu papá sabe que vienes acá?

L. Sí.

T. Piensas que si lo invitáramos él vendría, sería importante porque con esto que nos cuentas, la presencia de los dos sería muy importante para ayudarles a esclarecer el panorama y asi los dos van desligando las responsabilidades.

L. Exacto, para poder también dialogar con mi papá este tipo de cosas. 
La pareja trabajó en la tarea de concretar las condiciones de convivencia y se evidencian allí diversos tipos de dificultades: económicas, logísticas, discrepancias en la cotidianidad de la crianza del niño, problemas en el manejo de los conflictos de pareja, recelos del padre y la hermana de Laura hacia la capacidad económica de Carlos y diferencias en las subculturas familiares. A pesar de las dudas emergentes, estos movimientos hacia la concreción de las posibilidades de la relación van despejando el panorama vincular y de la autonomía de Laura. Resulta muy significativo que el papel pasivo que se venía dibujando del padre de Laura empieza a cambiar y por ello su presencia en la terapia constituye un importante recurso de cambio. Pareciera que Laura se mueve activamente hacia el esclarecimiento de todas sus relaciones, lo cual indicaría un avance importante en su proceso de posicionamiento y diferenciación como persona. Por eso me detengo en la exploración más específica de las relaciones con los miembros de su familia.

\section{Relación de Laura con su hermana}

T. ¿Y tú qué tanto hablas con ella?

L. La relación entre ella y yo... pues desde pequeñas fuimos muy peleonas, cuando crecimos nos entendimos pero seguíamos peleando.

T. ¿Y por qué razón?

L. Ella decía mentiras y me ponía a mí a sacarla de las mentiritas de adolescencia: que voy a salir con tal pero no le diga a nadie; mi mamá se enteraba y mi hermana creía que yo era la sapa. Ya luego bubo un gran conflicto cuando decidí irme a vivir con mi tía, que fue al año de que mi mamá falleciera; ella se molestó mucho, no lo entendia, se puso brava.

T. O sea ella quiere organizarte la vida, pero en realidad no conoce como son tus deseos ni circunstancias...

L. Sí, y cuando vivía con mi tía ella se fue a España y la relación quedó en esos términos; cuando se fue sentí un poco de alivio; sin embargo eso hizo que mejorara la relación; desde el 2008 
cuando se fue, ha venido dos veces. La última vez que vino fue bueno, fue una relación muy bonita.

T. ¿Eso fue hace cuánto?

L. En 2012.

T. Antes de que naciera el niño.

L. Exactamente y cuando le cuento que estoy en embarazo se molesta un poco, digamos que a partir de abi me dice que me quiere colaborar pero no darme todo. El pensamiento de ella es como lo que te cuento con mi tía, que es como querer ayudar, pero en el mismo momento es también una crítica.

T. Una ayuda condicionada...

L. De pronto, pues no tanto como mi tía, es más comprensiva, es de ayuda y diálogo, pero la relación es esa. Entonces tampoco le cuento cosas personales.

T. Claro, tienes recelo de que juzgue, te censure...

L. En el momento que le conté cómo me sentía en enero, el niño estaba decaído, ella se preocupó, también me dijo que viniera al psicólogo, pero que hablemos seguido y de cosas personales no tanto.

Esta descripción confirma una vez más la fragilidad de la vinculación familiar y deja ver un posible paso de la rivalidad fraterna a una pretendida ubicación de la hermana en un rol parental que Laura rehúye con relativo éxito, pues al irse a vivir con su tía encuentra también allí una relación complementaria y vertical. Todo eso sigue permitiendo comprender el largo proceso de gestación del self y del malestar actual de Laura y de cómo su relación de pareja estuvo desde el principio sobrecargada por las carencias afectivas en su familia de origen. No obstante esa historia, parece que las experiencias de Laura están obligando a su padre y su hermana a rehacer los vínculos bajo nuevas condiciones, después de superar las situaciones pendientes alrededor de la vida familiar, sobre todo después de la muerte de la madre, aunque ya han pasado nueve años de su deceso. Todo esto me lleva a puntualizar justamente cómo es el self que Laura cultiva en ese nicho. 


\section{Cómo Laura se vive a sí misma}

T. Entonces viendo ese panorama a tu alrededor ¿cómo te sientes? ¿De qué te das cuenta? Y ¿qué postura quisieras tener?

L. Pues hay momentos que le hallo la razón a ella y a mi familia en ciertas cosas, como en lo que me pueda deparar la vida. Les angustia que no tenga un sustento propio, eso les afecta mucho, como que dependa de Carlos. En parte lo entiendo, pero lo que quisiera por momentos, que me comprendieran, es que para mí no ha sido fácil organizarme.

T. O sea una presión más que te pesa. Porque escuchándote da la sensación de que la gente no comprende bien lo que tú vives, pues Carlos te presiona por unas cosas y cada uno de los que mencionas te presiona por otras y eso demanda una cantidad de exigencias; cada quien te jala para un lado.

L. Sí, actualmente siento que cada uno quiere algo de mí y además Mario todo el tiempo.

T. Pues veinticuatro horas, al no tener quien te ayude con él, ¿qué alternativa tienes?

L. Mi papá me ayuda, pero no de tiempo completo.

Da la sensación de que Laura empieza a tener una comprensión contextual de su malestar, razón por la cual podría ser cuestionada o descalificada en su medio, pues representaría para los demás la exigencia de identificar su participación en estas dificultades que quizá se venían atribuyendo hasta el momento, principalmente al embarazo inesperado. Esta relectura sirve para aligerar sus sentimientos de culpa y de inadecuación y para permitirle visualizarse como alguien con capacidad de gestión de su vida y de renegociación de su lugar en su nicho de pertenencia. Considero que este es un buen momento dentro de la sesión para fundamentar en su historia la forma como los hilos de su vida se fueron tejiendo hasta llega a este punto. 


\section{Biografía en fotos}

\section{Relación con la madre}

T. Habiamos hablado de que íbamos a ver tu biografía en fotos, entonces arranquemos.

L. Sí, traje también en el celular.

T. Puedes ubicarlas en orden cronológico. Se trata de que me vayas contando quienes son esas personas.

L. Acá, ella es mi mamá, yo tendría un año y medio. Esa foto me gusta mucho, porque las fotos que tengo con mi mamá son más que todo así, pequeña; ya después de los 13 casi no tengo fotos con ella.

T. Háblame de esa bebé.

L. Cuando veo la foto pienso mucho en Mario, es parecido. Veo aquel momento en que mi hermana me contó que mi mamá tuvo que dejarme desde muy pequeña en un jardín porque el trabajo era muy exigente. A veces cuando veo esta foto me acuerdo de Mario porque varias personas me dicen que él tiene una mirada triste, cómo sería yo...

T. ¿En qué se ocupaba tu mamá?

L. Secretaria en una cooperativa en el centro y el jardín quedaba cerca; yo allá estaba con mi hermana y un primo.

T. Y hacia esa niña que ves ahí ¿qué sientes?

L. Cuando me veo así chiquita, me da melancolía; relaciono lo que me dicen de Mario con lo que veo también de mí. No sé si sea una sola sensación, pero veo que estaba bastante tiempo sola y más grandecita pasé bastante tiempo solita o con otras personas diferentes.

T. ¿YY hacia tu mamá?

L. Pues mira que casi siempre la veía seria, era una persona poco expresiva, sonreía pero no era muy expresiva, ni de alegría; era más bien reservada, son pocos los momentos que la vi sonriendo; en fotos no.

T. ¿Tú piensas que ella la pasaba bien en la vida o cómo le iba? 
L. Yo cuando era pequeña le preguntaba que si estaba brava. Mi abuelo siempre fue duro con ellas, era de temperamento fuerte, no lo conocí y mi papá me contó que ella había sufrido tres abortos, que se habia sentido culpable, porque habian sido provocados y uno si natural. Entonces a veces siento que eso marcó a mi mamá; nunca tuve la oportunidad de hablarlo, pero creo que la marcó. La primera vez que le dio cáncer era de útero y me decía mi papá que podía haber relación; desde que mi papá me contó eso, lo he tenido en la mente.

T. ¿Y de qué manera lo tienes en la cabeza?

L. Pues digamos, siento que mi mamá sufrió mucho por eso.

T. Además eran unos hechos muy delicados para estar hablando de ello.

L. Exacto y pues yo siempre dije: "me voy a cuidar". Después de lo que le pasó y además haber fallecido por el cáncer, dije: no puede ser, tengo que cuidarme. Por eso cuando quedo embarazada de Mario, nunca estuvo en mi mente hacerlo... Entonces siempre tuve eso en mi cabeza; respeto a quien lo ha hecho, es respetable, pero siento que es algo que puede marcar, a mi mamá la afectó.

T. Tú eras la única opción de ella para ser madre, porque los abortos fueron previos...

L. Si y también me acuerdo que mi papá me contaba que cuando estaban en mi embarazo, él quería que fuera un niño y tenía esa ilusión y cuando nací, de pronto como que se sintió desilusionado.

T. ¿No le preguntaste como habia hecho para ilusionarse después?

L. No, nunca lo hablé con él. Pero eso uno lo tiene abi en la cabe$z a$.

T. Ah, qué interesante. ¿Y cómo te sientes hablando de esto?

L. Pues me da un poquito de tristeza, pensar que no sé cómo fue la situación en que mi mamá me tuvo, no sé en qué circunstancias estaban, pero por momentos siento que llegué en el momento que no era, aunque no sé... 
Este relato de hechos tan densos refuerza la comprensión de sus sentimientos de profunda tristeza, desamparo y quizá de lo que Erick Erickson llamó carencia de confianza básica, pues sus palabras conducen a pensar que ni aún por parte de su madre sintió validada su existencia. El claro recuerdo de una madre poco afectuosa y la sensación de soledad reflejarían el contexto propicio para la emergencia de un self que siente que no le han dado un lugar en el mundo. También es posible entender la pesada significación de su inesperado embarazo y los temores magnificados por las terribles consecuencias vividas por la madre al eludir el ejercicio de la maternidad. Su identificación con su hijo puede ser una herramienta positiva y reparadora, que quizá le sea útil para reconstruir su historia y sus creencias alrededor del rol materno y de la generación de vínculos afectivos más fuertes con los hijos. Aun cuando el relato abre varias rutas para continuar el proceso, elijo seguir ahondando en sus experiencias de validación como foco central de la terapia y del cambio, sin desconocer el impacto que todavía pueden seguir teniendo en su vida las carencias afectivas de su infancia. Me queda la sensación de la madre como una mujer un poco atormentada por la culpa, con una incierta satisfacción conyugal y vital y en apariencia con dificultades para establecer una vinculación emocional adecuada con sus hijas. Da la impresión de que Laura comprende la situación de la madre y no la culpa, pero todavía resiente su ausencia afectiva.

\section{Historia de reconocimiento, protección y validación}

T. Y si miras los otros momentos de tu vida, ¿cuál sería el momento en que te sentías mejor acompañada?

L. En este momento mi mamá ya estaba bastante enferma: fue mi grado del colegio. (Mirando otra foto). Siento que fue en esa edad, era la primera comunión de mi hermana yo tendría cinco años.

T. ¿Y te acuerdas de esa época?

L. Sí, sí me acuerdo.

T. ¿Cómo era tu vida? 
L. Viviamos en este apartamento, sentía que no pasaba mucho tiempo mi mamá conmigo pero había una señora que me cuidaba, teníamos unos vecinos que tienen un hijo de mi edad, pasábamos mucho tiempo con él, tenía amigos. De mis papás recuerdo que trabajaban mucho. Ahi ya estaba el negocio, entre semana mi hermana estaba en patinaje y yo la acompañaba y mi papá era muy ausente en esas cosas. Él siempre fue más de trabajo, de pronto el fin de semana nos reuniamos, pero no nos acompañaba a clases ni a cosas del colegio. Siempre fue mi mamá.

T. Bueno ¿y qué recuerdas que tus padres? ¿Te reconocerían? ¿Te halagarian?

L. Pues no sé, porque después de que mi hermana entró a patinaje, yo entré a natación; iba con una prima y mi mamá siempre quiso que yo aprendiera a nadar, me veía nadadora. Ella no era muy expresiva, entonces no recuerdo pues realmente unas felicitaciones, que me dijera: "qué bonito te quedó esto", o "mira qué chévere”.

T. Y tu papá... ¿̇menos?

L. Menos, él estaba en su cuento. Sí recuerdo que fue lo contrario a mí, porque cuando avancé en campeonatos en natación...

T. ¿Avanzaste bastante?

L. Sí, desde chiquitica hasta los dieciséis. Entré a Compensar pero no alcancé a la liga de Bogotá.

T. ¿Por qué razón?

L. Hubo un momento en que me aburrí era poco el tiempo que uno tenía para compartir con amiguitos, empecé a agotarme, pero siempre me dio miedo decirle a mi mamá eso, no fui capaz de contarle y los últimos tres años bajé el nivel y el colegio era más pesado.

T. ¿Dónde era que estudiabas?

L. En las esclavas del Sagrado Corazón de Jesús. Entonces empezó a tornarse muy pesado, pero yo no le decía a mi mamá ni mi papá, pero los entrenadores sí me decían. Pero ya llegó el punto en que me di cuenta que ya no quería competir; además 
me di cuenta que había que pagar para pertenecer al grupo; no éramos afiliados a Compensar y era muy caro; en ese momento no estaba bien la situación económica en la casa y se tomó la decisión de que tenía que retirarme. Quedé abí. Siempre quise llegar más allá, pero al mismo tiempo sentía que tampoco tenía el físico para lograrlo; la mayoría son altas, delgadas y yo no tenía esa contextura; sentía que no iba a poder. Entonces cuando me dijeron que no se podía, dije bueno. Pero sin embargo me afectó mucho, porque fue mucho tiempo y ahi estaba mi vida social; además fue un cambio en mi vida por los horarios y sentir libres las horas en que nadaba era rarísimo. En definitiva mi mamá no se dio cuenta que yo estaba desanimada y la que me acompañaba era mi abuelita; ella me cuidó muchísimo.

T. ¿Materna?

L. Sí, siempre estuvo conmigo, yo tiendo a ser la nieta preferida.

T. ¿Y tu abuelita sí te felicitaba, te reconocía?

L. Sí, pues a pesar de que ella cuando iba no entendía mucho, llevaba sus libros, pero siempre estaba pendiente de mí, mi entrenador estaba también pendiente de mi abuelita.

T. ¿Y tu entrenador qué pensaba de ti? ¿Qué te decía?

L. Pues él siempre me decía que yo tenía talento para eso, pero me preguntaba por qué me desanimaba tanto, entonces me incentivaba. No sé, llegó un punto que me aburrí de la monotonía.

En vista de la falta de reconocimiento por parte de sus padres pasó a otros contextos y evidentemente se encuentran sus realizaciones como estudiante y como deportista, aunque con muy poco eco al respecto en su familia. El estímulo del profesor de natación y de la abuela tiene efectos tenues en la imagen de Laura, quien además se siente en desventaja física y económica frente a sus compañeras y por limitaciones de dinero deja el grupo de entrenamiento deportivo que le ofrecía contención y red social. Esta experiencia agridulce sigue infortunadamente sumando a su falta de vivencias donde fortaleciera su self y aumenta la sombra de negatividad en su mundo subjetivo. 


\section{Hacia la adopción de sí misma}

T. Ahora entiendo esta foto, ¿̇cuántos años tienes?

L. Como diez años.

T. Viendo a esa niña, y si fueras la mamá de esa niña y conociendo a esa niña ¿qué te gustaría decirle para que ella tuviera un mejor concepto de sí misma?

L. Pues yo creo que para empezar, la acompañaría más; si yo tuviera una hija en esa posición estaría más pendiente de ella, en los momentos más importantes, hablarle más, expresarle mi apoyo...

T. ¿Y qué te hubiera gustado que esa niña escuchara en esos términos?

L. "Lo estás haciendo bien", "mira como nadaste de bonito", "me siento orgullosa de ti", "lo estás haciendo muy bien", aunque de pronto no sea cierto, pero sí...

T. Bueno, aunque ya mantener un ritmo de entrenamiento en el colegio, no todos los niños tienen ese tren...

L. Y eso me ayudó en la responsabilidad del colegio; cuando salí me bajó el rendimiento del colegio, porque estando con las dos cosas era muy organizada y eso me lo enseñó también mi mamá, siempre lo tuve en mi mente.

T. Y tú que conoces a esta niña ¿en qué de ella confías?

L. Desde niña es una personita carismática, amable, siempre dispuesta a colaborar, siempre he sido una persona amable con la gente.

T. Eres muy dulce además...

L. Sí, me lo dicen, y eso es lo que más recalco.

T. Y en términos de sus capacidades, ¿por qué cosas la felicitarías?

L. Lo responsable, lo inteligente, desde chiquita atenta a lo que me enseñaban en el colegio.

T. Aprendias rápidamente. Igual la inteligencia se conserva toda la vida...

L. (Risa) Pues yo resaltaría eso, por lo mismo, por mantener esas dos responsabilidades, colegio y natación. 
T. ¿En el colegio en qué te destacabas?

L. Literatura, artes, español, me iba muy bien en biología e historia.

T. ¿Tuviste alguna distinción?

T. En algún momento creo que en esa parte de historia y lenguaje, pues no fue seguido, pero sí. Hubo otras que recuerdo más por responsabilidad, disciplina.

T. ¿Y cómo te sientes ahora presentándonos a esta Laura?

L. Hace mucho no lo analizaba, creo que no lo habia hecho. Es como recordarme.

T. Pues porque esa es la socia que va contigo en la vida. ¿Cómo te sientes con esa socia?

L. Quisiera mejorar, pensando en mi niñez, hubiera querido cambiar ciertas cosas, recuerdo todo muy bonito, igual era alegre, de pronto no de muchos amigos, pero si estaba contenta y pasaba mucho con mi abuelita.

T. ¿Ella vive aún?

L. Sí, tiene setenta y ocho años y sufre de Alzheimer. No se acuerda de los nombres de nadie.

T. ¿A ti te reconoce?

L. Sí, pero no se acuerda el nombre en el momento. Sí nos causa curiosidad que se acuerda de Mario. Ya no la veo tan seguido porque está a cargo de una de mis tías y con ella la relación es distante; pero sí la recuerdo y le tengo cariño.

T. Y si Mario escuchara toda esta historia y supiera que eres todo esto ¿Cómo te sentirías?

L. Contenta, siento que tiene mucho parecido a mí, no solo físico sino en mi personalidad; ciertas cosas las noto similares y de pronto si lo viera diría: "uy tienes razón”, pero lo que no me gustaría que viera es esa parte de mí que ha sido tímida, insegura.

T. ¿Pero eso en qué momento comenzó? Porque hasta ahí no está presente...

L. Más que todo cuando empecé a nadar, siempre me sentí es desventaja de los demás, por lo mismo; físicamente eran altas, delgada y nadaban más rápido; siempre me sentí inferior y siempre 
me he sentido tímida; ya no tanto, pero antes sí; más que nada lo recuerdo en natación. Mi entrenador me incitaba a compartir con los compañeros, pero realmente no sé por qué terminé siendo así; no soy amiguera, no sé desde qué momento. Algo que pienso es que Mario, no digo que deba ser mi polo opuesto, pero si incentivarlo. Lo que me han dicho adónde lo llevo es que debe compartir más, no que se sienta obligado, pero sí incentivado. Eso sí lo tengo presente y me preocupa.

T. Pero entonces ¿qué de ti te gusta que los demás conozcamos?

L. Antes de que falleciera mi mamá, me sentía segura de lo que quería estudiar, de mi talento para eso y mi familia lo notó; igual en natación; eso sí me lo felicitaba mi familia y siempre me vieron responsable, disciplinada, juiciosa. Siento que la gente ve eso en mi y eso fue antes de que ella se enfermara y a mi me gusta que me reconozcan eso. Pero cuando fallece mi mamá, me dejé de sentir merecedora, fallé mucho en muchas cosas de la universidad que dejé tiradas.

T. Se te refundió esta Laura...

L. Exacto.

T. ¿Cómo te sientes?

L. Bien, para recordar quien soy.

Este diálogo refleja los resultados alentadores del ejercicio al reencontrar en la historia la imagen positiva de sí. Se percibe más fuerza en sus afirmaciones y en el reconocimiento de sus fortalezas, sin desconocer las vulnerabilidades. Lo más importante es quizá la posibilidad de observarse a sí misma con cierta distancia y darse cuenta de que tiene cómo convivir consigo misma como una "socia" capaz de organizar sus actividades y su vida. Acudo a esas experiencias positivas vividas alrededor de sí misma porque encuentro que favorecen la apropiación de sí, más que el reconocimiento externo, por demás escaso en su vida. Por otra parte, el ejercicio favorece el darse cuenta de la construcción del self como un proceso interaccional en el tiempo y ello contribuye a relativizar las definiciones anquilosantes acerca de sí misma. 


\section{Intersesión}

J. Bueno hemos podido percibir que se ha ido reconstruyendo la historia a partir del relato; tiene que ver con su identidad como ser humano, porque en cierta medida su dilema está en moverse en los dos polos: el negativo y el positivo. Pero confrontar la parte negativa de su historia le ha permitido reconciliarse con sus recursos. Notaba en su historia siempre la expectativa de connotación positiva, siempre está esperando, esperando, porque al comienzo era como que no me esperaban mis papás, era negativa de entrada y ahí empezó también con su físico, con su belleza y se está reconstruyendo, es interesante.

Y. A mí me gustó mucho la actividad porque vi el cambio al hablar de sí misma con respecto al comienzo, donde ella misma nota sus propios recursos; fue una connotación positiva de sí misma.

J. Sí, porque lo que veíamos era la paradoja de qué pasaría si el terapeuta la animara, qué es lo que espera, quizá no tanto que la animen sino un proceso autorreferencial de reconocimiento. Vimos que cambió el tono emocional a mitad de la sesión y su sentimiento fue cambiando respecto a su propia actitud.

T. Pensaría que hay que seguir con la adolescencia porque lo que llevamos es hasta cuando sale del colegio y lo que ella decía al final es que la parte más oscura es cuando muere la mamá y se desorienta y no sé si para agilidad la citamos con el papá.

J. Sí, porque con ambos se podría reconfigurar la historia de la muerte de la madre, porque tienen embrollos míticos; descongestionar al padre frente a ella es descongestionarla a ella frente al padre. La historia de la familia se reconstruye.

T. Y que la validen para que se puedan soltar.

La reconstrucción de la historia sobre fotos es la oportunidad para que Laura se dé cuenta de que ahora ella puede filtrar y activar las fuentes de validación para sí misma, pues ciertamente hasta el momento pareciera que ha asumido esta postura expectante de un permiso familiar y social para ser ella misma. 


\section{Cierre}

T. Bueno, pues nos parece muy interesante conocer tu historia y poder identificar los pilares donde has organizado tu vida. Ahora queremos entrar a la etapa difícil, justamente puede ser muy importante que eso lo abordemos también con tu papá; así la versión de ambos los va a enriquecer para continuar en este proceso de ayudarte a capitalizar todos tus recursos. Rescatarte de una zona que todavía te pesa y hay que trascender. La idea que me he hecho es que volviste a quedar en la soledad, porque pareciera que a tu alrededor no ha habido una pertenencia tan explícita, como que están ahípero no se nota y no es tan activa esa presencia de otros para que refuerce lo necesario para convencerte de lo que si eres. Algo muy importante, para que tengas en cuenta es que ahora ¿quién es la mamá de Laura?

L. Pues en este momento... Nadie, no sé, he tenido varias figuras maternas incluso desde antes, siempre mi tía estuvo ahí, mi hermana también.

T. En otras palabras ¿a quién le corresponde auto protegerte?

L. A mi misma.

T. Todo lo que venga por cuenta de los demás es ganancia. Me gustaría que te vayas con ese pensamiento para que puedas darte el reconocimiento en todo lo que haces porque es la fuente más real de lo que tienes. Claro, uno necesita retroalimentación de los demás, pero la fuente que está siempre con uno es uno mismo. Te esperaríamos con tu papá en la próxima sesión.

L. En ocho días.

T. Bueno, das la impresión de estar más tranquila, más a cargo de ti, nos vemos entonces.

L. Sí, señora.

El trabajo realizado durante la sesión se sintetiza en la noción de autoprotección, con base en la cual conceptual y clínicamente he visto que se rompen las pautas de pasiva espera de validación por parte de figuras significativas que ya no están o que si están siguen siendo poco 
generosas en el reconocimiento, bien sea por razones idiosincráticas de la cultura o de la persona, o porque hay pendientes en la elaboración de la historia relacional que por diversas razones no se pueden abordar en forma directa. Entre otras razones, porque con frecuencia la historia emocional de cada sujeto no se corresponde con la historia factual del grupo familiar, de modo que si se confrontan hechos pasados entre miembros de la familia puede correrse el riesgo de una nueva descalificación hacia el que reclama, pues los demás pueden creer auténticamente que han dado y hecho lo mejor, lo cual no se puede negar, porque más bien refleja las limitaciones humanas de las figuras significativas, principalmente de los padres y por tanto no queda más que la aceptación y el perdón. Pudiera pensarse que en el caso de Laura ahondar en estos procesos sería una forma de reforzar su cambio, pero esa queda como una carta a jugar si se identifica posteriormente esa necesidad.

\section{Cuarta sesión}

Ocho días después. Asiste Laura con el padre².

\section{Acogida al padre y sentido de su presencia en la sesión}

T. ¿Cómo le pareció la idea de que lo invitáramos aquí hoy?

PA. Bien, interesante la idea de ver cómo funciona y cómo están las cosas que han hecho aquí con Laura y miramos a ver en qué va todo.

T. A nosotros también nos interesa lo mismo: saber en qué va todo. ¿Y tú como has estado?

L. Bien, pues han pasado varias cosas esta semana.

T. ¿Que tu papá conoce?

L. No.

T. ¿Y quieres compartir con él o dividimos la sesión para conversar un poco los tres y luego hablamos a solas contigo?

L. Pues sí, en parte porque todavía no he querido comentarle nada a él.

2 PA, padre de Laura. L, Laura. T, Terapeuta. 
T. Ok, ya después entonces lo enterarás.

T. Pues nuestra intención de conocerlo, además de tener una retroalimentación de cómo va viendo usted a Laura, es también conocer de parte suya algunas ideas tanto acerca del presente como del futuro y algunas del pasado que nos puedan ayudar a comprender cómo fue que llegó a este punto de su vida y cómo continuar, por una parte, pero también entendiendo, que con el papá del niño, usted y el niño, son el núcleo más importante de Laura y que por supuesto lo que pasa con ella y lo que pasa con los demás está relacionado y les afecta mutuamente. Esta es nuestra intención. Y tal vez, para hacer más productiva su presencia acá, porque no es tan fácil venir hasta acá, sería interesante que hablemos de cómo son los proyectos de la familia, más que referirnos a la historia. ¿Cómo ven el presente y el futuro? ¿Cómo son los planes? Yo sé que usted tiene a su otra hija en España; he entendido que tiene un negocio de producción de mantequilla y que usted es una persona muy tranquila.

Este encuadre de la sesión busca darle un sentido contextual a la presencia del padre, de modo que sin desconocer los hechos pasados, se enfoca más hacia la proyección conjunta, teniendo en cuenta el objetivo de la terapia de incrementar la diferenciación y la autonomía de Laura, contando con las personas significativas de su vida y las posibilidades de su realidad. El anuncio que ella hace sobre eventos importantes que no le ha comunicado al padre me genera expectativa y en el momento me alerta sobre la necesidad de preservar su espacio terapéutico, razón por la cual ofrezco la posibilidad de hablar sobre esos temas sin el padre. Sin embargo, no descarto que una vez evaluada la apertura del padre, pueda hablarse junto con él, pues en las sesiones previas se ha evidenciado más bien la necesidad de que la comunicación sobre los asuntos que los afectan sea más fluida. 


\section{La historia del padre y su perspectiva sobre el futuro de la familia}

PA. Sí, está en lo correcto. Yo soy muy tranquilo en todo sentido, donde yo no hubiera sido tranquilo creo que mi vida habría sido un desastre; lo que pasa es que he tenido muchos altibajos en la vida; yo toda la vida he sido comerciante, tenía un negocio en Corabastos de Bogotá, tenía un punto de venta, pero debido al cambio que hubo en la ciudad al hacer la malla vial, la clientela se desapareció y uno como comerciante vive de los clientes. En la parte donde yo quedé, que es la última bodega hacia el sur, era muy concurrido porque vendían huevos, panelas y unos cuantos almacenes de grano y de dulces, pero debido a eso revolcaron casi toda la clientela de Corabastos y la gente se ausentó, se fue ausentando paulatinamente, terminamos solos.

T. ¿Y hasta cuándo tuvo el negocio?

PA. Eso fue hasta hace un año. Entonces afortunadamente yo habia aprendido a fabricar la mantequilla y me he dedicado a eso, pero no es lo mismo. Dejó de ingresar una cantidad de platica que nos daba el sustento y eso empeoró porque no pude cancelarle a Corabastos el local.

T. ¿Tenía su local?

PA. Si, tenía tres locales, pero se fueron yendo así con el tiempo; no pude venderlos en el momento preciso y ya después no valian nada, no daban nada. Es bien sabido por todos nosotros que las cosas entran por los ojos y una persona que iba allá y se paraba, se daba cuenta que eso realmente no funcionaba, no compraban; entonces me fue absorbiendo esa deuda con la corporación, ellos cobran abi un arriendo y hasta que no pude; me tocó entregarles y asi una cantidad de cositas que yo tenía. Nosotros quedamos relativamente en ese momento como para medio vivir, con dificultad; bueno démosle gracias a Dios que tenemos salud, que creo yo que es lo más importante que existe en la vida y que se trabaja, tengo mi experiencia.

T. ¿Y entonces dentro de ese panorama como qué sigue? 
PA. Dentro de ese panorama, mi proyecto es seguir con eso, seguir con eso que está muy difícil porque se ven muchas trabas del gobierno; segundo es muy complicado en este momento conseguir la materia prima porque las empresas grandes la absorben la materia prima al pequeño comerciante le dejan los rezagos; pero bueno, ahi nos mantenemos; entonces el proyecto, hasta que Dios me tenga con vida, es seguir con eso que es lo que sé hacer y mirar a ver si de pronto puedo impulsarlo en estos años. Aunque hay opciones de que me vaya para donde la otra hija, pero ya muy difícil porque al irme... no quisiera dejar a Laura desprotegida, al menos tiene el poco respaldo mio.

T. Bueno, no tan poco, ¿porque ustedes tienen una casa?

PA. No, en este momento no tengo nada. Todo lo perdí, todo me tocó dejarlo pagando a los proveedores, si... entonces tenemos muy poco capitalito ahípara negociarlo a ver si se compone eso y pueda volver a conseguir algo...

T. ¿O sea que tiene su corazón entre España y Bogotá? ¿O tiene por abi alguna otra cosa que lo hale aqui?

PA. No, no realmente, por lo único que me he quedado aqui y no he hecho el esfuerzo por irme es por Laura. Yo quiero verla bien a ella con su esposo, si es que van a mantener su relación, como todo papá que quisiera ver a sus hijos bien y si ellos están bien uno está bien. La otra china que tengo allá, pues ella se preocupa bastante por nosotros porque vio digamos el descenso que tuvimos en cuanto a comercialización y vive más bien preocupada, ella se mantiene en contacto con nosotros.

T. ¿O sea tú también tienes opciones de irte a España?

L. Pues ella en algún momento si... inclusive le hizo la propuesta a Carlos, porque el esposo de mi hermana trabaja con diseñadores industriales, inclusive este año al principio de año le hizo una propuesta para irse inmediatamente, pero entonces Carlos lo pensó mucho porque lógicamente él pensaba mucho en Mario, pensaba mucho en mi, entonces a la final le dijo que qué pena, que obviamente él tenía muchas ganas, pero que en el momento lo veía muy complicado. Además porque la idea era 
irse y no saber en qué momento podía regresar, era algo muy incierto. Pero sí ha habido propuestas así, pero obviamente ya en este momento no sé si todavía es posible por lo que ya está Mario, no sé...

T. ¿Lo ves más difícil?

L. Exactamente.

T. ¿O sea que su proyecto de viaje es un poco incierto?

PA. Sí, es muy remoto; aunque la verdad ella está insistiendo que me vaya, que realicé las cositas aquí, pero yo lo veo muy difícil porque yo nunca he salido fuera de Colombia e irse a encontrar con un país tan diferente... en la forma de vivir y sin una garantía... quedaría en manos de ella. Eso es lo que más me preocupa. Normalmente yo vivo de las cosas que yo hago, por fortuna tengo mi salud y vivo de las cosas que hago más una pequeña pensión que nos dejó mi esposa, pero ayuda. Entonces de eso vivimos, pero irse uno a la deriva allá a estas alturas de mi vida, dependiendo de ellos, cuando toda la vida he estado aqui...

T. Además usted está joven, ¿usted tiene cincuenta y qué? No sesenta y...

PA. No, yo pasé por ahi hace rato, yo tengo 67 años.

T. Ah, no nadie diría, entonces la calma le ha servido para poderse mantener...

PA. Eso me ha servido, yo soy muy calmado, me gusta analizar las cosas... no sé realmente porque me fue mal. A veces me pongo a pensar... ¿por qué me fue mal en el comercio? Hubo una época en la que me iba muy bien para qué. Lo que pasa es que en el comercio yo empecé también sin un centavo y me fue tan bien que tuve un buen apartamento donde ellas se educaron, en el norte, después tuve otro negocio, tuve camionetas de reparto, pero todas las cosas se desaparecieron porque yo empecé con un capital que me prestó el banco, pero afortunadamente le pagué al banco.

T. Es decir que usted ha sido una persona muy correcta...

PA. Sí, muy correcto y todo lo que realmente se fue de mis manos fue por cubrir obligaciones. Sí, entonces quedó únicamente la 
experiencia... y las hijas que las quiero mucho, yo quisiera verlas a ellas bien.

T. ¿Pero a su hija en España cómo la ve?

PA. Bien, nosotros hablamos y ella es muy tranquila, ella casi lleva la misma paciencia mía.

T. ¿Ella también terminó sus estudios?

PA. Si ella también terminó y el esposo estuvo aquí hace dos años, muy formal el tipo muy...

T. ¿Él es español?

L. Sí

PA. Muy buena gente, él es ingeniero mecatrónico, pero entonces lo que yo recalco ahi es que no se atenga al esposo, que mire otras formas de vivir por ella misma.

El relato del padre revela su historia de persona venida a menos que acepta con resignación los eventos dolorosos, sobre todo en el terreno laboral y económico. Se percibe cierto aire de impotencia para proteger mejor a sus hijas, en especial a Laura, quien es francamente motivo de sus preocupaciones. Destaca el papel de su otra hija como un referente de apoyo y de cierta satisfacción, aun cuando le advierte que no dependa de su esposo. Me conmueve su postura que ratifica un poco la imagen de fragilidad que se ha presentado de él en las sesiones anteriores y comprendo más que la sensación de desprotección de Laura no proviene de inseguridades propias, sino que en verdad, al menos desde el padre, parece que recibe una intención de apoyo fallida y una actitud de impotencia similar a la de ella. Identificada esta situación, procedo a conocer cómo el vínculo entre padre e hija es un recurso de autonomía o de estancamiento.

\section{La vida de Laura según su padre}

T. Y a Laura, ¿en realidad cómo la ve?

PA. ¿A Laura?

T. Sí, ¿cómo ve la vida de Laura?

PA. Bueno, la vida de Laura, me preocupa bastante, porque ya vimos que... empezando no tiene empleo, nació su bebé que 
todos hemos querido, ella nos comunicó a su debido tiempo y tratamos entre las dos familias de colaborarle lo que más pudimos; afortunadamente nació bien, nos alegra mucho la vida a todos ese bebecito y a ella la veo como truncada en su elección de educación, de poner a funcionar los pocos conocimientos que adquirió en la universidad. Digo eso aunque ella en sí casi no es comunicativa conmigo, hay falta de comunicación, yo trato de hacerlo pero ella a veces cree que únicamente ella tiene la razón, entonces yo la dejo.

T. ¿Y especialmente en qué temas es en los que no tienen tanto acuerdo? ¿Tú como lo ves?

L. Pues es que son varias cosas. Porque yo a veces siento que mi papá tiene una forma muy distinta de pensar a la mía, entonces de pronto, por las cosas que ha conocido y digamos... por la época en la que uno ha vivido, tal vez ya es muy diferente al pensamiento que mi papá tiene. Yo a veces siento que mi papá es muy conservador, entonces pienso que los conflictos vienen de la manera de pensar tan diferente. Yo sé que mi temperamento es complicado, pero sí, siento que la diferencia viene de abi y algo que me pasó durante el embarazo es que siento que tuve un cambio muy grande en mi forma de ser, pues me alteró muchas cosas. Yo siento que el embarazo me puso más histérica, más a la defensiva. Por eso a veces los comentarios de los demás, de pronto de Carlos o de mis tías, siento que son críticas todo el tiempo y siempre estoy como a la defensiva. Siento que asi estoy a partir del embarazo.

T. Púes no sé si en verdad como el embarazo fue un poco sorpresivo, quizás una parte tuya sintió que todo el mundo te iba a atacar y de una vez sacaste los escudos. ¿Pero todavía los necesitas?

L. Pues no sé, por momentos de pronto sí. Siento lógicamente que me equivoco y que de pronto trato de manera indebida a mi papá o a Carlos...

T. Digamos que ya a esta altura de la vida que ha pasado más de un año después del embarazo, en realidad ustedes son la 
familia... porque su otra hija está lejos... Hoy en día ustedes ya son dos adultos que tendrían que estar en colaboración, porque finalmente son los dos, de alguna manera cada uno aporta algo para la existencia del otro supongo... pues Jaime sigue siendo el papá, pero tú ya eres una mujer adulta. ¿En realidad qué te frena o qué te restringe de poder hablar directamente?

L. Pues sí, lo que pienso en un primer momento es que me juzgue...

T. ¿Y qué hace que tu papá te juzgue hoy en día?

L. Lo que pasa es que yo siempre... no sé... casi siempre me he sentido en comparación con mi hermana y ella como que pudo lograr más cosas. De pronto le fue mejor en su vida... entonces yo a veces siento que obvio, mi papá no me dice y de pronto no sea así, pero uno a veces siente que lo están comparando inconscientemente, entonces yo de pronto siento que cuando quedé embarazada y todo este cuento, como que de pronto mi papá iba a decir pues a ver su hermana ya está casada, mire que ella sí estudió, terminó sus estudios, Laura fue lo opuesto totalmente. Entonces a veces siento que me pueden juzgar por ese lado y también por mi falta de comunicación.

T. Lo que te entiendo es que ¿̇si estuvieras pensando desde el corazón de tu papá, tu lugar sería como de segunda categoría con respecto a tu hermana?

L. Pues a veces siento eso, uno se siente como...

PA. No, no, no. De ninguna manera, lo que pasa es que en la época en que se fue mi hija a España, yo tenía comodidades y las comodidades eran otra cosa. Por eso tocó reubicar los tiempos y el carácter de las dos siempre es diferente. Empezando que Laura fue una niña introvertida y la hermana fue muy sociable desde muy chiquita, desde muy pequeñita consiguió muchos amigos, en cambio Laura no. Ella es de la casa, como muy introvertida, no le gustaba la rumba, la otra era muy rumbera (ríe). Pero yo nunca he pensado que a una la quiero más que a la otra; yo las quiero mucho a las dos, muchísimo. Y yo digo, si Dios 
me da una nueva oportunidad económica, el compartimiento va a ser para las dos, así la una esté mejor que la otra, mi amor es tan grande y tan bien compartido, que yo no puedo creer que alguien piense que quiero más a la una que a la otra.

T. ¿Y de Laura en realidad qué admira? O ¿qué le gusta de ella? PA. Ella es una niña muy trabajadora, muy echada para adelante; lo que pasa es que le tocó la época de las vacas flacas. Ella creo que tenía tantas cosas en la mente que realmente se le truncaron un poquito con el embarazo, pero bueno, vino Mario que es la alegría de todos y eso recupera lo que se perdió. Yo le digo que retome su vida, salga adelante, es que ella es muy apegada a Mario.

T. Ya entiendo. ¿El niño ya entró al jardin?

L. Sí lo están cuidando.

PA. Sí lo están cuidando, pero a mi me preocupa que desde que entró Mario a que lo cuidara esa señora le rinde menos el trabajo que cuando lo tenía ahí. Normalmente, aquí hablando con franqueza, yo soy el que cocina el alimento de la casa, comemos los dos. Ella es la encargada de lavar nuestra ropita, pero en estas tres semanas se le ha acumulado una cantidad de ropa. Yo no le he dicho nada, hoy se lo estoy diciendo acá delante de la doctora y he visto que se ha vuelto como más dejada con el aseo de lo que nosotros necesitamos. No sé qué le estará pasando; no se lo pregunto porque a veces ella poco se mete conmigo, cree que yo no soy un buen consejero o que soy muy anticuado con los consejos que le doy o que no le sirven de nada. No me gusta porque muchas veces hago los alimentos y comemos como si estuviera uno por allá y otro por allá, no me gusta nada.

T. Qué triste...

PA. Y eso no me gusta, pues yo vivo a veces mal por eso. Entonces no sé qué le estará pasando a ella. Quiero que se lo cuente aquí a la doctora frente a mí.

T. ¿Qué dices?

PA. Yo sé que a ella le ha hecho mucha falta la mamá. 
Cuando Laura explica su comportamiento actual una vez más en el embarazo, sin desconocer el impacto de este hecho, empiezo a confrontarla en función del tiempo transcurrido y de la realidad ya más conocida acerca de sus fuentes efectivas de convivencia y de apoyo. Me empieza a cuestionar la posible creencia subyacente en ella de que la maternidad todo lo justifica y me alerto sobre una idea que había tenido en sesiones anteriores acerca de que estuviera escudándose en la crianza del bebé y en su condición de madre soltera para no asumir su vida. Por esto, sin desconocer la relativa validez de la actitud de resignación y cierto desvalimiento del padre ante las pérdidas que ha tenido, pongo de presente la realidad de la composición familiar para entrar en forma más concreta a los frenos que ellos se ponen para asumir más proactivamente su situación presente.

Se pone claramente en evidencia el mantenimiento de la pauta de recelo y defensividad de Laura, basada en sus experiencias tempranas de invalidación y descalificación, que la desgastan en una fantasiosa autoprotección que esgrime ante las expectativas de su entorno, percibidas como ataques.

La presencia del padre es la oportunidad para confrontar directamente esos temores; la declaración del amor equitativo hacia sus hijas y la caracterización positiva de cada una de ellas con sus diferencias, constituye una potentísima forma de que así, sin darse cuenta, él revise la posible imagen desvalorizada que quizá sí tiene de Laura, con lo cual simultáneamente la invita a ella a diluir sus temores y sus fantasías catastróficas sobre lo que los demás piensan de ella. Considero que este tipo de confrontaciones es una importante justificación para la presencia de los miembros del sistema familiar en la terapia, pues la fuerza de las palabras encarnadas sin duda supera el efecto de las que serían apenas representaciones de diálogos imaginarios y proyectivos, cuando no se cuenta con la asistencia de ellos.

Las palabras del padre permiten además que Laura distinga entre el afecto y la valoración incondicional como persona, de las razonables expectativas sobre el desempeño de sus roles, cuya eficacia es directamente cuestionada con el padre, quien confiesa su malestar porque 
a pesar de los recursos que le han facilitado para que se sienta más aliviada de tareas domésticas y de la crianza, no la ven evolucionar.

No obstante esa evidencia, no me detengo en el tema de las obligaciones del rol, sino que decido continuar por la vía de las emociones, pues considero que este terreno es más propicio para movilizar el cambio que el de los contratos sociales que pueden desencadenar de nuevo discusiones sobre lo que en justicia corresponde asumir como responsabilidad.

En esa línea, el padre reafirma los efectos de la ausencia de la madre y tengo la sensación de que esta será la ocasión para ayudarles a los dos a abordar ese asunto pendiente. No obstante, como se verá enseguida, ese no era el mayor dolor de Laura a estas alturas.

\section{La sorpresa oculta que activa a Laura}

L. (Llora). Pues últimamente las cosas no han estado bien, sobre todo con Carlos. No sé, mi relación con él cambió mucho, yo cambié mucho con él. Nosotros llevábamos una relación ya de seis años; en ese trayecto han pasado muchas cosas y Carlos se ha metido con otras mujeres, muchas veces y no lo quería comentar porque me sentía juzgada; siento que me van a decir: "tú estás enamorada de un tipo que literalmente no vale la pena" y Carlos es una persona que, es muy raro decirlo, pero asi como tiene muchas cosas buenas, tiene cosas malas. Yo nunca pude decirle a Carlos que no sigamos la relación, en su momento lo bice y terminábamos, pero, pues lo mismo, yo no soy de muchos amigos, de muchas...

T. Claro, más bien aislada.

L. Exacto me apegué mucho a él, a su familia y me cuesta trabajo alejarme. Entonces digamos que nunca hemos terminado, nunca ha habido en si un tiempo lejos; cuando yo quería realmente hacerlo quedé embarazada; quiero como alejarme, pero nunca he podido tomar la decisión y cuando quedé embarazada pues menos. Igual yo sé que él también me quiere, pero no entiendo si él me quiere distinto o tiene una idea de amor diferente a la 
que yo tengo; yo soy muy correcta en esas cosas, puedo tener encima lo que sea, pero me mantengo en mi lugar; sin embargo las cosas entre él y yo cambiaron mucho.

T. Entonces recientemente ¿qué es lo que él ha planteado?

L. Pues lo que pasa es que, teníamos esa idea cuando yo vine con él de estar juntos, pero en estos días me di cuenta de algo que volvió. Me di cuenta que hay una mujer en el trabajo que está ahi detrás de él; él tuvo su rollo con ella, lo encaré, él se puso muy mal, me dijo que no sabía qué le pasaba, que sentía que yo lo ignoraba todo el tiempo que si lo necesitaba era solo para cosas del bebé. Obviamente me sentímal, siento que tiene razón en cierta medida, pero le dije que por qué no me decía; puede que con otras personas no sea comunicativa pero con Carlos si lo soy. Pero él conmigo se guarda cosas, entonces me dijo que a veces se sentía en una monotonía.

T. Claro, pero entonces en este punto ¿en qué estas con él?

L. Yo hablé con él este fin de semana, le dije que evidentemente no me puedo alejar del todo porque está el niño. No sé cómo manejar la situación, porque él me dice que le importo pero no me quiere seguir haciendo daño, entonces yo le digo ¿cómo hacemos?

T. ¿En calidad de qué?

L. Exacto, yo le dije que en este momento no me siento capaz de seguir en todo esto.

T. Además es una relación que no se sabe para dónde va, porque ¿qué eran? ¿Novios, esposos, amigovios?

L. Sí, yo le dije a mi papá que nunca lo catalogara como mi esposo, porque para mí eso es alguien con quien vivo, o alguien con quien estoy organizada de manera muy formal.

T. Que todo mundo lo sepa, algo público.

L. Exacto, pero yo no me sentía así, sino que igual seguía siendo mi novio. Pero ahorita hablé con la familia de él; supieron todo y les dije que no me sentía capaz de continuar con él y que más bien dejáramos las cosas así; dejé claro que seguiría siendo el 
padre de Mario y esa situación no cambiaría. Igual todavía no se ha aclarado bien todo, pero abora lo que siento es eso, siento que ya no puedo seguir en la misma situación.

T. Seguir ahí como en el limbo.

L. Exacto, yo sé que él ha hecho muchas buenas cosas por mí, que son evidentes y se las agradezco mucho, otra persona no lo hubiera hecho.

T. Bueno, era su responsabilidad.

L. Pues sí, en parte.

T. Es respetuoso, pero eso no es nada tan extraordinario realmente.

L. La situación es esa; estaba esperando contarle a mi papá en el fin de semana, quería hablar con él, porque lo que tampoco quiero es que le coja rabia a Carlos.

T. Eso si tu papá es libre de sentir lo que quiera; el punto es cómo lo maneja.

PA. Es complicado siempre. Yo sí le dije en una ocasión: el día que usted no sienta nada por Laura, no la haga sufrir, dígale de frente las cosas.

T. Claro, lo que pasa es que los corazones humanos no son tan así, separados e independientes como los cajones del escritorio; sino que uno puede sentir un poquito por esta persona y a la vez por la otra y por la otra; por eso se mantienen relaciones que son ambiguas. Pero me parece que habla muy bien de ti, que tomes una postura más clara, porque si no, así podrías continuar toda la vida, viendo a ver si por fin es tu turno.

PA. Yo creo doctora que es lo más conveniente.

T. ¿Qué?

PA. Que él tenga una relación por allá, diferente.

T. Ah, es parte de su decisión.

L. Lo que entiendo yo, es que él no tiene una relación con ella.

T. Pero tampoco se define.

L. Exacto, pues con ella en este momento no están hablando. Realmente no lo sé. Pero tampoco conmigo; yo le decía: ¿entonces para qué decías que te ibas a vivir conmigo? ¿A qué estabas 
jugando? Y me dice que es muy raro. Su posición es que él me quiere, que quiere estar conmigo pero no sabe qué le pasa y no sabe porque se fija en otras.

T. Bueno, pues por las razones que sea, él no está siendo una persona confiable para estar centrado en una relación contigo; por lo menos es honesto en decirte que no está seguro; entonces tú tienes elementos para decidir; él juega a esta indecisión, a esta ambigüedad. Creo además que te hacía falta esto para saber si tú vas sola, vas con él, vas con tu papá, vas con quién. De pronto tenías otras ilusiones, pero por lo menos esto es más claro.

L. Sí, por lo menos me siento bien en ese aspecto.

T. ¿Eso era lo que querías hablar por aparte?

L. Sí.

T. ¿Y ahora cómo te sientes hablándolo aquí, aprovechando esta situación para contárselo también a tu papá?

L. Obviamente, pues más tranquila de que sepa; igual para mí no es fácil decírselo a él, pues nunca ha habido esa comunicación y me cuesta contarle cosas muy personales.

El relato de Laura presenta un desenlace inesperado pero no tan extraño en este tipo de casos, coherente con la progresiva clarificación de su lugar en la vida y en las relaciones. Muestra sobre todo una entereza que no había aparecido en las sesiones anteriores y que resulta clave para el destrabe de su evolución personal. Para bien o para mal, salen a la luz las dudas profundas de Carlos para formalizar la unión, asociadas quizá a una decisión de no asumir las que podrían ser para él prematuras responsabilidades dentro de su proyecto personal en esta etapa de su trayectoria de vida. Con esta premisa de base, no me detengo en el tema de la infidelidad, pues desde mi punto de vista, esa sería tan solo una buena excusa para no abordar de frente los motivos emocionales para no legalizar la unión. También intento ser muy cuidadosa para no juzgarlo a él como persona ni acudir a consideraciones morales sobre su comportamiento, sino que me enfoco más en el efecto interaccional de las dudas, definiendo como ambigüedad la indefinición sostenida desde el embarazo hasta el momento. 
Se ratifica la activación de su entereza al mantener la decisión de ruptura aun admitiendo que había permanecido en la unión para no perder a la familia política como núcleo de pertenencia y por lo tanto considero que hay que hacer lo necesario para validar su postura de afirmación en este momento.

\section{Cuestionamiento de la postura homeostatizante del padre}

T. ¿Cuáles son los juicios que temiste nuevamente? ¿Cuál sería el juicio que podría hacer tu papá?

L. Es como un temor tonto por así decirlo, pero de pronto por las expectativas que ellos tienen de mí, o que mi papá tiene de mí..

T. Pero ¿̇ú le has preguntado?

L. No.

T. ¿Qué espera Jaime de ti? Aprovecha...

$L$ ¿Qué esperas de mí?

PA. Uno como papá, vuelvo y lo repito, uno quiere que sus hijos estén bien.

T. Dígale de manera directa a Laura que es lo que quisiera que pase ahora en la vida de ella, ahora que están acá todas las cartas sobre la mesa...

PA. Lo que quiero es que si sigue con Carlos, es que concreten la relación.

T. Bien, pero ya nos está diciendo que eso no va para ella; así como están las cosas parece que no le convienen...

PA. ¿Pero has averiguado bien?

L Sí, porque vi muchas cosas ya...

T. Tienes evidencias...

L. Tengo evidencias y él lo aceptó.

T. Lo aceptó, además.

PA. Ya, ya, ¿pero que corten la relación así? digo yo...

T. Bueno, parece que la pregunta no es exactamente esa. La decisión ya la tomó... En la vida, ¿qué espera de la vida hoy? Que lave la ropa, que se quede en la casa, que aporte plata, que se vaya de la casa, que consiga otro marido ¿qué quisiera? (risas). 
PA. No, no, yo lo que quisiera es que continúe criando esa bendición que Dios nos mandó y nos alegra el hogar, que siga estudiando y que se prepare porque en este momento las cosas son de preparación.

T. Pero tú ya tienes un título.

L. Sí.

T. Y mientras tanto...

PA. Yo la apoyaré en lo que sea.

T. Ya... ¿Y tú cuántos años es que tienes? ¿27?

L. 27.

T. ¿Y tú te sientes bien a los 27 años con un hijito, con una experiencia de vida, en un papel... perdón que yo sea así... en un papel de niña de papito, que papito la mantiene con grandes dificultades?

L. No, claro que no.

T. Muy generoso de su parte, pero eso no es bueno para ella.

PA. Sí eso no es bueno, a mi me lo han dicho varias personas...

T. ¿Y cómo le cae que yo se lo diga?

PA. No, no, muy bien. Cuando estaba trabajando me decian: don Jaime, es bueno que usted no le aporte tanto a su hija porque le está haciendo un mal. Pero el problema es que como yo soy de un corazón tan grande y bondadoso...

T. Pero el corazón puede ser engañoso. Porque entonces yo me atrevo a decirle algo y me perdonará, pero yo sé que nosotros dos quien sabe cuándo nos volvemos a ver en la vida: si usted quiere que su hija esté al lado suyo, usted no necesita tenerla a ella chiquita, necesita dejarla que crezca.

PA. Sí, sí, muy cierto.

T. Y para que ella crezca, usted necesita que salga como una mujer capaz de ser autónoma, productiva, capaz de defenderse en la vida con su ayuda o sin su ayuda. Porque es distinto si abora ustedes establecen una relación de dos adultos en colaboración, a si usted necesita que ella sea la incapaz y le parece que ella todavía no está lista para afrontar la vida, cosa que por lo que 
yo conozco en Laura, no es lo que hemos visto. Ella es una niña muy trasparente en lo que he podido conocer, tiene todas las condiciones para afrontar la vida. ¿Cómo es que se llama su esposa? Se me olvidó... Si Martha estuviera escuchando esta conversación, si estuviera ahi sentada ¿qué le diría?

PA. Martha era una mujer muy independiente y muy echada para adelante. Yo creo que ella en este momento ya la tendría quién sabe haciendo qué, porque ella era muy rebuscadora.

L. Y estaría muy molesta...

PA. Y estaría molestándole la vida a ella...

T. ¿Solo a ella?

PA. De pronto a mí también.

T. ¿Diciéndole qué?

PA. Que no le acolite las cosas.

T. Ah, que se pusiera las pilas, que se moviera (aplande).

PA. Sí, sí, lo que pasa es que llega uno al momento en que se acostumbra a las cosas, he sido sin vergüenza...

T. Ah, menos mal usted se está confesando acá.

PA. (Risas).

T. En eso no se pueden inconscientemente arrastrar el uno al otro, porque así como están, los dos se pueden quedar toda la vida, que es llevar una vida gris, de mantenimiento y que si hoy comemos arroz con huevo frito pues bien, pero si no hay carne, pues bueno, no importa. ;Pero no merecen eso!

$P A$. Es difícil únicamente vegetar. Eso es lo que me preocupa mucho a mí.

T. ¿En qué sentido le preocupa?

PA. Me preocupa porque realmente no tengo una vivienda donde meter las cabezas.

T. Bueno, pero es que fíjese que me llama mucho la atención la manera tan generosa, si es muy generoso, pero es como si, sin darse cuenta, habla como si ustedes fueran una pareja: ¿dónde metemos nuestras cabezas?

PA. Sí, como si sintiera la obligación de llevarla a ella... 
T. Sí, o es la niña chiquita o es la esposa, pero en realidad no es ninguna de las dos cosas.

(Rien).

T. Y entonces es distinto si usted dice: me preocupa que yo a mis 67 años no tenga donde meter la cabeza. En cambio Laura tiene 27, tiene un título, ¿usted tiene un título?

PA. No.

T. Bueno, tiene un título, tiene muchos encantos y tiene un papá del niño que no es el más fiel del mundo pero le está respondiendo por la criatura. Sería distinto su discurso...

L. Sí, yo a veces siento y a veces se lo digo a mi papá, porque cuando mi hermana le propuso irse a España, él se hizo a la idea de quedarse por mí. Yo le dicho eso a mi hermana, que no estoy de acuerdo, porque mi papá tiene todo el derecho a irse.

T. Además tú no eres la primera madre soltera del mundo, hay mujeres que mantienen una cantidad de niños. Tú eres linda, eres inteligente, tienes un titulo, tienes capacidad de trabajo ¿cómo no vas a poder sacar un hijo adelante?

L. Entonces yo a veces le dijo eso a mi papá y él ve otros factores...

T. Bueno, ya esa es su vida, pero no todos en el mismo paquete...

L. A mí me gustaría que él se fuera. Empezando que mi papá habla a futuro, que cuando tenga otra vez el negocio... Con toda sinceridad eso nunca va a pasar, es difícil, ya es momento de que piense en otras cosas en su vida...

T. Hay pequeñas pero duras realidades y es que sin una pensión propia a los 67 años, nadie le presta a uno nada...

L. Entonces la propuesta que hace mi hermana me parece buena porque cambiaría el panorama.

T. Bueno, esa sería la decisión de él. Lo que yo estoy viendo aquí es que son dos existencias que se quieren entrelazar y están de hecho entrelazadas, pero se están entrelazando para quedarse quietas y eso si es un peligro.

PA. ¿Qué sugiere que hagamos doctora? 
T. Todavía no lo sé. Voy a hablar con los colegas del otro lado. Entonces también les dejo esa pregunta: ¿qué piensan? ¿Si están de acuerdo con estas ideas?

Me llama mucho la atención que el padre adopte una postura de cuestionamiento a las percepciones, motivaciones y argumentos de Laura, con todo y que se trataría, culturalmente hablando, de la traición de Carlos hacia su hija. Esto me hace pensar en que no es por azar que además de la descalificación en la comunicación con los padres, Laura haya sufrido muchos dobles mensajes que explicarían aún más su inseguridad hasta en las percepciones más elementales acerca de sí misma.

Esa actitud del padre me despierta una sensación de sorpresa y de cierto desagrado, porque me hace pensar en que él no se pone en los zapatos de ella como persona y quizá teme que quede más desamparada, con lo cual reaparece lo que Laura siente en el fondo, que es la desconfianza del padre en sus propios recursos y autopercepción de protector fallido. Esto se confirma cuando con mucho trabajo, el padre explicita unas expectativas de seguir cuidando a Laura como niña inhabilitada para afrontar su vida. Esta vivencia me impulsa por lo tanto a confrontarlos sobre sus condiciones reales, pues me temo que de no hacerlo en este momento, se perdería todo el efecto de autonomización en apariencia movilizado en el proceso.

Siento que tengo que ser muy cuidadosa al calibrar la fuerza de la confrontación, porque a pesar de la intensidad emocional de la sesión, no debo olvidar que acabo de conocer al padre y no hay un vínculo creado con él, pero también soy consciente de la incertidumbre de volverlo a ver. Como una alternativa intuitiva, busco traer la voz de la madre, quien imagino que tendría de la situación presente una versión compatible con la mía, de modo que así no será la psicóloga quien expone una orientación para el cambio, sino la persona a quien los dos le conceden la autoridad y la fuerza. Por fortuna esa voz en realidad potencia el efecto de la confrontación y el padre alcanza a reconocer su postura "sin vergüenza" de pasividad y comodidad.

También me impresiona cómo uno se puede engañar llamando generosidad lo que puede ser dependencia conveniente y me alegra 
que Laura sea también capaz de cuestionar al padre sobre sus planes fantasiosos y sobre el hecho de que ella se convierta en la excusa para que él tampoco siga su vida. Su pedido de que yo les diga qué hacer, lo percibo como una muestra adicional de su pauta y en cierta forma siento que nuestra tarea es ayudar a Laura a salir de allí, pues parece difícil que su padre quiera cambiarla. Por esa razón no me niego a respondérsela sino que aprovecho la pausa para posponer mi reacción.

\section{Intersesión}

T. ¿Cómo la vamos viendo? ¿Qué ven del caso, por dónde continuamos, qué hacemos?

Y. Ese momento que acabó de pasar me pareció bien interesante: confrontar al sistema desde eso que no habian visto antes.

J. Yo estoy viendo que el sistema se está moviendo, no solamente la familia sino también el del chico y los sistemas empiezan a recomponerse. En particular a la chica la he visto movida hacia una autenticidad hoy y y mucho más posicionada como mujer respecto a la independencia de los hombres. Me preocupa la postura del viejo, porque también es ambigua respecto al modo de amar, de definir las situaciones. Creo que para esa especie de simbiosis entre ellos, por hacer la metáfora, toca crear una estrategia que pueda liberarlos a ambos, que entiendan cómo es un sistema de protección humana. Yo creo que si el padre quisiera liberar a su hija, comenzaría la historia más con apoyo concreto, con decisiones concretas y ella asumiría más su posición. Creo que él le manda mensajes muy ambiguos a ella, que la atrapan, ella quiere desentramparse, pero él le manda mensajes de atrapamiento. Creo que es importante confrontar mucho más al padre respecto a su postura frente a ella. Que él pueda también entrar a una reflexión acerca de lo que está haciendo, que él cree positivo, pero que a la larga...

T. Lo protege a él. 
J. Lo protege a él de sus miedos, por eso él dice: me voy para España, pero el atrapamiento de su historia es tan grande que dice: "si me voy a España, ya no puedo amañarme y si me quedo aqui, entonces cuido a mi hija". Pero no ha podido asumir su soledad, después de la muerte de la esposa. La chica está encarando, me parece que confrontar sobre sus recursos es un punto vital para la trasformación de ella en este momento, es lo que yo he visto en el proceso.

T. Los dos se atrapan y el tema no es el viaje.

J. No es el viaje y queda atrapada también en la relación con el otro chico, está atrapada en relaciones ambiguas con los hombres.

Y. Y con todo el mundo a su alrededor.

T. Porque van a poderla evaluar.

Y. La hermana, las tías, a cualquier persona ella le confiere el poder para que evalué su vida...

J. Me estoy preguntando, estratégicamente, hacia dónde es pertinente dirigir el proceso, sobre qué foco de lo presente...

T. Ya que el señor creo que se sintió francamente aludido y que ya ahoritica está timbrado, a mí me gustaría invitarlos de nuevo a los dos, puede ser para conversar en conjunto o por separado. La idea de traerlos a los dos es ayudarles a ponerse de acuerdo en una colaboración en la vida, porque por abora las circunstancias los obligan a estar ahí.

J. Cómo protegerse sanamente para seguir su evolución cada uno.

T. Sí, en una relación padre-hija como dos adultos. Lo demás, verá cada uno para qué necesita ayuda, bajo la idea de que viven una relación simbiótica, cada uno pretendiendo que puede hacerse cargo del otro, de los sentimientos y la felicidad del otro: la peor mentira de la vida.

J. Están cuestionadas sus dos autonomías.

T. Los citaría para dentro de dos semanas.

Coincidimos en la lectura de los colegas del equipo y comparto sus interrogantes sobre cómo continuar avanzando en la superación de la pauta simbiótica. 


\section{Cierre}

T. Bien, ¿̇entonces qué pensaron? ¿Qué aclararon, qué vieron, qué ampliaron?

L. Mi papá preguntándome qué quiero hacer aborita con la relación, obviamente se molestó mucho.

T. ¿Sí?

PA. Pues bastante. Porque realmente lo que le comentaba a la doctora, yo le dije eso: cuando su relación la sienta mal, enseguida comuníquele y no la haga sufrir.

T. ¿Y qué le molesta?

PA. A mí sí me molesta esto que está sucediendo.

T. ¿Qué? ¿Qué le molesta en concreto?

PA. En concreto, me molesta que él no es comunicativo, no sé si le corresponda a él decirme alguna cosa, pero él tenía mi confian$z a \ldots$

T. O sea, ¿usted se siente engañado también?

PA. Sí.

T. ¿Usted le preguntó: usted qué es de mi hija?

PA. No.

T. ¿No le preguntó?

PA. No.

T. Porque si es así, él no sabría tampoco que esperar.

PA. Pero sí me siento engañado porque realmente en esa conversación que tuvimos le dije eso.

T. Perdóneme le hago otra pregunta: ¿qué le hace esperar a usted que él le concediera la autoridad como para contarle los deseos que él tiene?

PA. Bueno, no, porque realmente respeto la intimidad de ella.

T. Correcto, ¿pero era realmente su yerno?

PA. Pues no sé doctora.

$L$ Porque ella dice que no son esposos jentonces?

PA. Si, la relación de ellos ha sido muy...

T. Ambigua. Y la suya con él también. Entonces ¿en calidad de qué usted podría esperar que Carlos le contara algo? Eso es 
parte de los engaños en los que uno entra cuando es ambiguo en la definición de las relaciones y es una de las cosas que estábamos conversando con los colegas. Que hay un foco presente alrededor tuyo, que es la ambigüedad en las relaciones, porque los dos legalmente son padre e hija, pero actúan de una manera que no se sabe qué son. Porque ya no es lo que correspondería claramente para la relación de un padre con una hija adulta. Tú con Carlos tienes una relación ambigua y con tu hermana y tus tías relaciones ambiguas. Porque por razones que vamos comprendiendo, sin darte cuenta, le has dado poder a todo mundo para que sean no solo tu pariente sino tu juez y eso es una ambigüedad en la que tú quedas muy mal colocada y así cualquiera se siente inseguro para afrontar la vida. Cuando uno se mueve en relaciones ambiguas está dispuesto a cualquier cosa y normalmente sale mal. Entonces ese disgusto con Carlos ¿Como para qué? ¿Qué males le hizo a usted? ¿Acaso él acatará sus reclamos?

PA. Sí, queda entonces salir adelante porque qué más...

T. ¡Aleluya!

PA. Una pregunta mía es ¿cómo debo portarme yo en este momento?

T. Pues la verdad yo no tengo una forma directa de responderle esa pregunta porque a mí no me corresponde.

PA. Sí, sí.

T. Lo que nosotros quisiéramos con mis colegas, para analizar todas las circunstancias necesarias para responder esa pregunta, sería que vinieran los dos en una siguiente oportunidad, porque creo que es muy positivo, primero que usted haya querido venir y que esté en esta apertura que no sé si tu conocías de tu papá y que quizás no habias aprovechado lo suficiente.

PA. A mí me preocupa que como lo mío es el comercio y la distribución, yo le vengo diciendo a ella hace rato que como no ha podido encontrar empleo en su carrera que porque no trabaja conmigo. 
T. Yo pensaría que todas esas son sugerencias útiles, pero no podemos responder, es una opción interesante pero habrá que ver si eso es lo que quieres en la vida, si ese es el trabajo que quieres tener. ¿Sabe cuál es el problema adicional y más importante? Que seguirían casaditos los dos...

PA. (Risas).

T. Usted, primero está en los 67, segundo, tiene su gracia, ¿̇entonces? ¿Qué hace? Búsquese a alguien también, una compañia que le sirva a usted en la vida.

PA. Lo he intentado, pero ha sido muy difícil. Trabajé con una señora que nos caíamos bien, pero ella era cristiana, la barrera era que para estar con ella, tenía que ser cristiano y bautizarme y a estas alturas de la vida, nooo.

T. Pero no es la última coca cola del desierto. Pues tenga amigas, haga una vida...

PA. Sí, yo las tengo sino que eso demanda platica, atención.

T. También hay amigos generosos. Para uno pasarla bien no necesita dinero, es más la disposición...

PA. (Risas) Sí, a mi me gusta, pero bueno vamos a ver qué pasa.

T. Por eso más que responderle directamente a su pregunta, nos gustarían dos cosas: una es que ya con la claridad de la situación de Laura, cada uno en verdad piense en este momento qué quiere, se den cuenta de qué es capaz cada uno para reorganizar su vida en colaboración con el otro y para eso necesitan claridades. La otra, que vengan el viernes después de semana santa y ojalá este entrenamiento breve en conversar que tuvieron aquí, lo repitan en la casa así sea para hablar del clima.

PA. Muchísimas gracias.

T. Nos agrada mucho trabajar con ustedes, porque se nota la capacidad que tienen para salir adelante.

PA. Gracias.

L. Gracias.

T. Con mucho gusto. 
Hubo necesidad de continuar con la confrontación al padre pues ciertamente le cuesta imaginarse rehaciendo su vida y ello se convierte en un enganche que puede restringir la autonomía de Laura.

\section{Quinta sesión}

Quince días después. Asiste Laura sola.

\section{Seguimiento del estado de cosas}

L. Mi papá sí quería venir y era la intención, pero no pudo a última hora.

T. Bueno, ¿y cómo les fue en semana santa?

L. Bien, estuvimos con mi papá, con Mario, fue Carlos a visitar a Mario, vino la hermana de él. Ella cuando viene quiere estar con él, por el cuento de que es la madrina.

T. ¿YY tú? Estás muy bonita.

L. Sí, me corté el pelo, cambie de look, quería hacerlo desde hace rato.

T. Y quedaste como de veinte...

L. Me dicen que parezco una niña. Sí, señora.

T. ¿Y qué pasó después de esa conversación con tu papá?

L. Pues con mi papá hemos estado mejor; trato de hablar más con él, de compartir más con él. Me pregunta más sobre lo que ha pasado con Carlos, porque a mi me faltaba contarle más de mí. Me pregunta qué quiero hacer, cómo van las cosas con él... ahí vamos.

T. ¿Y con Carlos cómo vas?

L. Con Carlos también he hablado mucho; hemos tenido muchas charlas, sino que en el momento, como es tan reciente todo, hay veces en que yo trato de estar bien con él, de verlo como el papá de Mario pero hay días en que sí es difícil. Porque él me dice: lo que pasa es que yo siento que tú me estás tratando muy duro. Yo le digo que ni modos, es lo que pasa y no me puedo hacer la loca. Lo último en lo que quedamos es en llevar la relación como amigos. Con Mario la idea es que lo siga viendo regularmente. Ahorita Mario ya entra al jardín y él dice que lo va a visitar día 
de por medio. Y los fines de semana estamos viendo qué hacer, porque a veces llegamos a la idea de un fin de semana tú, un fin de semana yo. Pero es difícil porque nos gusta compartir tiempos juntos y no la pasamos mal; como que queremos salir los tres, porque asi estábamos acostumbrados y es raro llevarse a Mario por aparte.

T. Claro, pues por abora fluye así. El tema es que en la medida en que sobre todo tú tengas una vida más propia, independiente, laboral y todo eso, seguramente tendrás otros mundos, otras actividades y te irás parando más claramente, ¿no?

L. Si, exacto, porque yo le decía eso a él. Mi mundo fue él.

T. Y llevas ya un tiempo largo en ese pequeño cosmos...

L. Yo le decía que para mi también es difícil ver otras cosas, pero toca, porque igual no puedo seguir abí..

T. No.

L. Como quien dice, detrás de él...

T. Y el capitulo de maternidad, bebé, ya. Es el momento de retomar tus cosas y está todo para que lo puedas hacer.

L. Sí, la idea del jardín era esa, que yo pueda ver por mí. Abora sí tocó, no es por si acaso, sino que realmente toca o toca.

T. Y en ese aspecto de la búsqueda de las oportunidades ¿en qué punto te sientes?

L. Enviando hojas de vida y con Mario lo he llevado a terapias que le programan.

T. ¿Son terapias de qué?

L. Fisioterapia y terapias de lenguaje. Entonces he estado en esa rutina. He hablado también con mi papá, le he dicho para repartirnos mejor el trabajo de la casa, ponernos un día específico para hacer tales cosas.

T. Es de organización...

L. Sí, señora.

Los rituales y las relaciones con el padre, el niño y con Carlos se van ajustando conforme a las decisiones tomadas, lo cual habla de la consistencia y la conveniencia de las mismas. Hasta en la apariencia 
física se notan los cambios de Laura hacia la afirmación personal. Queda pendiente, como corresponde al momento, establecer la dinámica de la relación con Carlos como padres del niño, asunto que me parece crucial para que no caigan en otras confusiones. Da la sensación de que la propuesta de hacer cinco sesiones va dando resultados positivos y por lo tanto me dispongo a ser muy precisa en lo que se aborde en esta sesión, previendo el cierre del proceso.

\section{Evaluación de los efectos de la terapia y ajustes propios de la ruptura de pareja}

T. Y en comparación a cómo llegaste acá ¿cómo sientes que se ha avanzado?

L. A comparación de cómo llegué, me siento con los pies más en la tierra. Además que lo que pasó con Carlos me tocó. Me siento más activa, más consciente, más realista de las cosas. Lo que me pongo a pensar, o lo que quiero es definir esa situación con Carlos más que todo. Yo le decía a él: un tiempo como para qué... si tú me quisieras o me amaras no bubiera pasado lo que pasó y en este momento el comportamiento sería distinto. Él me dice que siente que le tengo rencor, rabia, que quiere que yo sane eso para llevarnos de mejor forma. En parte lo entiendo, pero no sé qué hacer.

T. Claro, porque entonces es como si él sintiera que no tiene consecuencias...

L. Exacto. Yo le dije: "tú tienes que ser consciente que de lo que hiciste tiene consecuencias y no es que porque pasó un tiempo yo pretenda verte mejor". Obviamente por Mario trato de llevar las cosas de una forma tranquila. Mi papá se molestó mucho y Carlos sintió eso y dijo que si mi papá quería que no volviera, él no volvía. Hablé con mi papá y entendió que igual es el papá del niño y en eso estamos. Ahorita de pronto la familia de él, como que tienen ese pensamiento...

T. Al patadón se le echa pomadita...

L. Exacto, lo siento así. Más que todo de la mamá de él; yo un día si le dije que no veía las cosas de ese modo; Carlos debe asumir las consecuencias de lo que hizo. Le dije que no me quería volver 
a quedar allá, porque debía aprender a desapegarme; pero ella es una persona como muy bondadosa y me decía: "no, mamita tranquila"; pero no entiende la magnitud de las cosas. Le dije a Carlos que tratara de hablar con ellos para que también lo entiendan, porque quieren que comparta como si nada.

T. ¿Y entonces cómo vislumbras tu vida ahora y cómo te sientes tú contigo?

L. Pues por un lado quiero lograr esa independencia que no tuve en mucho tiempo, hacer más las cosas por mí, dejar de pensar tanto en él. Es difícil, él cree que todavía estoy ahí para él, que espero.... Pero no quiero que a él se le sigan facilitando las cosas así no más. Yo quiero darme cuenta y asumir que puedo estar sin él, que un fin de semana puedo estar sin él, distraerme en otras cosas, no encasillarme en que si no estoy con él se me acaba el mundo. Eso es lo que quiero tratar de hacer, pues obviamente me siento culpable de lo que pasó.

T. ¿Culpable de qué?

L. De lo que pasó con él.

T. ¿En qué sentido?

L. De que él hubiera buscado a otra persona, pues en algún momento me dijo que no sabía cómo hablarme, cómo tratarme y eso me hizo sentir culpable.

T. ¿En qué sentido culpable? Porque yo puedo entender que eso lo haya hecho sentirse frustrado o no sé cómo, pero ¿tú eres responsable de que él haya actuado de ese modo con otra mujer?

L. No, exacto, pues tampoco a ese punto.

T. Porque dijiste bueno, o esto se arregla, o se acaba, porque esto no me lo resisto.

L. O sea, a veces me pongo en esas dos posiciones; me siento culpable pero digo, no, tampoco; de pronto me encasillé en el bebé, mi genio subió, pero no era motivo, como yo le decía a él, si algo le molestaba que me lo hiciera saber y así le di la oportunidad y abí es cuando digo: no debo sentirme culpable.

T. Claro que no. 
L. Porque él tendría que haberse acercado a mí para decirme esto y esto, pero no lo bizo.

T. Claro.

L. Quiero es tratar de sacarlo a él un poquito de mi mundo.

Laura identifica con claridad los efectos del proceso y el impacto del comportamiento de Carlos que la empuja a dejarlo. No obstante, pareciera que a él le cuesta salir de la ambigüedad e intenta mantenerla ahora ofreciendo que se den un tiempo para definir la formalidad de la relación. Por fortuna Laura registra ese riesgo y toma una posición más firme. Siempre habrá incertidumbres acerca de su capacidad para sostenerse en esa postura, pero creo que por el momento es mejor confiar en ella que entrar en la pauta isomórfica basada en la duda sobre sus fortalezas que podría llevarme a sobreprotegerla aún como terapeuta.

Se recrea aquí una creencia muy extendida socialmente por la cual la persona a quien se le es infiel viene siendo la responsable de la infidelidad. No la hago explícita en la sesión porque no me quiero detener en ese hecho, sino más bien seguir reforzando los recursos personales y de su red para que pueda mantenerse en su decisión. Adicionalmente, en ausencia de Carlos toda conversación al respecto termina siendo especulativa y menos potente para afianzar el cambio. Es bueno decir que no tengo ninguna preferencia por la dirección del cambio en cuanto a si siguen juntos o se separan y al contrario pienso que es posible que en el mediano o en el largo plazo quieran reintentar la unión, pero en este momento me parece que lo fundamental es contribuir a que Laura se apropie de sí y si las circunstancias se dan, tendrá criterios propios para optar alrededor de su vinculación con Carlos.

\section{Recursos de la red familiar y social para retomar su vida personal}

T. Pero ¿de qué otras maneras estás enriqueciendo tu vida, o qué idea tienes?

L. Pues ahorita, obviamente el objetivo es conseguir trabajo.

T. ¿Y las relaciones con la familia de tu mamá en qué están?

L. Mi papá en estos días que pasó lo de Carlos le contó a mi hermana, ella me llamó y la razón por la que se fue a España fue algo 
similar; terminó con una pareja y obviamente no tenían hijos y ella quedó sola, desamparada, sin trabajo, sin casa, sin nada. Entonces me dio muchos consejos, me habló mucho, me dijo: trata de ver por ti misma, piensa en ti, proyéctate, qué quieres hacer con Mario, si es el motor de tu vida, has algo por él. El no tener al lado un hombre no quiere decir que uno sea menos mujer. Hablamos muchas cosas, me dijo que si estaba viniendo a psicología, que tratara de buscar un trabajo que me entretenga. Ya con mis tías me vi hace poco, se enteraron por mí, pero tampoco me dijeron mucho; lo único que dijeron fue que no iba a ser la única mamá soltera del mundo.

T. Están en buen tono contigo.

L. No hablamos tan seguido como antes. De pronto ahora sí siento que es momento de acercarme más.

T. Pero con esos límites de que no se metan en tu vida así como tan directa y abruptamente.

L. Eso es lo que quiero y al final comprendieron un poco eso. Aunque mi familia sí se molestó con lo de Carlos, porque él había hablado con mi hermana que tenía proyectos y eso mismo pasó con mis tías, que lo veían tan decidido.

T. Sí, acá también lo vimos así.

L. Entonces de pronto por eso quieren que yo evite el contacto con él; al contrario de la familia de él.

Considero que hay diferencias culturales importantes acerca de los efectos de la infidelidad y del no compromiso de pareja entre las familias de Carlos y de Laura, pero en beneficio de su autonomía parece que en la familia de ella la alientan como se espera y como ella quizá lo estuvo esperando en otros eventos de su vida. Esas diferencias me parece que están siendo bien manejadas por Laura, quien pone distancias adecuadas con su familia política, como condición para facilitar su desapego. Ello mostraría que ha comprendido bien la dinámica relacional en la que había estado participando y deja ver ciertamente su criterio y su capacidad de decisión. 


\section{Redefinición de las relaciones con la familia de Carlos}

T. Eso es importante, porque quiere decir que la significación que ellos le dan a esos eventos es como que no es un problema sino algo normal...

L. A mi se me hace un poco chistoso, porque casualmente los padres de él tuvieron una experiencia como pareja y sin embargo siguieron, admiro cosas de ellos. Entonces ponen en similitud que lo que pasa acá fue lo que pasó con ellos, pero la situación es distinta. Por eso es que ellos me hablan y me dicen que lo piense.

T. ¿Pero en realidad Carlos no te ha ofrecido que vuelvan y que continúen?

L. No, eso era lo que yo le decía a la hermana de él. Le dije: mira, él no me ha dicho nada, antes lo que quiere es no sentirse culpable...

T. Como si tú fueras de caucho...

L. Exacto y eso es muy difícil.

La expresión "como si fueras de caucho" resume desde mi punto de vista una creencia subyacente en las personas que ofenden a otros y pretenden que todo se olvide muy rápido, quizá precisamente porque descalifican el impacto emocional y el tiempo de recuperación que se requiere para rehacer una relación lesionada, más aún cuando dentro de ella no hay un espacio de metaobservación de lo que ocurre.

\section{Visión de futuro}

T. El punto es entonces ¿cómo en realidad te quieres proyectar? Porque si asi son las cosas, hoy en día eres una mujer soltera, bonita, con un niño de dos años, que está organizada. Y a tus 27 años ¿qué te quieres imaginar para los próximos tres o cinco años?

L. Con mi papá hablábamos; por un lado me gustaría irme a estudiar a España, pienso al mismo tiempo que no es tan fácil llevarme a Mario y que Carlos lo quiera dejar ir. Pero independientemente de eso, la forma en cómo me veo es con mi bebé, 
independiente de mi papá, porque siento que en algún momento puede irse para allá, o así no se vaya quiero tomar mi vida, quiero prepararme más en mi carrera, porque siento que me desconecté mucho de todo.

T. ¿Y acá puedes hacer alguna actualización?

L. Si, hay varias formas de hacerlo, estoy viendo varias posibilidades.

T. ¿Como cuáles hay?

L. Hay muchas academias de diseño, más que todo cursos, especializaciones en la Tadeo. Estaba pensando en que no fuera presencial sino desde otro país, varios compañeros me han hablado de eso también.

T. Ah, o sea que mantienes también esa red de contactos con tus compañeros...

L. Sí, estoy tratando, hubo un tiempo en que me desconecté totalmente, pero si quiero...

T. Activar eso es importante para tu propio alimento emocional y también obviamente para los contactos laborales.

L. Sí claro, pues cuento con buenos contactos en ese aspecto, porque muchos compañeros están volando por decirlo así... les ha ido muy bien y estoy un poco desentendida.

T. Necesitas que te reorienten.

L. Exactamente, eso es lo que pienso. Entonces por el momento me interesa más que todo eso y el trabajo, ahorrar, velar por Mario y estar bien con el bebé, quiero que esté feliz.

T. Y tú también.

L. Sí, señora.

Sigue evidenciándose la consistencia de sus cambios en el realismo; con él visualiza sus posibilidades en los distintos órdenes de la vida.

\section{Cómo posicionarse en la relación con Carlos para ser coherente con la separación}

T. Además porque has tomado muy bien esta situación con Carlos, me parece que la has encarado. 
L. Sí, no ha sido fácil, hay días que me da duro, pienso cosas... a veces piense y piense y a veces trato de no hacerlo. Lo que siento es que a veces me afecta hablar con él, él me pregunta tal cosa y como que...

T. Porque ¿él en qué tono te habla?

$L$. En resumidas cuentas lo que quiere es tener una muy buena relación conmigo; trata de tratarme bien; me dice: "si tú quieres tratarme bien, yo lo acepto".

T. Pero ¿qué es tratarse bien?

L. Porque hay momentos en que al principio me llamaba y yo le hablaba de una forma fea, entonces él me decía: ¿cómo me quieres tratar? y yo le decía, es difícil. Hay días en que tengo equis cosa entonces me llama y le contesto con rabia, como hay otros días que hablamos de Mario.

T. Como que hablar del tema que los une es más fácil que seguir tocando los otros temas...

L. Entonces llegó el punto en que le dije: me va a tocar no hablar más contigo.

T. ¿Por iniciativa de quién?

L. A veces es iniciativa de él y a veces es iniciativa mía, es como parte y parte. Pero no llegamos a ninguna conclusión. Cuando recién pasó eso, llegó un momento en que tuvimos una conversación fuerte y dijo "qué hago acá entonces".

T. Claro.

L. Entonces, con los días, se calmó la situación y me dijo que él me habia dicho eso porque no quería seguir haciéndome daño; me dijo: "no quería ilusionarte más"; que me lo decía así porque asi yo cogía fuerza y me alejaba de él. Yo le dije ¿pero entonces qué? ¿Sí o no? ¿O más o menos? Él me decía que sí, pero que en la realidad la relación de los dos era igual. No siento que sea igual ni que no vaya a ser igual, sino que ya con todo esto que pasó, después de todas las embarradas que hizo...

T. O sea que la forma de quererse ya no da para tener una relación... 
L. Exactamente, en resumidas cuentas me dijo eso. Entonces, obviamente a veces siento que para él es mucho más fácil que para mí, además por las formas de ser. Yo soy mucho más sentimental.

T. Él fue el que decidió hacer las cosas por fuera, en cambio a ti te cayó como un baldado encima.

L. Sí, entonces le dije: "yo me pongo asi en ciertos días porque tantas cosas que habiamos proyectado se esfumaron".

T. La ilusión...

L. Segundo, que nunca me hubieras dicho que ya no me querías igual, porque una cosa es que estuviera aburrido en la relación y otra es que nunca se hubiera acercado a decirme: "ey, mira Laura ya no siento lo mismo"; $y$ tercero que sigas pretendiendo que yo siga ahi; para mi es difícil y hay días que voy a estar mal, pues sinceramente, por mi bienestar me parece que es mejor que hablemos lo del bebé y ya.

T. Exactamente, es lo más conveniente en estos casos. Mientras tú terminas de digerir esta ruptura.

L. Sí, porque hablar del tema es como...

T. Volver a lo mismo, sobre todo si no te está replanteando una reunión de ustedes, sino mantenerse en la ruptura, entonces para qué...

L. Sí.

T. ¿Y él con qué regularidad llama?

L. Casi siempre, está llamando unas tres veces al día.

T. Ah, ¡hartísimo! ¿Y por qué llama tanto?

L. Pues eso es lo que no sé. Últimamente sí ha estado con Mario estas dos semanas. Digamos que también llama por saber cómo le fue en las terapias.

T. Una llamada al día... porque esta invasión ahora es terrible...

L. Sí.

T. Eso hace, si tú no pones un limite, que sin darte cuenta te pongas al servicio de lo mismo, tu pensamiento y tu energía emocional, porque cada llamada implica como volver. Como cuando uno apaga el computador y otra vez vuelve y lo enciende y vuelve y lo apaga, entonces se desgasta, gasta más energía para nada... 
L. A veces de pronto sí fallo también en eso.

T. No, eso no es una falla, es parte de cómo uno maneja una situación de estas para que sea más llevadera y te ayude en el objetivo que ya está planteado de que cada uno toma su lugar. Apenas el niño hable, puede hablar con el niño y para lo demás no se necesita la conversación, porque es otra vez como si no hubiera pasado nada: “¿y ya almorzaste?, ¿ya comiste?, ¿está lloviendo?” Asi vuelven a lo mismo.

L. Sí, realmente a veces es como si nada hubiera pasado y uno no se da cuenta.

T. Ese sería un ejercicio: que hablen una vez al día y ya.

L. Sí, voy a hacer eso porque de todas maneras sí siento que cuando hablo con él, no sé....

T. Por supuesto, eso te roba energía.

L. Sí.

T. ¡Muy bien, has crecido mucho en estos dos meses desde que nos conocimos! Voy a hablar con los colegas.

En mis sugerencias aplico experiencias vividas en los procesos terapéuticos de muchas parejas en conflicto, a las cuales les recomiendo, a veces como tarea, actuar como si en verdad estuvieran separados, asî estén dudosos sobre esa decisión y he visto que logran aclarar de ese modo sus sentimientos, sus proyectos y la confianza en que pueden vivir sin el otro, lo cual a mi juicio es una condición necesaria para mantener relaciones constructivas.

\section{Intersesión}

J. Ha podido hacer distinciones que me parecen muy claves en su evolución personal: la distinción entre sus sentimientos y su postura ante una realidad.

T. Perdón porque yo estaba pensando que sería interesante hacer un equipo reflexivo. Conversemos un poco más y lo programamos si ustedes están de acuerdo.

J. Entonces ha podido hacer esa distinción sin negar sus sentimientos, posicionándose en una realidad, que creo que es bastante 
importante en la estructura del self de ella. La segunda consideración es que en todos los contextos está creando sus límites, su espacio vital y eso genera autonomía y tercero, ha podido ver el rumbo secuencial de su historia; o sea no está detenida en su historia, en qué va a pasar, sino que ella es autora de su propia historia y creo que eso es fundamental también.

A. Yo la veo más empoderada en cuanto a tomar decisiones, incluso el tono de voz está más fuerte, su postura, más erguida, más posicionada en su vida. Como que ya no espera que sean los otros los que le digan qué hacer sino que es ella quien toma decisiones respecto a lo que es mejor para si misma. Eso me parece un cambio bastante significativo, porque como ella llegó, fue viviendo más en función de los otros que son más fuertes y como si ella sola no pudiera. Abora la ruptura que tuvo con su novio es un acontecimiento que la impulsó a darse cuenta que tiene que pensar en ella, sí o sí, ya no como un plan B, que creo que era una historia muy recurrente, como que no la tomaban en serio porque ella no lo hacía consigo misma.

T. Sí, pues no sé si ustedes quieran conversar de todo esto, más también un poco desde el rol de género de cada uno hablar de toda su situación, ayudarle a fortalecer su marco de referencia, porque pareciera que en el entorno, sobre todo de él, hay una tendencia a minimizar la infidelidad y esa postura ambigua de que no estoy, pero le doy la plata, pero no me hago cargo, vivo, pero no vivo...

A. Como si ella se tuviera que acomodar a lo que él le plantee.

T. Sí.

J. Y así como va, va bien, ya salió.

T. Sería ofrecerle una sesión en quince o veinte dias para seguimiento.

Le explico de qué se trata el equipo reflexivo y con su consentimiento pasamos del otro lado del espejo para observar la conversación de los miembros del equipo, J y A. 


\section{Equipo reflexivo}

A. Me siento muy contenta de venir acá, al ver a Laura tan clara en que hay que poner limites. Me parece que ha sido respetuosa al ponerlos, que han sido de tal forma favorables frente a la situación; es muy importante porque es parte del ser una mujer mucho más decidida. Ya la veo como una mujer más guerrera, en función de sí misma y de su propio hijo.

J. Sí, yo la percibo así. Eso es muy importante porque ella está frente a una situación que la hace más digna. Hace la distinción entre sus sentimientos, su corazón y lo que pasó y exige su dignidad. Algo muy importante para ella son los términos en que queda con Carlos. Se van generando espacios fundamentales donde dice: "yo soy yo" y tienen que respetarme en esa consideración. Creo que ha crecido la fortaleza en su capacidad para pensar. Si ella sigue por ese lado, creo que se dibujan muchas posibilidades en la vida que la llevarán en su propio destino. Eso es lo que me parece muy claro de ella, está asumiendo los límites necesarios para que se entienda su posición personal y eso me parece clave para su autonomía. La historia de ella estaba atascada, no podía avanzar y ahora siguió su curso. Me parece que es de felicitarla a ella y por supuesto la relación con su terapeuta ha sido destacable.

A. Con lo que dices, Laura es una mujer más sabia respecto a que antes otras voces le decían qué hacer con su vida, ya no.

J. Ahora es su propia voz, quien soy yo para mi misma. Yo me quedaba pensando... si su hijo la viera la admiraría porque le dio la capacidad de entender la vida, porque están preparados para lo que el destino les depare.

A. Y respecto a las relaciones de pareja, lo que ella quiere está abora más claro.

J. Sí y eso viene en la evolución de la misma pareja. Se queda o se va. 
A. Hay una frase respecto a eso que es "nosotros aceptamos el amor que creemos merecer".

J. Entonces ahora llega al mundo preparada, asi que la felicitamos por eso.

\section{Cierre}

T. ¿Cómo te cae todo eso que piensan los colegas?

L. Pues lo hacen sentir a uno muy bien, de verdad que uno no se ve así, uno a veces no es capaz de ver todas esas cosas que uno mismo hace o que piensa; de verdad me siento muy contenta de haber escuchado eso y sobre todo esa última parte en cuanto al amor, que uno a veces se limita. A mí con Carlos me pasaba eso, que habia muchas cosas con las que no me sentía contenta, sin embargo me las aguantaba. Ahorita caigo en cuenta de todo eso $y$ digo no, no lo aguantaría.

T. Bueno, pues abi lo tienes para que lo sigas asimilando, apropiándote y reforzando para que sea también una fuente de fuerza.

L. Si, también, sí, señora.

T. Creo que vamos cumpliendo el objetivo por el cual viniste acá. Si quieres programamos una sesión por abi en quince días, como para evaluar cómo estas y quizá ir haciendo un cierre, por ahora. Ya nos conocimos, ya estoy ahí, acá o donde sea, porque tampoco se trata de que te quedes acá. Nosotros muy contentos de verte, pero la vida continua ¿icierto?

L. Sí, sí, señora.

T. Y si quieres venir con tu papá, también sería muy bien, como para terminar de concretar los cambios que ustedes muy bien han empezado a hacer.

L. Listo.

T. Felicitaciones, que te vaya muy bien.

En su expresión no verbal se evidenció el efecto potente de las palabras reafirmantes de los colegas. Yo tenía la sensación de la tarea terminada, pero dejé abierta la posibilidad de seguimiento, pues con la experiencia me he dado cuenta que es valioso para los consultantes 
saber que el hilo vincular establecido se mantiene como un recurso adonde acudir en caso de necesidad, bajo el principio de que una de los efectos de estos procesos terapéuticos es la naturalización de las dificultades de la vida y de la posibilidad de pedir ayuda cuando se requiere.

\section{Síntesis de la evolución de la subjetividad en el caso de Laura}

La secuencia del caso muestra cómo de una narrativa de sí misma centrada en el estancamiento personal, la espera de compañía y validación por parte de su pareja y de su familia, el encierro en el mundo de la crianza y la pérdida de su rumbo vital, acompañado de sentimientos de frustración, tristeza, irritabilidad e impotencia, se fue llegando a una descripción de sí misma como persona capaz de autodeterminación para redefinir principalmente el contexto de una relación de pareja que ella vivía como una suerte de prisión protectora y con ello apareció su fuerza personal para optar por una forma de vida conforme a sus deseos.

Los dispositivos del cambio utilizados se pueden describir como sigue: en primer lugar, hice una aproximación lo más completa posible a los hechos de su vida y a su manera de vivirlos en los sistemas de relación y de significación, con el fin de visualizar su medio de vida y captar su forma de experimentarlo para lograr ponerme en sus zapatos. Con esa vivencia que definí como atrapamiento y estancamiento, identifiqué tres referentes fundamentales a partir de los cuales organicé el proceso: su propia vivencia de sí misma, su relación de pareja y su relación con el padre, la madre y la hermana, principalmente. La hipótesis subyacente fue la misma que motiva este trabajo, es decir, desenredar un self atrapado en un contexto vincular donde tenía poco espacio para ser ella misma por escasa validación, reconocimiento, expresión de afecto y de confianza en su capacidad de autonomía, a lo cual se sumaba un tácito desencanto de su pareja, en quien había encontrado antes del embarazo un lugar de reparación. Esa fallida posibilidad reactivó la misma pauta ambigua de amor condicionado y la sobrecarga de tensiones desencadenó la crisis que la llevó a terapia. 
Pero quizá el dispositivo más potente fue la búsqueda de recursos internos mediante el acceso a experiencias que le fueron desafiantes, a las imágenes de la madre basadas en la representación encarnada en su historia y a la revisión de sus criterios de éxito contrastados con las expectativas que leía de sus parientes. Adicionalmente estuvieron las confrontaciones directas a sus creencias, a sus actitudes y a su postura en las relaciones familiares y de pareja.

Dado el contexto del caso y la unanimidad del sistema terapéutico (consultante, familiares y terapeuta) en la utilidad de enfocar el trabajo en Laura, el padre y el compañero tuvieron en la terapia un rol sobre todo de testigos, fuentes de confrontación y polos de realidad. No obstante, puede decirse que por el efecto de sistema, hubo también un impacto en su subjetividad en la medida en que por el reposicionamiento de Laura, tuvieron que también modificar su lugar en las relaciones y con ello seguramente percepciones y creencias de cuyos cambios no se alcanzó a tener información por el cierre del proceso terapéutico.

\section{El caso de Julián}

\section{Pre-sesión}

La psicóloga responsable de la recepción presenta el caso de una familia remitida por el colegio por preocupaciones sobre el comportamiento del niño de ocho años, que tiene dificultades de adaptación en los ambientes escolar y familiar y ha sido diagnosticado con un trastorno por déficit de atención e hiperactividad TDAH. Informa además que el niño ha estado en tratamientos diversos de orden psicológico y también ha recibido la medicación psiquiátrica respectiva. El sistema familiar actual está compuesto por la madre, el compañero de la madre y padrastro $(\mathrm{P})$, Julián como paciente identificado y una niña de seis años adoptada. De la primera unión de la madre hay tres hijos: un hijo de 10 años que vive con los abuelos, Julián y un niño perdido.

El análisis de la remisión me conduce a varias consideraciones: 1) Es una familia recompuesta, con una segunda unión de la madre y ello me invita a pensar en la reorganización de la estructura de esta 
familia. Este aspecto es clave en tanto que la reorganización de la estructura familiar tiene que ver con la asignación de funciones y roles para conformar la "nueva familia" y cuando no se logra esta nueva organización se configuran contextos familiares difíciles, los cuales están relacionados con síntomas en algunos de sus miembros. 2) El niño está diagnosticado con TDAH y esta lectura me anuncia una lógica médica en el manejo del caso. Por mi experiencia profesional sé que este tipo de intervención biologiza el problema y no se resuelven los procesos psicológicos necesarios para la evolución en todos los sistemas. 3) Evoco además experiencias anteriores con casos similares en donde la definición del problema se centra en el niño y en su sufrimiento debido al atrapamiento en la situación. Pienso en él como sujeto humano, en su self como persona, en los procesos posiblemente difíciles de sus aprendizajes y de sus adaptaciones sociales en el seno de su familia y en la escuela. 4) Reconozco también las dificultades por las que puede estar atravesando la familia ante las demandas de la institución educativa para resolver el problema y de igual manera las preocupaciones del sistema escolar para manejar la situación del niño.

En síntesis, con estos constructos me hago los siguientes interrogantes: ¿cómo es la estructura familiar actual y cómo funciona?, ¿cómo están definiendo el problema?, ¿cómo es la dinámica interaccional de los sistemas presentes en esta problemática y ¿cómo se encontrará emocionalmente el niño en esta situación?

\section{Primera sesión}

Asisten el niño, la madre y el padrastro.

\section{Definición del contexto de ayuda3}

T. Buenas tardes a todos. ¿Cómo se llama?

N. Julián.

M. Buenas tardes.

3 Convenciones: T: Terapeuta J. Estupiñán; M: Madre; N: niño Julián; P: Padrastro 
P. Buenas tardes.

T. Qué bonito nombre. Antes de comenzar quiero comentarles cómo trabajamos en estos consultorios; Para empezar deseo presentarme, soy J. E., psicólogo clínico y docente investigador. En este caso estoy atendiéndolos porque estamos haciendo una investigación con familias. Además de ofrecerles el servicio de ayuda psicológica, ustedes nos pueden ayudar como familia en ese proceso de investigación. Todo ello si ustedes están de acuerdo.

M. Sí, igual la señorita ya nos había comentado.

T. Contamos con dos psicólogas asistentes en el equipo de trabajo y pueden contar con ellas; en este sentido si deciden participar en esta investigación deben expresarlo en un documento para registrar dicho consentimiento.

M. Sí.

P. Sí, no hay problema.

Defino las condiciones del contexto institucional como principio ético de claridad para los consultantes y para que opten en libertad; de igual manera anuncio que todo queda protocolizado en el respectivo consentimiento informado. Soy consciente de que si no desean participar en el proceso de investigación, igualmente serán atendidos. De igual manera inicié con el reconocimiento de la bondad del nombre de Julián, en tanto que deseo un contacto mucho más cercano con el niño, esto como parte de un enganche en la relación con él como medida de protección para con él, quien es el paciente identificado.

\section{Conocimiento de la organización familiar y primera indagación del motivo de consulta}

T. ¿Cuál es el motivo de su consulta?

M. Porque estamos un poco preocupados por la actitud de Julián.

T. Ab ya, ¿Julián es, entonces el motivo de su consulta?

M. ¡Sí!

T. Y para usted... (Dirigiéndose al compañero de la madre)... ¿Considera este el motivo de consulta?

P. Pues con lo que se ha visto, sí. 
T. Bien, están de acuerdo; antes de hablar de sus preocupaciones, deseo conocer un tanto la familia ¿Cuántos años tiene Julián?

N. Ocho.

T. Julián, cuénteme, ¿dónde estudia?

N. En el Colegio A. Ramírez.

T. Y ¿ cómo le va en el colegio?

N. Bien.

T. ¿Qué curso hace, en este momento?

N. Segundo.

T. ¿Me imagino que vive con la mami?

N. Sí.

T. ¿Y con el compañero de su mamá?

N. Sí, también.

T. Bueno, quiero conocer los miembros de esta familia, entonces. Julián que tiene ocho años y otros dos, para un total de tres hijos; si he entendido bien, todos ellos de una primera unión de la mamá, ¿estoy en lo cierto?

M. Sí.

T. ¿Cuántos años tiene su hijo mayor?

M. 10.

T. ¿Y se llama?

M. Alberto.

T. ¿Y luego esta Julián?

M. Sí y mi bijo Felipe (F).

T. ¿Todos viven con usted?

M. No. Mi hijo mayor vive con los abuelos, Julián con nosotros y F que me lo quitó el ICBF, es como si estuviera muerto y además vivimos con una hija adoptada.

T. ¿Y su primera unión cuánto tiempo duró?

M. No convivimos con el padre.

T. Y cuánto lleva la convivencia con $P$.

P. Hace cuatro años.

T. ¿Y cómo les ha ido en su convivencia?

N. Bien. 
De la información obtenida me llama la atención la manera como está distribuida la familia, en el sentido de la situación del niño ausente en el ICBF, el hecho de que el hijo mayor esté con los abuelos y que la madre y su compañero actual vivan con Julián y una hija adoptada; las razones de este modo de configuración familiar son un motivo de indagación que irá quedando claro en el decurso del proceso psicoterapéutico. Al respecto tengo la impresión de una primera familia desintegrada por razones que aún desconozco y de una segunda familia que se encuentra en un periodo de reorganización y me planteo la relación del síntoma con los procesos vividos en esa historia familiar.

De igual manera clarifico que la primera unión de la madre, de la cual tuvo los tres hijos, no fue formalizada y veo que la unión formal con el compañero actual le da configuración específica a esta familia; me llama también la atención la aparente sustitución de la ausencia de Felipe por la de una hija adoptada y de igual manera me sorprende para bien la respuesta del niño en torno a la convivencia en el entorno familiar. Ubico la familia en un ciclo de vida con hijos escolares, con cuatro años de constitución e intuyo las necesidades de ajuste de este sistema. Al respecto me pregunto qué relación existe entre el niño como síntoma y los posibles dilemas de adaptación de este sistema. Igualmente me inquieta la historia, aun no revelada, de cómo se sustituyó la ausencia de Felipe, su hijo menor, por la hija adoptada.

\section{Redefinición del problema: del niño problema al problema de las relaciones y sus modalidades de vinculación emocional}

\section{T. ¿Qué es lo que pasa con Julián?}

M. Está un poco agresivo, entonces no sabemos por qué está agresivo. Acá está la carta de la psicóloga del colegio que dice los motivos porque nos mandan a terapia.

$P$. Si, básicamente que no está haciendo caso, no respeta la imagen de autoridad y hace lo que quiere, irrespeta a la niña, a los profesores; hemos ido este año varias veces al colegio.

M. ¡No! Es que antes era un poco agresivo, pero los últimos años como que se volvió más. 
P. Está bien un tiempo y cae, nos tiene en ese jueguito.

M. Nos dicen que lo metamos en academias de la hiperactividad y todo eso.

T. Esa es una manera de ver la situación, pero hay otras maneras de pensar de Julián que ayudarían a comprender mejor la situación.

M. Desde pequeño es agresivo y en el colegio más todavía.

T. ¿Y desde pequeño como vieron ustedes la situación?

M. No lo metimos a jardín porque no lo podía meter en ninguno, una señora me lo cuidaba, prácticamente hasta los 5 años. No tuvo jardín y ahi nos dimos cuenta por los psicólogos, que lo sacaban de las instituciones educativas al mes, no ha podido tener todo un año completo en la misma institución.

T. O sea es una historia con dificultades. ¿Y esa historia por qué no se cambió?

M. No sé, pero la vamos a cambiar.

T. Esa postura es un buen comienzo. Porque ese tipo de historia es como un rótulo que le colocan a los niños con ciertas dificultades.

P. Si y a uno ya le parece normal y todos participan que él es así.

M. Sí, uno llega a la casa y de una es ¿dónde está que no lo sentimos?

P. Sí ya lo hemos encasillado.

M. Y del colegio todos los días nos llaman.

T. Si, como usted dice está encasillado. Me imagino que a Julián no le gusta ese encasillamiento...

N. No.

T. ¿Cómo se siente cuando le dicen que es un niño que molesta?

N. Mal.

T. ¿Para que le digan así, cómo se comporta?

P. Ahi está él haciendo esas cosas implícitamente (el niño se levanta del asiento y se distrae en la sala), ese es el problema, busca siempre llamar la atención.

M. Distraído.

T. Lo cual quiere decir de otra manera que requiere ser escuchado.

P. No, yo creo que es su comportamiento actual, porque siempre hay reglas por respetar, yo siempre he dicho eso y no sé, las hice claras o de una forma que para el sean claras como toda la gente. 
T. Si entiendo bien... para usted es el modo de educarlo.

P. Sí, porque cuando se le ha dicho que debe hacer tal cosa, la hace.

T. ¿Cómo se ha dado cuenta de eso?

P. Pues lo que hace, la familia de pronto lo ha llevado a ese comportamiento; ha hecho falta organización y ser coherente con lo que se dice, eso es lo que yo veo. Igualmente no es solo asunto de ella, sino que él aprovecha eso y además, quejas de vecinos, colegios... para mi el tema es esos acuerdos. (Refiriéndose a reglas).

T. Para usted el tema sería acuerdos para educarlo sin ir a extremos de fuerza.

P. Una cosa es orientar, otra golpearlos, pero una forma coherente.

T. Usted ¿cómo lo definiría?

M. Él dice que la regla y bueno yo no la hago cumplir, pero no lo puedo castigar un día, sino una hora al día.

T. Entonces, ¿cuál es el problema para usted?

M. Es que el problema no es mío, el problema es de él. Uno le puede decir las cosas de un buen modo, pero no hace caso, es imposible, es más su distracción, así se le pongan reglas.

T. ¿Y entonces cómo educarlo?

M. Pues ya está con medicamentos, pero veo que el problema no es de nosotros.

T. Pero entonces cómo poder educar a su hijo, porque usted define el problema como algo de él.

M. Es que uno está con él todo el tiempo y eso cansa.

T. Una cosa es que esté cansada, y eso lo entiendo, pero otra cosa es que usted señale que el asunto está solo en él.

M. Como le dije a él o cambia o internado.

T. Eso es como una especie de amenaza.

M. Sí.

T. ¿Cuál sería la consecuencia de amenazarlo?

M. Pues que cambie.

T. Y si no cambia...

M. Sí, y lo voy a meter allá.

T. ¿Y cómo ha comprendido el cambio con la amenaza? 
M. No lo amenazo son cohibiciones. Esta semana se ha portado bien, yo ni sé cuál es su problema, porque todos los exámenes dicen que es normal pero no se comporta así.

T. Si yo dijera que Julián necesita un modo diferente de relacionarse con ustedes ¿qué dirían?

M. De pronto, pero él agrede.

T. Una posible manera de leer esta agresión es que es su manera de solicitar reconocimiento, amor, consideración, por supuesto no es la mejor forma.

M. Sí, exacto.

T. ¿Cómo queda para ustedes la definición del problema? ¿De qué modo el comportamiento de Julián está relacionado con la manera como los adultos se relacionan con él?

M. Porque de pronto no le he prestado atención.

T. Es posible que Julián necesite una comprensión diferente cuando se relacionan con él. ¿Qué piensa Julián?

N. No sé.

T. ¿Qué piensa de lo que estamos comentando? Veo que están en una posición difícil donde condicionan a Julián en su modo de comportarse, pero esto no funciona; entonces pienso qué pasaría si en vez de condicionarlo, intentan entenderlo mejor en su comportamiento; porque la situación es muy difícil, es como una encrucijada, si se comporta mal lo castigan y si se comporta bien entonces lo califican de un niño raro. Muy difícil su situación Julián.

M. Conteste papi.

T. Entonces (dirigiéndose a Julián) no sabe a veces cómo actuar, ¿qué siente?, ¿cómo le hace sentir esta situación?

N. Que está mal.

T. ¿Está mal qué?

N. Yo.

T. Eso es relativo porque si hace algo distinto está mal y si no, está mal también, entonces no sabe cómo comportarte o ¿si sabe cómo hacerlo?

N.Sí. 
T. Entonces cuando se comporta bien ¿cómo lo hace? ¿Cree que lo van a castigar?

N. A veces sí.

T. Claro, porque el modo cómo le tratan no parece ser tan claro.

$N$. Una vez le casqué a un niño del colegio y me castigaron.

T. ¿Y cuando está castigado cómo se siente?

N. Bien, cumpliendo.

T. ¿Se libera de la culpa de haber hecho algo malo?

N. Sí.

T. ¿Y lo premian por hacer cosas bien?

N. Sí, a veces me dejan salir un rato, al parque o algo.

T. Por lo general a los seres humanos no nos gusta el castigo; entonces es como si quisiera quitarse el castigo, ese rótulo del que hablamos.

N. Sí.

T. ¿Por qué quisiera quitarse el rótulo?

N. Sería chévere.

T. Obvio porque es una persona normal y el rótulo incomoda. ¿Está de acuerdo en que trabajemos a solas con sus padres?

N. Sí.

(El niño es sacado de la sala para poder profundizar en la dinámica del sistema parental).

He conducido el proceso para evaluar el síntoma y veo claramente que está relacionado de un lado con los estilos personales de vinculación de la madre y el padrastro con el niño y su relación con las dificultades en la organización del sistema parental. Entiendo que la madre y el padrastro son parte del problema y que el contexto escolar hace parte de un sistema de descalificaciones para con el niño. Complementariamente evalúo la postura del self del niño en su dimensión cognitiva y emocional respecto a su situación. Ante la postura de los padres y como medida de protección para el niño decido hablar a solas con los padres con el objetivo de redefinir la visión que tienen del problema centrado en el niño y redefinirlo de manera interaccional. 
He podido confirmar que la definición del problema, como era de suponer, está centrada en el niño como paciente. Así mismo, los padres tienen como referente para el manejo de la conducta de Julián una visión educativa y se centran en la lógica de suponer que con reglas y control se resuelve la situación; al respecto veo que el modo de vinculación de los padres con el niño está relacionado con una jerarquización de la postura de los padres y que la regulación del afecto requiere ser modulada para equilibrar los altos niveles emocionales negativos de los miembros del sistema, evidenciados a través de la rabia y el miedo. Estos estados emocionales se intensifican en la medida en que se mantiene la definición del problema en el niño.

En la medida en que avancé en este espacio de la sesión, busqué la posibilidad de redefinir el problema en términos interaccionales y se logró una motivación hacia el cambio de esa historia de rotulación; de igual manera se observa una disposición para el cambio de la postura rígida y controladora de los padres en torno a las posibilidades de reconocerse en la interacción con el niño.

Me conmueve la situación del niño que está situado en una paradoja tal que si cambia es raro y si no cambia, es lo esperado; ante esto intento modelizar el self del niño de tal manera que potencie su capacidad de actuación y pueda lograr un mínimo de comprensión de su capacidad como sujeto social y como persona. Esto puede estar asociado a las ideas de Bateson en el sentido del aprendizaje en contexto, de tal manera que intento que el niño se conozca a sí mismo en el contexto de las relaciones y que su subjetividad movilice el cambio de posición en el sistema de las relaciones con los demás. Puedo también entender el constreñimiento de la libertad del niño y deseo que el niño sea considerado una persona reconocida y valorada por los demás; por eso intento producir una conversación reflexiva con el niño para movilizar su self en presencia de los padres.

A partir de estas consideraciones hipotéticas creo necesario, al evaluar la postura rígida del sistema parental, tomar una medida de protección con el niño y lo invito a salir de la sala para poder profundizar con los padres sobre las tensiones como sistema parental. 


\section{Continuación en la redefinición del problema a partir del cuestionamiento de la epistemología de los padres. La armonización de estilos y expectativas de los miembros de la pareja}

T. ¿Qué piensan de lo que estoy hablando con Julián?

M. No sé.

T. Fíjese como él está conversando de una manera diferente. No se necesita imponerle cosas para señalarle un camino. La pregunta es ¿qué piensan de lo que estoy diciendo?

M. Como bajarle más (el tono) cuando le hable.

T. ¿Cómo fue usted educada y amada por sus padres?

M. Yo tuve a mis dos papás. Mi papá bien anticuado.

T. Y aprendió que el rigor funciona.

M. Sí.

T. ¿Y lo repite con Julián?

M. Sí, hay veces.

T. Aunque funcionó con usted, no sé si ocurrirá lo mismo con Julián.

M. Sí, es buscar otro método.

T: Así es, y ¿qué piensa P?

P. La idea es como el tema de comunicación, cómo hacemos llegar el mensaje, le debemos trabajar a eso. Queremos lo mismo pero lo decimos de formas diferentes, a veces como que no llegamos a nada, abi estamos fallando y bueno lo común es que queremos sacarlo adelante. Pero es comunicación y lo que siento con los otros hijos es que nos ponemos a la defensiva, queremos algo pero no hemos acordado para que el mensaje quede claro.

T. Claro, esos mensajes deben acordarse, decimos que es hiperactivo como si la gente fuera un robot y no se analiza el sentido de los mensajes.

M. Sí, de pronto lo que tenemos es confusión.

T. La comunicación puede ser confusa y pueden llegar a descalificarse entre los dos como padres del niño. Es muy importante saber cómo es esa comunicación entre ustedes.

M. Mala. 
T. ¿No hay acuerdos?

M. No.

T. ¿P usted está de acuerdo con esta afirmación?

$P$. Sí, el tema son los genios, que a veces con ella, es que es asi y ya. Es terca, como que se cansa de lo mismo, porque se supone que se botan ideas, se hacen respetar, se miran, se analizan, pero el tema es la oposición. Sé que si digo algo es para amargarme, entonces como que mejor he optado por callarme, no estoy diciendo que siempre uno tenga la razón pero veo cosas que digo no son así, entonces en últimas me quedo callado y ya. Es eso, no hay buena comunicación. El tema es hablar y escuchar, no se puede siempre hablar, se debe aprender a escuchar. Ya me cansé de ir siempre contra esa roca.

T. ¿Y eso cómo le hace sentir a usted?

P. Pues impotente. En mi trabajo hago cosas y en la casa no puedo.

T. ¿Y cómo maneja las cosas así?

P. Hay momentos que estallo. Tengo que decirlo.

T. Es un juego peligroso para ustedes como familia y para Julián.

P. Sí, es comunicación y a veces no sabemos qué hacer con lo de Julián.

T. Mejor dicho Julián se constituyó en un foco de discusión para los dos.

P. De una u otra forma sí ha sido así, en los últimos meses eso ha sido más continuo.

T. Julián es el motor de la discusión entre ustedes; en vez de ser un punto de unión, es de confusión. Veo una tensión entre los dos que revela sus dificultades en la relación.

P. Sí, a veces uno no lo puede hablar.

T. Pero esta manera de proceder no le da resultado.

P. Sí, es peor. Yo le digo hagámoslo de esta forma, no es bueno que siga viendo televisión, pero lo digo y otra vez.

T. ¿Y esto sucede en presencia de Julián?

$P$. También y salen cosas que no deberían salir. Cuando cruzamos la línea del respeto es fuerte, es eso no escuchamos, somos cerrados en que es asi y cuando no estamos hablando nos desbocamos, no 
somos familia y empezamos a mirar un poco más allá de gente que ni siquiera pertenece a nuestro círculo de vida.

T. Involucrar a otras personas que no pertenecen al sistema.

P. Si en mi casa tengo un grupo de gente donde hay comunicación, respeto y aprecio, no habría eso.

T. Entiendo que es algo que está afectando la vida cotidiana en la pareja.

P. Claro, claro, ya no lo notamos, pero sí. Ya que estamos acá hay que decirlo, porque la idea es llegar a la raíz y uno de los problemas es lo que se ve en la casa, que es no se la deje montar, dele en la jeta a todo mundo o si ve que nos irrespetamos igual, el replica.

T. ¿Qué piensa usted?

M. Pues de pronto si tiene razón en algunas cosas.

T. En el análisis que él hace puedo comprender el orden de las tensiones que tienen ustedes. ¿Para usted cómo es la tensión?

M. No, no me parece, él siempre me echa la culpa a mí, pero él no ha contado que viene cada mes. Usted se imagina yo un mes con él y llega solo a pegarse al celular, computador, no colabora, yo le digo ¿a qué viene?

T. Entonces también está molesta y no está siendo escuchada; por lo tanto usted no es escuchada, él no es escuchado y Julián tampoco. Cada cual en su propio mundo sin ser escuchado. Comprendo la necesidad que usted tiene de ser escuchada.

M. Pues claro, llega cada mes y no hace nada y solo es regañe y regañe y es que no somos sus empleados.

T. Estamos de acuerdo, usted está siendo muy sincera. ¿Qué pasaría si los dos se ponen de acuerdo? Pienso que le iría mejor a Julián.

M. Sí, pero igual el comportamiento de Julián venía desde antes.

T. Quizá tampoco se entendian madre e hijo.

P. Claro que el comportamiento ha cambiado muchísimo, porque cuando recién salíamos era imposible Julián en la familia, todo, entonces sí ha habido una mejora, porque estamos en un momento de transición en que no queremos volver a lo de antes, porque era terrible, de una u otra forma se ha arreglado y hay un cambio. 
M. Es que él se quedó con mi mamá; yo nunca estaba y ahora que estamos con él ya es una familia.

T. Ustedes tienen la respuesta a lo que le pasa al niño, es un problema de organización de la familia, de acuerdos para llevar mejor la vida familiar. Quisiera saber ¿qué estamos comprendiendo en esta conversación?

M. Que tenemos que cambiar y bajar la guardia. Igual es un cambio radical en todo. Porque si él no cambia esa actitud yo lo llevo a un internado.

T. Sí, pero si es llevado a un internado no se libran las tensiones.

M. No, pues llegado el momento del internado, acá separados y cada uno por su lado.

T. Entiendo que eso resolvería la situación para Julián, no para ti.

M. Pues yo viviría más tranquila.

T. ¿Entonces hasta qué punto está dispuesta en hacer cambios?

M. Pues ahora esto y si veo que no hay mejoras, yo la verdad...

T. Esa es una manera de condicionar el cambio, porque presiona a Julián de un lado y su esposo del otro, no sé si se lograría así el cambio de la situación familiar. ¿Estaría usted dispuesta a hacer cambios por su hijo?

M. Yo estoy dispuesta, pero si veo que no hay cambios pues no, es mi forma de ser, yo reconozco que soy explosiva, tremenda.

T. Es una manera de describirse, habría otras. ¿Cómo es la vida para usted sin Julián?

M. Pues yo no quiero pero, es que ya no más, yo no me lo aguanto.

T. Entiendo su incomodidad, sin embargo no deja de ser su hijo.

M. Sí, pero igual él mejora y cambia, pero si le hablo desde mi embarazo era tenaz, me dio unos golpes, vengo con él hace años en lo mismo.

T. Es como si Julián fuera un karma para usted.

M. Sí a veces pienso eso, de pronto estoy actuando mal porque es mi bijo, pero no me lo aguanto.

T. Un karma se puede resolver negativamente o positivamente, es una decisión personal, ¿qué quiere usted en esta ocasión?

M. Pues yo quiero que todo sea positivo. 
T. Para eso hay que disponerse. No va a haber cambio mientras uno no esté dispuesto a cambiar. ¿Qué piensa de la afirmación?

M. Que es cierto.

T. Es importante reconocer que usted ha tenido una vida difícil, que usted puede cambiarla y es una posibilidad que le brinda la vida, en sus manos está la solución.

M. Sí claro.

T. Y usted P ¿̇cuál es su posición?

$P$. Estoy dispuesto, porque es lo mismo siempre.

T. ¿Por qué estarían dispuestos?

M. Pues porque ya llevamos cuatro años y la idea es un hogar para Julián.

T. ¿Y usted?

P. Sí claro, para estar tranquilo.

T. Quisiera saber cómo es su relación con Julián.

P. Variable, bien, mal. Yo no soy el que está abí venga papito, pero no estoy como ella quisiera, le reviso tareas, es un poco cansona por el tema del comportamiento.

T. Entonces hay desacuerdo entre los dos para manejar la situación con Julián.

P. Exacto.

T. Hay varias situaciones por resolver: el modo de interactuar con Julián, sin embargo hay que resolver la situación entre ustedes tanto como esposos y como padres, es lo que hasta el momento hemos observado.

M. Sí, porque si no estamos de acuerdo le puede afectar a él.

Configuro varias hipótesis hasta el momento. Identifico claramente una triangulación de la relación madre-padre-Julián, situación que se mantiene en un orden de desacuerdos entre ellos como padres y responsables de la vida familiar. De igual manera observo dos historias que quieren ser impuestas la una sobre la otra y dos maneras de ver la vida; se hace necesario una configuración de acuerdos para consolidar la estructura parental y familiar; reconozco que han hecho esfuerzos 
para lograrlo y en este sentido la ayuda va a ser muy importante para la continuidad de esa historia.

La estrategia central del cambio está asignada a movilizar los estilos personales para consolidar la estructura del sistema parental y permitir un acople emocional e interaccional entre sus miembros; al potencializar el sistema parental, revertirá en el bienestar del niño y en la coherencia de acuerdos para manejar el entorno.

Creo importante tener como eje central los procesos subjetivos de cada uno de los miembros del sistema y lograr con un proceso intersubjetivo consolidarlo y generar más autonomía para manejar las emergencias en la crianza de sus hijos. Estoy muy atento a las historias de vida, las cuales creo que no determinan la realidad presente sino que la están condicionando por sus miradas aún en el pasado. Utilizo como estrategia el relato que permite reorganizar el sentido de la vida de cada uno de ellos en el contexto de la pareja actual y movilizo el self, cada uno en el marco de un sistema interaccional que los organiza y les da sentido.

\section{La elaboración de una concepción esperanzadora de la vida familiar como cierre de la sesión}

T. Quisiera finalmente saber un poco de sus historias personales y en ese sentido, cómo fueron educados en sus familias.

M. Peor que la educación de Julián.

P. Pues en mi casa era más duro, todo era sumamente estricto.

T. Se encontraron dos modos de crianza difíciles en esta historia que están construyendo; veo la necesidad de inventar una nueva historia al respecto. ¿Cómo quieren educar a Julián?

M. Es que a eso voy. Él quiere crear uno que no..., él no tuvo infancia... él me lo quiere tener (a Julián) como militar.

T. ¿Estaría usted dispuesta a crear uno nuevo con su compañero?

M. Sí, porque ni el de él, ni el mío.

P. Es que ella se va al extremo e irrespeta. Para míno es nada del otro mundo decidir que a las 8 pm se acueste a dormir, son cosas básicas de convivencia. ... Tú dices que son cosas tenaces pero es normal flaca. (Julián ya se encuentra en la sala y se levanta de la silla). 
M. Pero yo ni lo dejo salir a la calle. Nunca sale porque como siempre sale y se convierte en un problema.

T. Claro ambos tienen la razón, pero son puntos de vista diferentes y lo importante es crear un nuevo modo de educar. ¿Han entendido algo más de Julián que no habian entendido antes o con otros especialistas?

M. De pronto es el conflicto, porque siempre hablábamos de él y nunca de nosotros.

P. Ya se había tocado, pero cada vez es problema. El problema es de los dos, lo que estamos haciendo.

M. No y no ha cambiado, o ha cambiado poco a poco.

T. Bien. Y para usted.

P. De una forma u otra ya habiamos tenido estas conversaciones, pero no.

M. Pero es que siempre hemos buscado el psicólogo para esto, no para nosotros.

T. ¿Y hoy qué pasó?

M. Hoy estamos en la terapia familiar y no es solo lo individual.

T. ¿Cómo le parece la modalidad de hoy?

M. Chévere, porque así nos ponemos de acuerdo.

T. ¿Y para usted?

P. Pues creo que es muy sana, sobre todo para que avancemos.

T. ¿Cuál sería una idea que hoy les fue útil para avanzar en su historia personal y familiar?

M. Pues lo del cambio porque pensamos diferente.

$P$. Fue haber venido personalmente, vine a acompañarlos, lo de siempre, pero nunca habia estado y que pereza lo que hacen con ella, pero lo de hoy fue como que, entremos y creo que funciona, es la comunicación, es importante saber escuchar.

T. ¿Entonces esperanza es lo que llevan hoy?

P. Sí, claro, como que yo también le voy a meter, tengo que cambiar algunas cosas, ahora todo tiene sentido.

T. ¿Y qué fue lo que le dio más sentido?

N. Lo del cambio de todos. 
T. Muy bien. Les propongo la siguiente ruta, vienen los dos padres solos a la siguiente sesión sin Julián; luego nos vemos con Julián y la mamá, y por último los tres de nuevo. Por ahora les sugiero que no hablen más del tema.

Desde el punto de vista estructural, especialmente desde la teoría de Minuchin, creí importante organizar una estrategia en donde puedan establecerse con claridad los acuerdos y transacciones entre los padres con relación a la forma de manejar el comportamiento y educación del niño; en este sentido se tuvo en cuenta los procesos de diferenciación de los individuos y su relación en el marco de los acuerdos para movilizar la vida familiar. De igual manera identifico en las historias de la madre y de su compañero experiencias fuertes en sus historias personales de crianza y especialmente intuyo una historia de descalificación en la madre, la cual me hace posicionarme desde este momento con consideración y reconocimiento de sus dificultades. Organizo en consenso con ellos las estrategias básicas de movilización del proceso y pienso que es importante iniciar con la solución de las tensiones en el sistema de padres para que una vez adecuado este sistema podamos comprender mejor la naturaleza del síntoma de Julián; de igual manera me queda claro que hay una historia previa de la madre y el niño que se hace necesario de estudiar, así como hacer intervenciones directas con el niño en presencia de la madre para re posicionar la capacidad de Julián como ser humano y como persona y generar en él su capacidad autonómica de acción en sus procesos de adaptación social.

\section{Segunda sesión}

Asisten la madre y el padrastro.

\section{Elaboración del sentido ético de los cambios de su rol parental y su relación con el niño}

T. ¿Cómo les acabo de ir? ¿Qué avances hubo esta semana?

M. No peleamos casi.

T. O sea que ese es un avance, ¿a qué obedece ese avance? 
M. Julián se portó bien. El viernes sí estuvo un poquito agresivo.

T. Claro, si Julián mejoró, la mamá mejoró y el papá mejoró porque todos están mejorando en la comunicación.

M. El jueves estuvo agresivo y el viernes quejas del colegio.

T. Si cambia Julián ustedes están mejorando y si cambian ustedes Julián está mejor, eso es como un círculo. ¿Qué pasó entre ustedes?

M. Pues no peleamos casi.

T. Él se rie $(P)$. ¿Qué quiere decir?

$P$. Es aleatorio, un día sí, otro no, este fin de semana, lo de siempre.

T. ¿Sintió mejoramiento como ella?

P. Un poco.

T. ¿Qué mejoró?

M. Que no lo grité.

T. ¿Y estos cambios en qué les ayudan a ustedes?

P. Sí, pero como yo le decía la vez pasada, hay veces que ya no le paro bolas, si bien, bien y si no, no. No soy de juego de peleas.

T. De alguna manera la pauta de comunicación entre ustedes en esta semana mejoró. ¿Y eso qué les invita a pensar?

M. Que podemos mejorar las otras semanas.

T. ¿Genera esperanza en ustedes?

M. Sí.

T. ¿Y a usted qué le indica?

P. Es un primer paso.

T. Felicitaciones por ese paso. ¿Habian dado ese paso alguna vez?

M. No.

T: ¿Qué les invitó a darlo internamente en ustedes?

M. Pues, porque como el niño estaba escuchando y esto es de adultos, yo no le puse cuidado, lo dejé allá con su amargura.

T: Por respeto al niño. O sea que Julián se puede volver en un aspecto ético para ustedes. ¿Y usted qué experimentó con el cambio de ella?

P. Pues tranquilidad.

T. Entonces usted también revivió su esperanza de que es posible el cambio. 
P. Sí, siempre he dicho que se puede, yo pienso que son momentos buenos y malos, que a veces son más continuas las peleas y eso es lo que nos está afectando. Pero no es que lo nuestro sea un infierno, son temporadas.

Puedo identificar cambios importantes en el sistema parental en la medida en que reportan generosidad en los aportes mutuos, la condición de respeto como valor fundamental en la relación con Julián y veo claramente el límite establecido entre el sistema parental y el filial; reconozco en sus tonos emocionales un estado de bienestar y de esperanza en el proceso de cambio, esto para mí es un indicador de ajuste y cambio en el sistema parental.

En virtud de mi experiencia en este tipo de casos, cuando veo cambios sustantivos basados en la lealtad de los padres, confío que se ha creado un contexto de protección saludable para el niño y puedo con más propiedad abordar la relación del niño con los padres. Puedo identificar también los recursos psicológicos de la pareja, especialmente sus sentimientos y su grado de vinculación como esposos y el compromiso de ambos en la construcción de una vida familiar próspera. Como terapeuta reconozco la capacidad resiliente de este sistema y experimento con más propiedad una visión esperanzadora del cambio.

Por lo demás, experimento una cercanía con la madre al sentirla mejor posicionada y emocionalmente más recuperada, y aunque es un tanto prematuro confirmar la consolidación de ciertos cambios, tengo la expectativa de que vamos en buena dirección en la consolidación del sistema parental. En este momento pongo el acento en la complementariedad de la pareja de padres para ayudar a los miembros a comprender como la pertenencia a este sistema se puede enriquecer y superar las limitaciones de cada miembro en el ajuste del sistema parental.

\section{Discrepancias en la relación de padres y la elaboración de pautas viables para resolver los conflictos}

M. Es como de personalidad, a veces me levanto de mal genio.

T. ¿Cuál es el sentido de su mal genio? 
M. Pues no sé.

T. ¿Eso se relaciona con su historia de vida que comentaba la vez pasada o con su situación actual?

M. Sí, de pronto, siempre soy así.

T. ¿Es así o se comporta asi?

M. Sí.

T. Uno no es así, uno se comporta así.

M. Lo que pasa es que como me dicen era igual que Julián, tenía ese movimiento acelerado, de pronto es eso, porque nunca me medicaron.

T. La medicación es para el sistema nervioso pero la manera mental como uno maneja la vida no necesita fármacos. Creo que está atascada acerca de la comprensión de las situaciones suyas y de su bijo.

M. ¿Será?

T. Usted cree que es biológica la situación y no psicológica.

M. Pues es que el psicólogo nos dijo que era algo biológico.

T. Eso le puede decir el psicólogo pero depende de uno como entienda su situación vital; porque el mal genio, su estructura y su modo de comportar no son hereditarios; uno puede cambiar su forma de percibir el mundo, pero eso depende de lo que uno decida. Llama mucho a la atención que usted lo defina biológicamente, porque como no hay fármaco, entonces se comporta de mal genio.

M. Ya no cambio jajaja.

T. ¿Por qué se sonríe usted?

M. Ya no hay fármaco, no cambio.

P. Ya se acostumbró Julián a eso y todos nosotros, y nos hemos acostumbrado a que es lo que ella dice.

M. No es eso, yo soy bien normal, pero él me quiere imponer las cosas en mi casa.

T. Entonces ahora empieza a encontrar una razón psicológica para ponerse mal.

M. Sí, él me impone las cosas.

T. ¿Entonces es el fármaco o la situación de la vida?

M. No sé, él me impone las cosas, siempre me pelea por eso. 
T. Si él le impone usted se incomoda, si él no le impusiera usted estaría mejor, y así usted está mejor, él también lo está. Pero si usted se incomoda él se incomoda.

M. Claro, nos incomodamos todos.

T. Entonces mire la danza que bailan ustedes, es una danza de incomodidad. ¿Les gusta esa danza?

M. Pues a él, le gusta sobresalir.

T. Entonces usted le responsabiliza a él de la situación y usted responsabiliza a ella de la situación. Observen la danza. ¿Desde cuándo viene así esta danza?

M. Éramos normales, pero luego de dos años a él le gustan las visitas en la casa, a mi no me gusta. Entonces un día me puse brava, fui grosera, pero uno no debe guardarse nada.

T. El modo de decir las cosas es importante.

M. Ese es el problema, que después de que tenga rabia, regaño, soy brusca.

T. ¿Y eso cómo ocurre?

M. Como me salga en el momento.

T. La manera como ustedes resuelven sus diferencias es muy importante.

P. Es lo de siempre, lo de la visita, yo no veo problema que cada mes mis hermanos vengan a la casa, es mi familia, casi nunca los veo.

M. No, ese no es el problema, el problema son las cuñadas.

P. Pero son parte de la familia.

M. Pero no es mi familia.

T. Veo que ustedes no llegan a acuerdos.

$P$. ¿Cuál es el tema de las familias? A uno le toca aceptar que ella invite y cuando yo digo invito a mi familia, le caen mal todos ¿cuál es el problema?

T. Esa ha sido una pauta desde el inicio de la unión.

P. No, pues mis hermanos se organizaron y yo quiero que nosotros los hermanos estemos cerca y ella no. No puedo decirles que vayan a comer porque ella no lo permite.

T. Volvemos a lo mismo, que los acuerdos no están establecidos. ¿Y quieren llegar a acuerdos o no? 
M. La verdad no.

T. ¿No qué?

M. Es que es mi casa y si yo quiero estar sola y él nunca está, y si me mantengo sola yo no tengo porque recibir...

P. Ese es el problema, ella sí se contradice, que es su casa, pero yo si debo aceptar, y cuando estoy llegan sus familiares.

M. Igual ellos casi ni entran, yo les dije que no volvieran.

T. O sea sus acuerdos no están establecidos. ¿Quieren establecerlos o no?

P. No, es que mi familia...

T. La pregunta no es si quieren que llegue la familia o no, porque ambos tienen derecho a pensar en su condición personal, el asunto es cómo quieren vivir los dos.

M. Sí de pronto quiero arreglar, pero...

T. Entonces siguen enfrentados, ustedes me dicen que eso no fue desde el comienzo. ¿Cómo era en el comienzo?

M. En el comienzo la mamá de él estaba viva y nos reuníamos allá, luego falleció.

T. Las reuniones se hacían allá en la familia de P. Como si él hubiera reemplazado el centro de la familia.

M. Sí. Y la personalidad de ella cambió, me miran mal a Julián.

T. Y usted se siente mal.

M. Yo les dije como Julián es así y ellos se incomodan, por eso no vuelvo y no las quiero ver acá. Luego después dice que yo mando en la casa.

T. Entraron en conflicto.

M. Yo le digo: es que usted se sienta en la sala y no se da cuenta que ellas empiezan a hacerle el feo a él, ¿entonces por qué tienen que llegar a mi casa si Julián los va a incomodar?

T. Reconozco su necesidad de búsqueda de acuerdos ¿̇por qué no los hacen?

M. Es que yo le digo. Sí hacen reunión, por qué no se va solo y él me dice que no porque lo dejo tirado.

T. Y como quieren arreglar esta situación entre ustedes, ambos tienen sus razones. 
M. Sí, porque antes no era así, pero me di cuenta de eso y él no quiere aceptar.

P. No, es que para mí no tiene sentido esa situación, ella tiene su familia, yo la mía.

M. Pero es que su familia no piensa en él.

T. Veo que ustedes no llegan a acuerdos.

P. No, es que para ella no puede ir nadie, ni yo a la casa de ellos, porque allá solo para qué.

T. Mejor dicho la familia se volvió problema para ustedes, Julián se volvió un problema, el tiempo de la vida familiar se volvió un problema. Todo se volvió un problema.

M. Sí.

T. Estoy de acuerdo, sus razones son sus razones. La pregunta es, el problema no es Julián, son los desacuerdos entre ustedes.

$P$. Es que ella no se da cuenta, que siempre es por el niño, no podemos estar detrás de él, nosotros lo estamos aislando.

M. No, porque como voy a mandar a mi hijo donde la profesora, solo está pendiente de dos, la profesora no me va a responder.

T. ¿Entonces qué van a hacer? El problema es la danza de los desacuerdos. ¿Qué hacen bailando esa danza?

P. Ya ni siquiera para entrar en peleas, y uno le dice y siempre el choque.

M. No sé, la verdad.

T. Tengo la impresión de que si no llegan a esos acuerdos Julián seguirá con dificultades, ustedes con mayor agresión, hasta llegar a una separación.

$P$. Y es que eso que dice usted ya se tocó hace rato, si esta relación no funciona pues hágale.

T. Lo que pretendo es llevarlos a considerar si se quieren organizar en pareja de nuevo, para lo cual necesito saber si están dispuestos a aportar y no sé. ¿De qué depende que estén dispuestos?

P. Que ella cambie.

T. Pero es que el cambio no comienza con ella, es de iniciar los dos porque o si no, ustedes condicionan el cambio. Hoy tiene más sentido el sintoma de Julián, porque él que vive en medio de 
ustedes, ¿para dónde mira? Hoy considero más a Julián, porque ambos con sus razones no han estructurado una unión, entonces la pregunta es qué hacen en pareja.

M. No sé.

P. Cuando decidimos juntarnos nunca bubo acuerdos.

T. Mejor dicho se montaron en el barco y adelante.

M. Una familia somos nosotros, no puedo tener la de él ni la mía, por eso le dije a mi mamá que se fuera.

T. Me parece sensata su decisión.

$M$. Es que yo quiero vivir sola, y no le veo problema a querer vivir sola.

T. Es una buena idea, si es su estilo y lo informa, ahora su esposo dirá si quiere compartir ese estilo o no.

P. Pues es nuestra familia, los niños y nosotros, pero eventualmente tampoco nos podemos separar de quienes nos rodean.

T. Estoy de acuerdo, dice que tienen que vivir en su significado de familia intima y no se pueden aislar. ¿Ahora, cómo esos dos puntos de vista se ponen de acuerdo?

M. Ahí voy yo. Hace cinco meses nos invitaron a un cumpleaños, llegué de buen genio, luego me le hicieron un desplante al niño. Yo dije no vuelvo, le estaba haciendo caso a él de ir, integrarnos y ella sale con eso. Le dije: la próxima va usted solo porque si va a una piñata y lo sacan a un lado...

P. Ese día rompió un poco de cosas.

M. Si y reconocí. Dije que no más familia.

T. Tengo la impresión de que ustedes se desprotegen como pareja. ¿Qué pasaría si ustedes se protegen como familia?

P. Lo que veo es que quiere que yo esté detrás de todo el mundo.

T. Miren sus argumentos, ustedes no se protegen como familia. ¿Qué tanto están dispuestos a protegerse?

M. Ese es un punto, igual yo no voy a aceptar que me impongan la familia.

T. Está en el derecho de aceptarlo, el asunto es que si no los acepta y no hay acuerdos, no hay protección. Ese punto es muy importante para sus vidas que puedan concertar en su diferencia, no se trata de imponer un estilo $u$ otro sino crear algo diferente a sus 
estilos personales y eso tiene que tener un sentido de protección. Tengo la impresión de que seguramente tienen sentimientos importantes para con el otro, pero no han aprendido a hacer transacciones y renuncias para caminar en pareja.

P. Las cosas buenas y malas, para tomar decisiones y lo tengo claro, pero es que...

T. Otra vez tú dices "yo intento pero ella no se deja", y tú dices "yo he hecho ajustes y tampoco me ayuda", están en la no cooperación.

M. De pronto puedo hacer el acuerdo. Pero yo le digo: él va con uno y ni se da cuenta, igual es su familia; yo le he dicho. Si quiere váyase solo.

T. Eso es un problema de acuerdos. Argumentos hay, el problema puede ser el que sea si están dispuestos a abordar cosas, pero no lo sé.

M. Desde que no se metan conmigo.

T. Usted dice si no se meten conmigo y él también, y se amenazan.

P. Estamos centrándonos en la familia, pero es en todo sentido, no tenemos vida social, hay eventos en la empresa y no asisto porque no lo permitió.

T. La pregunta es ¿por qué están ustedes en esta relación?

M. Yo le dije a él que nos separamos, yo nunca he tenido esposo y me queda complicado que me digan qué hacer.

T. Bueno, por su estilo personal porque quizá no está dispuesta, eso es más honrado, me parece honrada.

P. Y yo le dije lo mismo, si siente que no tiene sentido.

T. Claro y ella lo está diciendo y usted también lo dice de corazón.

T. Es su estilo personal y si no lo quiere cambiar es su acto de libertad. Si quisiera apostarle a esta pareja tienen que renunciar a muchas cosas señora, pero si no quieren renunciar a muchas para ganar otras, pues es mejor como su honradez se lo dice. Lo que no puede es entrar en una contradicción.

P. No sé.

T. Por ejemplo querer imponer su familia en esta familia. Llamémoslo así, por decirlo de alguna manera, o no desligarse de su familia para estar en esta. Cuando uno se casa, se organiza en su casa. 
P. Sí, pero no me debo olvidar de que tengo hermanos.

T. Yo no me olvidé de que tengo hermanos, pero mis hermanos no pueden pisar mi casa sin invitarlos.

P. No digo que deban estar en mi casa, pero me gusta verlos. Y si vamos donde ellos y el joven hizo un daño, yo no lo puedo ocultar.

T. Pero en ese momento debe proteger a su mujer e "bijo".

P. Sí, pero.

T. Daré un ejemplo más claro, porque no quiero entrar en contradicción, iré con algo más personal. Mi esposa es de esas familias muy amalgamadas y eso es respetable, mi familia es más bien independiente. Recién casados ella decía este fin de semana tal cosa, yo le dije déjame yo me quedo en casa, y llegamos a un acuerdo, yo voy cuando quiera y ella sigue muy vinculada con su familia y eso no nos pone en discusión, es el acto de libertad.

P. Exactamente es que eso es lo que yo digo.

T. Se da cuenta, ella le dice, vaya con la familia y disfruta.

P. Eso lo dice acá, pero allá...

T. Bueno, pues usted se va con su familia. La pregunta es ¿usted por qué está aquí?

P. Lo primero por el comportamiento del joven, lo segundo me di cuenta que no es solo de él sino la familia, y lo tercero, sé que tengo que hacer cambios en mi forma de actuar.

T. Es como cuando hay una danza, yo la invito a, pero usted está de lado, le digo cuádrese mejor o si no, no bailamos bien. Es una acomodación de ambos pero ¿̇i están dispuestos a bailar la danza de la pareja? No sé si estén dispuestos, al menos su esposa dice que no está dispuesta, ¿usted qué dice?

P. No la puedo obligar, si ella dice que ya no, mal haría en obligarla, yo acataré y haré lo necesario si no, no.

T. Me parece sensato. Es como invitarla y ella no quiere bailar. No quiere bailar y asi se hagan cosas pues no se puede bailar, es sensato decirle muchas gracias señora por ser sensata y decirme la verdad y no por pararse y bailar de mala gana, porque yo me siento mal. ¿Es asi?

P. Sí. 
T. Para que forzarla si por la mitad del baile le hace mala cara y le empieza a reclamar. Ella no quería bailar y usted le insistió, en vez de haberle dicho, bueno señora, cuando quiera bailemos la pieza, porque usted no puede forzar porque entra en una contradicción. ¿Qué sienten ahora?

M. Que vamos de mal en peor.

T. O de mejor en mejor, porque es con honradez del corazón, peor sería que se mintieran y eso sería peligroso para Julián, para sus vidas o para un tercero. Entre más sean honrados van mejor. Para mi va mejor. ¿Qué piensa usted? Abora uno quisiera que funcionara, pero se necesita disposición, pero si yo no quiero y no es mi estilo y tal, ¿qué siente señor?

P. Pues no es nada del otro mundo, si estoy con alguien que no quiere estar, no funciona y me parece muy sensato si realmente no se quiere estar con esa persona, eso me parece chévere y no puedo obligar.

T. No se puede obligar, la pareja es una danza y no se puede obligar a que el otro esté.

P. Sí, es como si donde estoy trabajando y no me siento a gusto.

T. Es un acto de libertad, si no hay libertad, no hay consideración para el otro y uno no está obligado a amar ni a sus hijos, ni a su mamá, ni a su esposo... uno no está obligado, es algo a lo que uno está dispuesto.

M. Sí ese es un punto, porque hay varios. Él también se fue a trabajar en campo, llega cada 15 días y jummm.

T. Ahora la entiendo mejor, es un esposo parcial. ¿Y qué otro punto hay de reserva?

M. Se va a viajar y llega a mandar.

T. Sí, se siente descalificada y desencantada. Ahora entiendo porque no está dispuesta, son sus puntos de vista.

P. A mí el tema del trabajo, pueda que tenga razón en que no está continuo en la relación, yo sé que no es fácil, pero yo le digo si es el trabajo para un crecimiento profesional.

T. Estoy de acuerdo, no es la familia, ni Julián, ni el trabajo, son los acuerdos entre ustedes. Hace rato están un poquito distantes en la relación. 
P. Ese es el punto.

T. Es el sentimiento de los dos que está quebrado, ese amor, sentimiento y solidaridad se fracturó, hubo algo que la fracturó, porque veo a su señora desencantada y necesitada y usted exigiendo.

P. Claro. En lo del trabajo era para dos años, lo petrolero es variante.

T. Vea a su señora. Lo necesita y usted se va; entonces entiendo a la señora, después lo entiendo a usted, pero entiendo las dos películas. Ella dice se va, llega cada quince días y usted dice: pero estoy solo y los necesito, todos amalgamados. Ella necesita su privacidad, entonces usted no lee las necesidades de ella ni ella las suyas; se olvidaron de leer las necesidades del otro, ambos se desencantaron. Entonces saben que hay que hacer un pare en el camino, el barco llega a un puerto, hay con qué para seguir el viaje o nos quedamos, pero, o bien separados o bien unidos, pero no mal separados o mal unidos. Deben hacer un balance de la situación y mirar nuevamente sus acuerdos. ¿Por qué asienten con las cabezas?

M. Sí, toca o si no...

P. Sí.

T. Sabian que estaban bailando las danzas de los desacuerdos queriendo acordar entre los desacuerdos. Están en el puerto y necesitan una reingeniería, o va bien o no. Ambos están de acuerdo. ¿Les parece? Todo eso gracias a Julián.

P. Es la raíz, porque somos nosotros y hay muchas situaciones.

T. Lógico, porque sus expectativas mutuas empezaron a cambiar, y cuando hay negocio en la vida y no se cumplen las expectativas pues hay que cerrar el negocio.

P. Eso es lo que pienso, que la vida no es cuadriculada, el tema es cómo las afronto. Cuando empezamos la relación era un ambiente y una situación, todo era diferente, todo cambio, no fuimos capaces en su momento, no lo dijimos, seguimos, cambiamos los modos de pensar y reventó.

T. Porque las parejas tienen estadios de crecimiento, no es una estructura plana, tienen fases y requieren acuerdos, ¿̇eran conscientes de este proceso? 
P. Que habia que cambiar.

T. ¿Qué es lo nuevo que han logrado en este proceso?

$P$. El hacérselo saber sin agresión.

T. Necesitaban un mediador, yo estoy circunstancialmente.

$P$. Es que yo digo: no siempre necesitamos de otro.

T. Claro cada uno quería imponer acondicionando los cambios y eso no es bien, por eso necesitaban venir acá, pero como no encontraban un asistente usaban a Julián.

P. Era la excusa.

M. Siempre le pagábamos psicólogo a Julián y P nunca venía.

T. Bueno, pero abora está aquí.

M. Sí pero porque lo invitamos.

T. Sí, era su deber moral invitarlo.

M. Era la hora.

T. ¿Qué piensa de lo que concluimos?

M. Pienso que siempre tengo la razón y la voy a tener.

T. En algunas cosas, en otras no.

M. Nooo, siempre la tengo.

T. Usted tiene la razón en su parte y usted en la suya, tiene la razón en cuanto es legítima su posición y él la tiene porque quiere que se hagan cambios

M. Muy poca digo yo. Él es mentiroso, me dijo primero que viajaba tres meses, vamos dos años y llega y dice que un cambio pero qué...

T. Estamos de acuerdo en sus inconsistencias, pero acá no vinimos a ver quién tiene más la razón, ambos están en el conflicto.

P. Ella siempre es la que no...

T. Seguimos en el juego, no quiero mas eso, de verdad me podría cansar de su juego, y no quiero eso, ustedes ya están cansados de acusarse. El punto está en que hemos llegado a la conclusión de hacer un balance de la pareja para reorganizarse, se quedan o se van. Pero podrían decir no queremos el balance y nos vamos, es mi sugerencia, ¿qué quieren?

$P$. Es ver conscientemente lo que quiere cada uno.

T. Es para mirar sus recursos y poder ver si se quedan o no. 
P. Realmente lo que dice es claro, ¿qué es lo que queremos?, ¿̇uál es la sintonía? Y no ponernos a acusarnos. Sí no hay un cambio real, que no siga más esto.

T. ¿Qué historia quieren escribir desde ahora?

P. Una familia donde yo pueda estar, donde esté si estoy con ellos, sentir una familia, un hogar, que a la distancia uno esté al tanto.

T. Pero para escribir esa historia necesita que la otra persona también esté de acuerdo.

P. Claro, es lo que yo digo y no puedo obligar y al final es esto y ya, hagamos algo. Llevo dos años en lo mismo, estoy cansado, soy adulto centrado, quiero mi organización.

T. ¿Quiere definir la situación?

P. Exacto y hay otra persona.

T. Es su hija.

P. Es una sobrina que ha pasado por una situación difícil.

T. Y usted qué historia quiere escribir.

M. No sé.

T. Está en libertad de pensarlo. Sugiero por ahora una cita individual con cada uno de ustedes para evaluar su aspecto más personal y luego sí hacer otra cita de pareja para mirar qué quieren definitivamente, porque de esta decisión depende mucho Julián.

M. Sí, a veces le echamos la culpa de lo que no es.

T. Así es, él paga las consecuencias de lo que ustedes no han arreglado en sus desacuerdos. Le sugeriría no hablar del tema hasta que vuelvan a la sesión de pareja. Por hoy sería hasta aquí.

Se revela en esta sesión la pauta complementaria de desacuerdos, discrepancias y pautas impositivas de la pareja, se reafirma la triangulación de Julián en el contexto de la relación parental y los límites en el sistema conyugal. Ante la lucha por imponer sus historias personales, sus mitos y creencias, provoco de manera intencional ahondar en las discrepancias y los confronto ante la realidad, toda vez que necesitamos tocar el trasfondo del vínculo parental y de su vínculo afectivo y emocional como pareja, lo cual nos permite ver las dificultades emocionales de la pareja que poco a poco en la sesión se fueron 
resolviendo. De esta manera empecé a sentir acople emocional de sus vínculos como padres.

Mi vivencia era la de poder comprender que hay sentimientos fuertes que los unen, pero que paradójicamente sus discrepancias y sus estilos de vida no han podido ser superados por una clara configuración del estilo nuevo de pareja. La emergencia de sus subjetividades hizo que como personas en absoluta libertad eligieran su destino; reconozco en cada uno de ellos su sinceridad y el valor para enfrentar la crisis por la que pasa el sistema de pareja. Siento la necesidad de ahondar individualmente en cada una de las posiciones y sugiero una sesión individual para abordar la postura más personal en la situación. Acudo a mi experiencia profesional y sé que en estos casos una consulta privada con cada miembro de la pareja permite evaluar con propiedad la disposición y los estados emocionales con los que están abordando la situación y su proyecto de vida personal, para luego re configurarlo en pareja.

\section{Tercera sesión}

\section{Contexto general}

En virtud de la estrategia generada y para profundizar en sus posturas personales en cada uno de los miembros del sistema, se divide en dos partes, la primera parte aborda a la madre de Julián y en la segunda a su padrastro. El propósito es evaluar a profundidad los elementos subjetivos de cada uno y posibilitar las coordinaciones de sentido intersubjetivas necesarias para consolidar el sistema parental.

\section{Primera parte: sesión con la madre}

\section{Recomposición vivencial emocional de la madre con su historia y restitución del vínculo con Julián. Vinculación emocional con el terapeuta y expresión de sentimientos}

T. Hoy vamos a tratar sus aspectos más personales de manera confidencial, de igual manera lo haremos con su pareja. Esta es una 
posibilidad para entender mejor la posición de cada uno de ustedes ante la situación familiar.

M. Bueno.

T. ¿Qué reflexiones le ha suscitado la sesión anterior?

M. A Julián de pronto le hace falta esa presencia paterna que no tiene con su papá porque él no lo quiere, Julián no lo quiere, y de pronto con $P$ formó un cariño diferente, le dice papá a P; cuando yo me uní con él estaba pequeño.

T. He observado una relación buena entre Julián y su compañero.

M. Sí, él lo quiere mucho, para él es su papá.

T. Esa es una buena relación que hay que preservar y por eso es importante garantizar una buena relación entre ustedes como padres. Por lo tanto es necesario reconocer un tanto su posición personal. Quiero conocer cómo es su vida.

M. Como le comenté tengo tres hijos de mi primer compañero, lo que pasa es que usted no sabe, pero me ocurrió algo muy duro y eso está afectando a Julián; el tercer niño, F, me lo robaron.

T. ¿Cómo fue este acontecimiento?

M. Un día salimos con Julián a la tienda, eso fueron unos minutos nada más, yo vivía con él sola porque mi hijo mayor está con los abuelos y cuando nos devolvimos, el niño ya no estaba. Esto fue muy duro, casi me vuelvo loca, acudí a todos los medios posibles de las autoridades pero no me dijeron nada. Entonces Julián sintió mucha rabia, cosa que todavía tiene y yo para calmarlo, le dije que se lo habían llevado los del ICBF (ella llora).

T. Comprendo su situación, muy difícil por cierto.

M. Este fue un golpe muy duro que me hizo pensar en mis otros dos hijos y en mi vida, porque me sentía perdida, este asunto no se me borra de mi mente. Yo estudio, yo trabajo, yo sigo, pero dentro de mí digo no, que tal que un día vuelva ¿̇ierto? (Habla con voz entrecortada y llora).

T. Entonces la pérdida de su hijo la llevó a reflexionar, a aprender.

M. Sí.

T. Y aún está aprendiendo... 
M. Es que la vida se trata de eso... continuar (se entrecorta la voz y queda en silencio).

T. Así es.

M. Porque igual... yo digo que con todo lo que he vivido, todavía me falta mucho por vivir.

T. Uno nunca termina de aprender.

M. Cada día surge algo nuevo, y yo digo, imagínese con todo lo que he visto y he tenido que pasar, todavía me falta.

T. Entonces esta experiencia se relaciona con el modo como se relaciona con Julián.

M. Sí claro.

T. En qué sentido.

M. O sea por ejemplo ahoritica, que los paseos y todo. De pronto yo lo sobreprotejo porque como le digo, no puedo estar pendiente de él. O sea desde hace tiempo no le doy un abrazo, no soy una mujer cariñosa, muy raro ¿sí? Pero igual estoy pendiente que nadie me lo toque, que nadie se meta con él, con sus cosas, no lo dejo salir, no lo dejo ir a paseos. En el colegio siempre vivo recomendando que no me lo dejen salir solo, que ojo con los extraños, que si lo tocan... Igual duré con él tres años que no lo llevaba a ningún lado, me tocó contratar a una señora particular, porque él no quería irse para el jardín, porque como él vio todo.

T. Entonces de alguna manera la pérdida del hijo incidió para que tomara decisiones de protección con Julián. Una manera de recuperarse por la pérdida de su hijo, el cual usted piensa que no protegió.

M. Sí, sí.

T. ¿Entonces lo protege demasiado?

M. Sí, se me fue la mano con Julián porque pues, sí, lo tuve demasiado encerrado también.

T. Por el miedo que tenía de que pasara lo mismo con el hijo que perdió.

M. Ya no lo dejaba salir, estaba muy encima de él, era muy grosera.

T. Es como una paradoja; de un lado supone que el hijo que perdió 
fue por descuido y entonces sobreprotege a un Julián para no descuidarlo.

M. Sí, sí, igual con mi otro hijo yo voy y lo visito y estoy pendiente.

T. Osciló en los dos extremos.

M. Sí, por eso le digo, es que...

T. Y qué pasaría si no oscilara entre los extremos, pensar que a un bijo descuidó y al otro cuidarlo demasiado.

M. Pero yo lo he intentado, por eso le digo mis crisis ya no son tantas como antes; hay momentos en que vuelven, pero yo con ellos soy normal, hay dias en que no quisiera levantarme en mi hogar, es normal. Igual yo no salgo de mi hogar, me voy a estudiar y de ahi a mi casa.

T. ¿De qué dependen estas crisis?

M. Dependen de lo que sueñe.

T. Puede darme un ejemplo.

$M$. A veces que sueño mal, hay dias que no lo recuerdo, como que cada vez que lo recuerdo me pongo muy mal y a veces me levanto y sueño con él, digamos ¿sí? Me levanto ese día insoportable ino! Ese día no me aguanto a nadie. Lo peor ino!, grosera, yo voy por la calle y me tocan y yo ino!, me encierro. Me encierro, a veces duro días sin comer, no me da hambre.

T. Y qué pasaría si cuando lo recordara tomara más coraje para seguir haciendo su vida más digna por él.

M. Sí, es que eso es lo que trato de hacer, a veces me digo no voy a llorar, no voy a llorar, no voy a llorar, me voy a poner bien ¿si?

T. Claro.

M. Pero si en un mes determinado lo recuerdo entonces ya no puedo ¿sí? O sea estoy mal, yo no sé, me pongo como histérica no sé, luego el tiempo pasa y ya me siento bien, no sé. Es difícil, es dificil.

T. Así es, no es fácil.

M. No... no... porque llevo seis años (llora), me pone asi es... o sea si yo supiera que está bien o si supiera que está así, como la niña que adoptamos, yo la encontré tirada por allá en el sur, entonces 
yo le dije a P que yo la quería porque se parecía a él. Me puso problema y todo al principio, pero él aceptó, yo la tengo en la casa, pero no es lo mismo.

T. ¿O sea que usted adoptó una hija en nombre de su hijo perdido? M. Sí (llora).

T. Y decidió amar a Julián y protegerlo en pro de la memoria de su hijo.

M. Sí.

T. Eso alivia un poco su dolor.

M. No, no, porque los tengo abi en un caparazón y no los dejo ser ellos, ellos a veces me dicen "mamá déjeme salir porque me tiene aqui encerrado".

T. ¿Qué podría hacer o qué ha pensado hacer para que la memoria de su hijo sea cada vez más una fortaleza y no una debilidad?

M. No sé, pues él me da fortaleza y yo trato, pero igual yo digo que yo lloro como cualquier mamá, pero igual yo ya no soy tan débil, me hubiera visto cuatro años atrás.

T. ¿Qué la ha hecho tan fuerte?

M. No, yo siempre fui una mujer fuerte.

T. Sí, puedo darme cuenta de ello.

M. Lo que me dolió fue perderlo tan bobamente, diría yo, estaba bien económicamente, tenía todo y si hubiera llegado diez minutos antes, yo la mato, hasta de pronto estaría en una cárcel ¿no? Haberlo perdido tan bobamente, en mi propia casa, me lo robaron, en mi apartamento, no haber llegado antes, o sea es como que yo digo, por qué me quedé escampando y no llegué, porque Julián estaba molestando y me quedé porque estaba lloviendo, eran los vendavales del 2007. Estaban cayendo unas granizadas aqui en Bogotá y en una de esas granizadas perdí a mi hijo.

T. Después que estas cosas suceden, uno se pregunta qué hubiera hecho para que no pasaran, pero no podemos anticipar lo que sucede en la vida, son sucesos inesperados.

M. Sí, yo a veces pienso que fue castigo de Dios, yo era muy arrogante, yo peleaba y era incontrolable, la cogía contra todo el mundo. 
T. ¿Qué pensaría si el acontecimiento fuera tomado como una bendición y no como un castigo?

M. (Silencio).

T. Porque es una prueba de la vida y depende uno como la asimile.

M. Sí, yo soy consciente que es una prueba... pero es duro. Yo sé que voy a salir adelante, pero es que la verdad yo no hablo de este tema con mi familia, la verdad.

T. Gracias por su confianza.

M. No, yo de pronto nunca, desde la pérdida de mi hijo hasta hoy, yo de pronto no estaría hablando con usted, porque de pronto ha pasado mucho tiempo y de pronto ya necesitaba hablar con alguien sobre esto.

T. Volviendo al significado de la experiencia, si usted lo toma como un castigo se sigue culpando, pero si lo toma como una bendición podría tener sentido el hecho de adoptar a su hija, tener sentido la decisión de proteger a Julián y en sintesis formar un hogar.

M. Sí, a veces me pregunto ¿por qué la encontré a ella? Yo a veces digo, yo la encontré a ella así tirada, asi mal, se estaba muriendo, estaba prácticamente con cáncer, nadie la quería, todo el mundo la dejó tiradita. Yo la recogí, pasé días y noches en el hospital porque ella vomitaba cuarenta veces al día y la gente me decía “Ay usted por qué es tan boba, dejó de estudiar por ir a criar”. Y yo les decía "no sean metidos, qué les importa, yo veré qué hago de mi vida, cállense”. Les cerraba la puerta, muy guache, yo soy muy guache cuando quiero serlo, no soy hipócrita pero soy muy guache. Pero si yo vi en ella, de pronto por recuperar los años que yo no vi crecer a mi hijo porque es que con Julián tuvo una infancia muy rara porque Julián caminó como rapidísimo, gateaba muy poco, a los diez meses hacía de todo.

T. Eso se relaciona con que sea un niño muy inteligente.

M. Sí, lo que uno tiene que hacer con Julián es hacer cosas, por ejemplo mañana tiene clase de inglés, él ha sido muy rápido para todo ¿sí? Y después de las dificultades solo eran quejas y quejas, y luego pasó lo de su hermano, que a él también lo afectó, me decía que 
quería matar a alguien, él me hablaba de muerte y muerte al que se robó al bebé.

T. Tanto usted como su hijo tomaron la pérdida de F como un reto; este desafío puede ser de venganza o de lucha positiva.

M. Él vivía solo para poder matar al que se robó al bebé y yo ahora hablo con él y es como hablar con un hombre.

T. O sea la pérdida de su hijo lo bizo crecer tanto a usted como a su bijo.

M. Sí, porque él dejó de actuar como un bebé, a pesar de sus ocho años, él habla como si fuera un hombre grande.

T. Entonces la pérdida de su hijo trajo también bendiciones.

M. No, para mí no fue una bendición, fue más bien una prueba de vida para que uno pueda...

T. Para ver lo que no habia visto.

M. Para ver lo que no habia visto, sí.

T. Fue una dura prueba pero necesaria.

M. Sí, de pronto si fue necesaria.

T. Quisiera saber ¿cómo siente esta conversación?

M. No, pues me libera, me libera porque igual lo que yo le digo, yo no hablo de este tema con nadie, ni con $P$. El a veces me pregunta "pero dígame que tiene", no, prefiero irme a la calle, con mi mamá tampoco, ni con mis hermanos, con nadie mejor dicho. En mi casa está probibido hablar de mi hijo y el que venga a hablar de mi hijo, lo echo. Está prohibido. Pero sí, después de esto su recuerdo es mi fortaleza.

T. Y la fortaleza de Julián.

M. Sí porque yo le digo Julián, y él me dice "mami es que yo voy a estudiar y lo voy encontrar algún día" y con la niña ha cambiado bastante porque él no tenía esa compañía, se la pasaba solo y ahora con la niña ya puede convivir y no es tan agresivo, y si va a maltratarla uno le dice y él dice "si perdóneme, discúlpeme".

T. ¿Entonces en nombre de su hijo perdido, usted encuentra una oportunidad con sus dos hijos ahora para ser mejor mamá?

M. Sí, porque he encontrado esa oportunidad, yo a ella la quiero mucho. 
T. Quiero felicitarla porque ha tomado las cosas en la dirección correcta porque en nombre de su hijo ha validado su vida, su rol de mujer, y ha constituido un hogar. Esto es una prueba de su fortaleza.

M. Es lo que me mantiene fuerte.

T. Bueno hasta acá hemos conversado un aspecto muy importante de su historia personal.

M. Ah bueno, le agradezco.

T. A usted por su confianza; lo que es claro es que esto va a ser muy útil para la vida con Julián, porque si usted comprende su historia, las relaciones con Julián mejorarán.

M. Sí, porque igual a veces digo: de pronto yo le he trasmitido eso a él. T. ¿En qué sentido?

M. En que siempre que estoy mal, el único que siempre está es él, entonces él me dice "mamá no llore" y llora también. Ahora no, que si me dan ganas de llorar pues bueno me voy para un parque y no delante de él para no alterarlo. Se ponía así con mucha rabia y me decía yo voy a encontrarlo, y no quiero que mi hijo crezca con esos resentimientos con tanto odio y cometa una desgracia o algo, porque usted sabe que cuando uno crece con rabia nadie se lo va a quitar. Por ejemplo yo, con mi padre no tengo relación, estos días me llamó y me dio duro, yo pensaba después de 15 años viene a llamarme y con una vida muy triste, de alcohólico y borracho.

T. Lo importante es que usted está reivindicando toda esa historia.

M. Sí, pero con lo que uno crece en su cabeza o con lo que crece de su infancia, es muy complicado devolverlo, yo no quiero que mi Julián viva eso.

T. Es toda una suma de motivaciones. Fíjese que usted se organizó con su esposo, adoptó la niña, quiso formalizar una familia y organizarse con Julián y amarlo como mamá, todo esto fue a partir de una situación dolorosa, muy dolorosa. La vida depende de cómo uno utiliza sus fuerzas en el momento de la crisis.

M. Sí claro, yo sé que es duro y yo sé que lo voy a superar, igual yo siempre lloro porque digo es mi hijo y donde esté, yo siempre lo voy a llorar pero igual yo me he hecho muy fuerte, porque yo digo 
mi hijo va a ser grande, yo veo a Julián como un doctor, un ingeniero; todo el mundo me dice que va a ser un delincuente, no...

T. Sí, él es muy pilo y con esfuerzo lograrían los objetivos que se proponen.

M. Sí, la profe de tecnología le recomienda teatro.

T. Muy bien por todos estos propósitos. En este sentido quisiera saber ¿̇ómo siente este proceso que hemos instaurado con su familia, su hijo, su esposo y con usted?

M. Lo lleva a uno a cuestionarse, lo que pasa es que la verdad ya no creía en los psicólogos, porque yo pagaba psicólogos particulares y hacian un reporte y ya... me lo enviaban a la casa, de pronto al hablar con una persona, en que se me... o de pronto a mí, debe inspirarle a uno confianza, porque la vida privada de uno no se la comparte a todo el mundo...

T. Gracias de nuevo por su confianza.

M. La mayoría de psicólogos solo entran, recogen, y de pronto no he tenido la oportunidad de dialogar, o de pronto no le dan confianza a uno, y uno va a lo que va, y chao.

T. ¿No tenía confianza en ellos?

M. No, a mí me decían pero si estudió cinco años en la universidad... y yo les decía pero si a mí no me inspira confianza entonces no puedo; igual que con Julián si él me decía que no lo llevaba a otro lado, en cuanto a qué estudió, pues para mí qué estudió no tiene nada que ver, pudo haber estudiado lo que quiso, pero si a mí no me inspira confianza no hay nada. Uno se puede echar a la pena y tirarse de un puente o seguir adelante y esperar que pase la vida, falta todavía.

T. En la medida en que se comprenda todo esto, la vida con Julián será mejor, y también los recuerdos se volverán positivos, en la medida en que uno instaura también una bondad en la vida a partir del hijo que perdió; porque lo interesante de estos procesos es como uno reelabora la vida, la cambia, la transforma. Es decir que este proceso le ayuda precisamente a esperar ese momento $y$ ¿qué más cree usted que le aporta este proceso psicológico a diferencia de las otras ayudas psicológicas anteriores? 
M. Que es más personal, no es una consulta médica y que ya y chao. De pronto acá tenemos más conexión para tener más confianza. Le digo que hace seis años que fui al psicólogo y ya me hacía falta.

T. Entonces vamos por buen camino.

M. Sí, vamos por buen camino, igual creo que yo soy capaz de resolver todo esto.

T. Sí usted es muy fuerte, veo su coraje y ahora veo por qué Julián es así, que también es inteligente para entender los procesos y determinar con responsabilidad sus actos.

M. Sí, hay veces que soy grosera con él y me paso, pero a veces soy firme y no doy mi brazo a torcer, y a P a veces no le gusta y abi es cuando yo le digo: pues váyase.

Se observa claramente que al abrir el espacio de conversación individual surge una historia no revelada hasta el momento que le da sentido a todo el marco general con Julián y entiendo con mayor claridad la situación emocional de la madre, ante lo cual establezco progresivamente la relación con la historia familiar actual. Para ello utilizo el relato como dispositivo humano que permite la organización semiótica de la vida y utilizo el acto narrativo como medida para configurar y reconfigurar las percepciones, significados y sentidos del mundo vivido en esta situación concreta de la experiencia, de la pérdida de un hijo. Sin embargo como todo dominio narrativo y contextual es un espacio relacional de configuración de las relaciones con el terapeuta, con sus hijos, incluyendo el ausente.

Esto le da un marco más ecológico al self de la madre, de tal manera que el proceso psicológico emerge y se reorganiza de nuevo al utilizar la vida subjetiva de ella, encarnada en la experiencia de su self en las interacciones con sus hijos y con el self de otros significativos en su vida. Como en muchos otros casos, hago una relación entre historia narrada e historia vivida y esta distinción permite que los acontecimientos recordados por la madre tengan sentido en el escenario de la conversación con el terapeuta; comparto con ella el significado de 
esta experiencia dolorosa de la pérdida de su hijo como una experiencia para aprender de la vida. La historia me conmueve y en tal sentido comprendo más emocionalmente a la madre en su drama y a partir de este momento genero una clara intención de connotar positivamente su experiencia. Creo en el proceso resiliente de los sistemas humanos y opto en este caso por continuar la intervención en esta dirección, reconociendo los recursos y fortalezas de la madre.

Puedo observar ahora que el proceso ha activado un proceso resiliente en la madre y esto genera en mí un mayor acercamiento interaccional con ella; además reconozco sus potencialidades en medio de tanto drama vivido. La re significación de su historia me invita a pensar que ella está mejor posicionada emocionalmente para manejar la relación con Julián y con su compañero y esto permite una posibilidad de redefinir los vínculos de la madre con todas las personas significativas para ella. Recuerdo en este pasaje la relación permanente entre los órdenes narrativos y vinculares que debo tener presentes, incluyéndome en el contexto de la relación con ella como facilitador de su proceso.

Los pasajes vividos reviven en mí las vivencias de otros procesos de ayuda, también en situaciones similares de dolor, y ahora estoy más confiado en las posibilidades de una reconstrucción de la historia y de los modos de vinculación del sistema consultante. No dudo en observar las resonancias de la historia vivida por la madre y la mía y cómo las experiencias personales del terapeuta resonaron también en la vivencia del proceso terapéutico de la madre; esto fue evidente en la apertura de la madre y en cómo a cada intento que yo hacía para cerrar fases del proceso de la conversación, ella animaba mucho más la búsqueda de comprensión de su historia en nuestra relación terapéutica.

Observo en la madre no solamente una mayor disposición al proceso, sino que lo comprendo mejor, así como la apropiación de sus propios cambios. Lo que más se puede destacar es la reconstrucción de una nueva visión acerca de la historia presente y del porvenir de la madre con sus hijos, lo cual está relacionado con su estado emocional más sereno y despejado. Esto antecede a la posibilidad de seguir avanzando en la consolidación del sistema parental. 


\section{Identificación de los cambios en la relación conyugal y evaluación de la postura emocional de ella como miembro de la pareja}

T. Otro punto que tenemos que hablar es cómo ha sentido la relación con su esposo.

M. No, yo a él lo quiero mucho para qué.

T. Porque lo que yo vi es que hay contradicciones y si se ponen de acuerdo, se resuelven. Porque si no es así, el proceso va hacia las discusiones y las escaladas de maltrato.

M. Yo le dije que día eso, el problema es de aceptarnos, si no me acepta y yo no lo acepto entonces no vamos a llegar a ningún lado; de resto no vamos a tener ningún problema, porque lo que le digo él: no es un hombre violento, es más bien noble, a mi se me ha pegado algo de eso.

T. Sí, porque ese juego de quién domina a quién es peligroso.

M. No, pero yo voy a hacerle caso. Eso desde que yo le sirva el desayuno, no peleamos (risas). Yo siempre analizo y digo como que me pasé y él es muy noble.

T. Como usted dice, analiza las consecuencias en la relación.

M. Sí, analizo.

T. Es importante mirar cada uno de esos aspectos porque son definitivos para la formación de Julián, Porque en la medida que ustedes dos estén de acuerdo, Julián va a estar mejor.

M. Sí, es que Julián lo quiere mucho, como si fuera su papá; y a $P$ yo siempre le digo que bueno pero que de abí no se pase, que no le vaya a pegar a mi hijo. Cuando está muy pasado entonces le digo que no sea así.

T. ¿Y esto lo dice delante de Julián?

M. Antes sí lo hacía delante de él, ya no, yo lo llamo y hablamos; es que él lo pone estilo militar, pero no es toma trago ni así, nada de eso. Porque desde que hicimos el acuerdo...

T. ¿Ha funcionado?

M. Sí, ha funcionado.

T. Reconozco los logros. De otro lado, ¿qué fue lo que más le impactó de la conversación de hoy? 
M. El recuerdo, sí.

T. ¿Qué idea nueva se lleva?

M. No, idea no. Yo siempre he estado clara de lo que quiero y para dónde voy. Lo que pasa es que me siento más liberada.

T. ¿Y algo surgió de la conversación?

M. Mmm pues sí, creo que la pérdida de mi hijo no fue tan negativa, porque de pronto uno no sabe lo que tiene hasta que lo pierde. Sí, además porque Dios, el universo, en lo que usted crea, le pone las cosas a decidir al destino.

T. ¿Será el destino?

M. Pues la vida, uno no la puede controlar toda ¿no?

T. Entonces hay fuerzas que son superiores a las del ser humano, que confluyen para bien o para mal. Le ponen a uno referentes para definir a uno la situación. Yo creo que asi uno aprende de los momentos difíciles.

M. Sí, abi vamos.

T. Ahi vamos. Es un proceso.

M. Ahi voy, no me he dejado caer tampoco, para mi familia siempre soy como la que está ahi dando fuerza, mi mamá si necesita algo pues yo apoyo, yo le doy.

T. Usted tiene una tendencia que me parece interesante y es ser protectora.

M. Sí, yo con mi hermano lo apoyo.

T. Lo importante es cómo saberlo hacer.

M. Cuando estuvo mi hermano en la casa como unos dos tres meses, yo le dije a mi hermano: "bueno vaya produzca porque usted tiene treinta años, yo no lo voy a tener aqui haciendo nada, usted ya tiene treinta años”. Mi mamá me preguntó: “¿y usted por qué me lo sacó?”. Yo les doy, pero cuando tengo que exigirles soy dura.

T. Estas fortalezas son muy importantes en este proceso. Ahora daremos paso a su esposo.

El sentido de esta parte final de la conversación con la madre tiene el propósito de evaluar la postura de ella como miembro de la pareja y rastrear los cambios obtenidos por la sesión anterior donde se trabajó 
el sistema parental; al respecto es muy importante para mí establecer los límites entre el sistema conyugal y el sistema parental, toda vez que la claridad en sus límites nos permite situar el foco de intervención y resolver al interior del sistema los dilemas necesarios para evitar le interferencia entre los subsistemas. Esta premisa como la han destacado los clásicos terapeutas de familia y pareja, entre ellos Minuchin, permite comprender más la naturaleza del síntoma ubicada en el hijo. Como era mi intuición, el vínculo conyugal está soportado por fuertes sentimientos de afecto y admiración de ella por su compañero y deja ver también la capacidad de ella para establecer vínculos emocionales estrechos, lo cual es un recurso muy importante que seguiré animando.

\section{Segunda parte: Sesión con el padrastro}

\section{Exploración de la historia personal del padrastro y procesos subjetivos de sus diferentes roles en el sistema familiar}

T. Estábamos hablando con su esposa, sobre usted y sobre su hijo.

P. (Sonrie).

T. ¿Cómo va Julián?

P. Está un poquito más calmado.

T. Usted sabe que esta conversación tiene el carácter de confidencialidad y el propósito es para avanzar con los procesos más personales. Al respecto, ¿cómo le ha ido en la relación con su familia $y$ con su esposa?

P. A veces hay altibajos ¿no? Momentos buenos, momentos malos, situaciones, pero no es la mejor ni la peor situación, entonces a veces hay momentos de pelea, de disgustos, de hacer cosas en familia, el problema es el temperamento tanto de ella como el mío entonces ahi empiezan los problemas pero no es algo como tan anormal. La cosa es cómo manejar los temperamentos y y a estaríamos mejor.

T. Y ¿ cuáles son los momentos más tensionantes?

P. ¿Momentos tensionantes? No, pues cuando se le lleva la contraria a ella: "que es así, que no es así, que hagamos esto, que así no".

T. Y ¿qué hace en ese momento? 
P. Ah pues me empiezo a alterar y luego me callo, para no seguirle la pelea, y yo espero que se le baje un poco la calentura, no tengo la costumbre de imponerme en la pelea porque no tiene sentido, paso a no tocar el tema y...

T. Actúa como de una forma muy estratégica.

P. Sí, para no andar ahi como en esa pelea, porque usted sabe que se puede agrandar por andar con la cabeza caliente.

T. Muy inteligente en cierta medida. ¿Cómo le ha ido en su matrimonio? ¿Cuánto llevan?

$P$. Ya viviendo...casi cuatro años.

T. Si se hiciera una evaluación del grado de satisfacción de esta relación ¿cuál sería?

P. De un cien por ciento de satisfacción, un ochenta, un setenta por ciento. Como le digo hay momentos buenos, momentos malos. Pero siento que han sido cuatro años de lucha nuestra porque sacar adelante a dos jóvenes.

T. Esto es un buen balance.

P. Sí, pues nada, ahi trabajando durísimo y sacándolos adelante; dándole de sol a sol. Pero sí ha servido la ayuda, sobre todo en lo grosero, creo que vemos un avance, se han logrado cosas.

T. O sea que para usted el avance es bueno.

P. Sí, a pesar que estos últimos días que ha sido un poco complicado pero entendiendo también los problemas de la distancia, la distancia no es fácil para ellos.

T. Ella se queja un poco de eso.

P. Sí, el tema del trabajo, cuando nosotros empezamos a salir yo tenía mi trabajo en Bogotá en oficina, pero nosotros trabajamos en el sector petrolero que es muy dinámico y los tres años fue un periodo muy bueno para la empresa, pero las condiciones exigían trabajo de campo, pagan muy bueno, habia muchas expectativas pero lo complicado es que toca estar yendo de aquí a allá. Se arrancó bien pero ha sido difícil para ella y los cuatro años conviviendo, y los tres hemos estado...

T. Juntos.

P. Juntos y no juntos (ríe). 
T. Sí, estoy entendiendo.

P. Yo sé que no es fácil para ella y para nosotros, porque todos los compañeros estamos en la misma situación, las peleas pues al principio las escuchaban mis compañeros y pues me decían que bueno que entendiera la situación y ahora la estoy viendo, entiendo que es un poco la distancia, pero es algo que no quiero darle vueltas para no generar más estrés y de no seguirle la cuerda en las peleas porque sé que no es fácil, por eso estos dias que quedan nos toca aprovechar. Ella no ve que también para mi es un sacrificio porque uno anda alejado de todo mundo y a uno le toca duro, pero para pensar en un futuro hay que hacerlo.

T. Le va bien.

P. Sí, para qué, me ha ayudado ser muy juicioso y centradito.

T. Bien, eso como familia y como pareja ¿cómo le ha ido con ella?

P. Bien, pues yo ya le conozco sus chocheras, sus cosas, que es impulsiva, pero entonces, creo que la conozco y reconozco las necesidades que tiene, lo que pasa es que hay que ver como se dicen las cosas. Pero en general...

T. Les ha ido bien.

P. Sí, señor.

T. Y como padres ¿cómo van?

P. Ah bien (sonrie). Con los dos pelaos, es el tema del joven, el comportamiento ahi vamos. Yo siempre he dicho que es cuestión de normas, no de estarle dando rejo, ni nada de eso, solo es que haga cosas, que asuma, que haga su oficio, es decir que arregle su habitación, que si comió lave su loza, que entienda que no somos empleados de él, ni de nadie.

T. Comprendo su punto de vista.

P. Cosas básicas, el uniforme del colegio, cosas básicas.

T. Y ¿cómo se acompaña con la madre?

P. Cuando ella está en la misma sintonía y ella se cansa de la situación de él, llego a decirle a Julián que le haga caso.

T. Y se puede decir que ¿el problema es de él?

P. Sí, el problema, es el problema del estudio, de una u otra forma lo llaman a uno a decir que "mire que el niño no está haciendo 
caso", le digo "flaca, mire no tiene que llegar a tratarlo así, que cumpla con las normas básicas".

T. Estoy de acuerdo con su sugerencia para con ella.

P. Entonces como que a ella no le gusta, él no hace caso y ella se calienta, a veces se rompe la...

T. Se rompe la armonía, el acuerdo.

P. Sí.

T. ¿Por qué se rompe el acuerdo?

P. Nada, porque para ella siempre se debe solucionar desde el punto de vista de ella.

T. Entonces veo dos posturas extremas. Usted siempre quiere una educación estricta y ella lo sobreprotege.

P. Exacto, claro yo digo que es lo básico, tampoco es que llegue al extremo que tiene que ser todo así, eso es lo básico, que se mantenga en la línea, que se salga un poquito bueno, pero cuando se sale mucho y ella no me deja corregirlo, entonces le digo "flaca ¿cuál es la vaina?”, porque yo le digo que siga la norma y ella me dice que no haga eso.

T. Lo importante es llegar a acuerdos, porque si los establecen les va a ir mucho mejor, él es un niño muy inteligente; la estrecha relación que tiene con Julián genera un rol con usted, esa es la impresión que tengo ¿̇si?

P. Con él no es fácil.

T. Pero a usted... lo veo con mucho recurso para ejercer su rol de "padre".

P. Sí, pero ni emocional ni económicamente es fácil, eso es así.

T. ¿Entonces, por qué lo hace usted?

P. De pronto por el cariño y el aprecio que le tenía a ella ¿no?, cuando uno toma la decisión es con el paquete completo.

T. Estaba enamorado.

P. Sí, exacto, sí. Entonces para mí no fue fácil porque mi familia es muy cómo decirle a usted... ¿chapada a la antigua? Entonces esa situación no encaja para nada, hablábamos de ciertos familiares que tomaban esas decisiones y decíamos "como fue a hacer eso" "Ojalá a ustedes no les pase eso". Entonces nada, fue de corazón 
que salió y al principio si fue difícil, por la formación que uno tenía... como muy tradicional.

T. Un cambio fuerte.

P. Sífue fuerte, pero no siento que haya sido para mal, no he sentido rechazo hacia ellos, mejor dicho hacia nosotros.

T. Sacaron adelante su familia.

P. Sí (risas).

T. Lo sacó adelante.

P. Sí, el cambio se le nota porque antes de los tres años era más difícil, pero a medida que pasaba el tiempo se estableció como una especie de respeto.

T. Además Julián es muy inteligente para captar cosas, si se siente bien con la persona, como fue conmigo en la entrevista, él inmediatamente se acomoda, es muy recursivo.

P. Exacto, y ya con la niña... que la adoptamos, esa fue otra situación que no fue fácil.

T. ¿Cómo fue con ella?

P. Ella es hija de una hermanastra mía pero por apellido, bueno eso es una situación abí... el caso es que esta niña estaba sola, desamparada y enferma.

T. Entonces en general el balance es bueno.

P. Sí.

T. Y cómo siente este proceso de ayuda.

P. Bien, nos está ayudando a todos.

T. Bueno, serán invitados a una próxima sesión.

P. Para la próxima estoy fuera de la ciudad por cuestión de trabajo.

T. Bueno, entonces será para la madre y Julián.

El chequeo de la postura personal con el compañero de la madre me deja varias impresiones. Primero, en la medida que voy sondeando la historia personal de él y su relación con la esposa veo que se han ido acoplando en el tiempo y que el destino de esta familia es relativamente promisorio porque hay recursos emocionales de la pareja; han tomado decisiones de desafío en la historia de la familia y están dispuestos a permanecer unidos. Segundo, el efecto de la primera sesión con el 
sistema parental y el análisis de los disensos y búsquedas de consensos les ha dejado clara la importancia de la coordinación de sentidos para acoplarse como padres y en el chequeo que hacen de estos efectos, lo validan como bueno, especialmente en el manejo con Julián; Tercero, tengo la sensación de que se ha resuelto un impase temporal de crisis en la pareja y que el posicionamiento de los miembros de este sistema es más flexible y prometedor; al respecto creo que los sentimientos auténticamente expresados por los miembros de la pareja en la exposición de su self individual y con toda libertad han garantizado un orden de afianzamiento de la misma; de igual manera los vínculos entre sus miembros se ven cada vez más claros y con prospectivas generativas de protección y de solidaridad entre los miembros de la familia.

Observo la postura de la madre y del padrastro mucho más adecuada en relación a la protección y al manejo de la situación con Julián. También identifico una postura más sólida de P como miembro de la pareja y como padrastro de Julián. Ante todos estos sucesos, creo necesario una cuarta sesión con la madre y el hijo para avanzar con la madre en la reconstrucción de su historia, ahora en presencia del hijo, el cual la ha compartido. Esta sesión permitirá ajustar los vínculos de la madre y el hijo y recomponer la historia dramática vivida.

Sigo reafirmando la hipótesis de que a mayor afianzamiento de la configuración del sistema parental, la liberación del síntoma en esta familia será posible a partir de que el contexto de interacción es más propicio para la vida de Julián.

\section{Cuarta sesión}

Asisten la madre y Julián.

\section{Restitución de la historia del hermano perdido como ritual de cambio en la vida de las relaciones del niño y de la madre para la reconstrucción del vínculo}

T. Bienvenidos. ¿Cómo va el proceso Julián?

\section{N. Bien.}

T. ¿Qué quiere decir bien?... ¿mejorando?, ¿y en qué ha ido mejorando? 
N. Con mi comportamiento.

T. Descríbame algo de lo que haya mejorado...

N. (En silencio).

T. Bueno, la mamá nos puede contar... ¿qué dice al respecto?

M. Pues estos días no ha estado tan, tan... en el colegio la semana pasada, estuvimos toda la semana en coordinación porque le pega a los compañeros.

T. ¿Y en qué ha mejorado entonces?

M. Pues asi mejorado... no.

T. Un poquito o algo desde las citas, ¿̇como qué?

M. Pues en estos días me ha hecho más caso cuando sale a la calle, pues ya voy y lo busco y se entra... porque le gusta la calle mucho... me toca ir y buscarlo... pero del comportamiento con los compañeros no ha mejorado.

T. ¿Julián qué dice de esto?... ¿y qué pasa con los compañeros?... ¿te ofenden?...

N. Me ofenden.

T. ¿Qué te dicen por ejemplo?

N. Me tratan mal a mí o tratan mal a mi mamá.

T. ¿Lo tratan mal a usted o a su mamá?

N. A mi y a mi mamá

T. ¿Y qué dicen de su mamá?

N. Qué es fea.

T. $Y$ ¿de verdad es fea?

N. No.

T. ¡No! ¿Es simpática... entonces?... es por molestar... porque sus amigos no saben cómo es su mamá, ¿sí o no?

N. Sí, y malas palabras.

T. ¿Y contesta las malas palabras?

N. No.

T. ¿Entonces qué hace?

N. Le digo a la profesora.

T. ¿Le dice a la profesora y ella para la discusión?

N. A veces. 
T. La vez pasada estuvimos trabajando en una historia, que creo que tú sabes, la pérdida del hermano... ella me contaba que también le dolió, ¿̇recuerda algún momento especial de esta historia?

N. Sí, señor.

T. ¿Cómo cuál?

N. Que se llevó el bienestar a mi hermano.

T. ¿Cómo fue esa experiencia?, ¿qué ocurrió?

N. Que fue muy triste.

T. ¿Aún estás triste?

N. Sí.

T. ¿Lo recuerdas todos los días o a veces?

N. Desde hace un tiempo a veces lo recuerdo y a veces no.

T. Ya... con su mamá llegamos a un acuerdo para recordar bien a su hermano, ¿podría la mamá comentarle?

M. Hablamos con el doctor de no volver a pelear por eso... ¿sí? Y de recordarlo de la mejor forma posible.

T. Teniendo un recuerdo bonito para la vida y en nombre del hermano hacer las cosas para bien suyo. Entonces pueden hacerle una promesa a su hermano. ¿Cómo se llamaba su hermano?

N. F.

T. Entonces la promesa podría ser algo así: " $F$ en nombre suyo, quiero comportarme de la mejor manera y hacer lo posible para vivir la vida mejor”. ¿Qué le parece esta promesa para F?

N. Bien.

T. ¿Recuerda la imagen de F?... ¿cuantos años tenía cuando eso sucedió?

N. No me acuerdo bien.

T. La Mamá nos puede ayudar.

M. Un año.

T. ¿Qué le parece esta promesa que hicimos junto con la mamá? ¿Le parece bien?

N. Sí, señor.

T. ¿Por qué?

N....(Silencio).

T. ¿Le preguntamos a la Ma por qué? 
N. Sí.

T. ¿Por qué es buena la consigna, Ma?

M. Pues porque asi no vamos a estar peleando, ni me voy a levantar de mal genio ni voy a estar discutiendo con ustedes y contigo por su comportamiento.

T. ¿Qué piensas Julián... de esta promesa para F?

N. Que está bien.

T. Podrían prometer recordar espiritualmente a F y ponerlo como testigo del mejoramiento de su relación.

Se reportan cambios de comportamiento en el niño y durante el proceso de verificación él evoca el incidente con relación a su hermano, a lo cual me hago sensible en razón a conectar la historia del niño con la historia de la madre ya que fue revelada en la sesión anterior; establezco la historia como contexto histórico de la vida de Julián y lo relaciono con su estado emocional.

Al evocar la historia se ve claramente el sentido de la experiencia de la desaparición del hermano tanto para la madre como para Julián y encuentro una conexión auténtica de los relatos, lo cual me invita a profundizar en ellos y a redefinir la historia de dolor presente en el niño y que corrobora el sentido dado por la madre a dicha experiencia. Tengo presente que la conversación es un espacio relacional de constitución, mantenimiento y negociación de las relaciones entre el self de la madre y el del niño y concibo esta conversación que es sostenida por los autores presentes y ausentes que se influencian mutuamente en el diseño de las nuevas relaciones. Por tanto la voz del niño ausente es reconocida en las posibilidades de transformación de las personas y sus relaciones; mi papel entonces ahora es de participar en la coautoría del nuevo relato y por ello sugiero una posibilidad de establecer un ritual con la evocación del hijo menor y hermano de Julián para consolidar simbólicamente el vínculo de la madre y Julián.

Experimento la sensación de que todo va encajando: el relato de la madre con el relato del niño y comprendo mucho más ecológicamente el síntoma. También puedo observar la descalificación del self del niño en sus contextos escolares, históricos y en el manejo cotidiano que le 
dan a su comportamiento. Utilizo con el niño similar estrategia a la utilizada con la madre en la redefinición de la historia y evoco para ambos la metáfora de hacer del hijo perdido un símbolo de desafío para el cambio y el sentido futuro de sus vidas. La respuesta por parte de ellos y en este caso específicamente del niño me invita a reconocer los recursos de él en tanto la fuerza de su carácter para enfrentar las vicisitudes de la vida y la potencialidad protectora de la madre que ayuda a mejorar la forma de vinculación con su hijo; busco con precisión la consolidación de un vínculo madre-hijo que sea protector para preservar el sistema; en este sentido utilizo simbólicamente la presencia del niño perdido como elemento estratégico para la conjugación de la intersubjetividad entre los self de la madre y el niño.

\section{La búsqueda de construcción simbólica del cambio en la pauta de crianza de la madre y la prescripción al niño. Usar su inteligencia como estrategia alternativa al síntoma}

T. Hablando ahora del colegio, ¿cómo le fue esta semana?

M. Pues el problema de él no es... o sea él es normal, lo que tiene es que es muy agresivo.

T. El comportamiento agresivo es una manera como el ser humano se protege, en ocasiones un modo de defenderse.

M. La profe dice que lo que tiene que mejorar es la parte de agresividad, lo cual es normal porque igual es un niño inteligente, él participa, él no es de los que se queda callado, no le da pena nada, es muy práctico, mire todos los pantalones rotos.

T. Muy práctico.

M. Sí muy práctico y así, no le importa nada.

T. Es muy sencillo en su comportamiento.

M. Normal, a mí me dicen que lo único es la agresividad, que si mejorara la agresividad sería el número uno del colegio, entonces por eso ellos no lo quieren sacar y como de todos los colegios lo sacan, entonces ellos han sido el único colegio donde lo han tenido para finalizar el año.

T. Porque valoran de Julián su inteligencia. 
M. ¡Sí!, valoran que es muy inteligente, muy rápido para las tareas, el primero que termina y todo, sino que termina y de una vez va a molestar a los demás.

T. Podemos pensar que una de las razones de la incomodidad de Julián está relacionada con la experiencia de la pérdida del hermano.

M. Sí.

T. Los dos, madre e hijo se comportan agresivamente por revivir ese asunto. La mamá estaba con ira, ¿lo sabias Julián?... tenía mucho dolor, much a rabia, mucha incomodidad y usted, Julián ¿también?... ¿quería destrozar el mundo?... ¿Por esas cosas quería pegarles a otros? ¿Qué es lo que más recuerdas de F?

N. Que era muy juguetón.

T. ¿Qué más recuerdas de F?

N. ... No me acuerdo

T. ¿La mamá qué recuerda de F?

M. Él tenía la tranquilidad que no tiene Julián, más tranquilo, no se movía tanto, era muy juicioso.

N. (Va al baño)

M. No le gustó la conversación.

T. Seguro es muy doloroso para él.

M. Sí de pronto él está muy inquieto, él está diagnosticado con el TDAH.

T. Sí, más allá del rótulo, eso es un estado emocional.

M. Yo no sé eso qué tiene que ver, o sea no entiendo sus movimientos, ¿si lo vio?, en el comedor, donde esté, siempre está moviéndose mucho.

T. Porque está ansioso; cuando uno está ansioso se mueve más de lo normal. Hay que encontrar las razones de por qué está ansioso, quizás porque hay presión en el medio, porque la mamá lo rega$\tilde{n} a$, porque lo amenazan; hay muchas cosas, lo recuerdo porque estuve revisando las sesiones pasadas. Lo que más me impresiona es que si se comporta normal la gente lo ve mal y si se comporta agresivo la gente le reclama, es como una tenaza que aprieta de ambos lados y él no sabe cómo comportarse, entonces es lógico que esté agitado. 
M. Ya... pero eso es normal en él o eso...

T. Es normal que se comporte así en esas condiciones, pero si se cambian, pues cambia su comportamiento. No sé si lo había entendido antes.

M. ¡Ś́!, que nosotros también participamos.

T. Sí, ustedes participan del modo que interactúan con él.

M. En el comportamiento de él... pero igual en la casa tiene la actividad de salir, pero él en el colegio se pone terrible cuando está con muchos niños, ahi es donde empieza a golpear.

T. ¿Cuando está con muchos niños?

M. Sí, ahi es cuando golpea.

T. Es importante estudiar eso, porque es la manera como se está adaptando al mundo y uno aprende a adaptarse al mundo llevando buenas relaciones y él tiene que aprender a llevar buenas relaciones, pero es parte de su aprendizaje, lo que tiene que aprender en la vida como todos.

M. Una amiga mía me habia recomendado aislarlo de los niños

T. Justamente lo contrario; porque si lo aislamos, él puede suponer que es un niño tan raro que lo aíslan.

M. Pues ella lo que me dijo fue que en el momento en el que él se desesperara y que iba a golpear a alguien, pues que ella me llamaba y que yo estuviera ahí, seguro para llevarlo a la casa.

T. Fíese qué idea tienen de él, como si fuera un animalito que si se despierta entonces no saben qué hacer con él; justamente esa imagen niega la personalidad de Julián.

M. Entonces me estaban hablando de aislarlo, de solo tenerlo en coordinación, de solo llevarle un juguito y lo tendrían abi haciendo tareas.

T. ¿Y a usted cómo le parece esa manera de pensar del colegio?

M. Pues yo ya he peleado con ellos y cuando peleo con ellos pues ya escriben una carta y me lo sacan.

T. Entonces la situación es como un triángulo, escuela-familia-Julián.

M. Sí, ya me lo sacan, entonces ya pierde los dos años o tres años.

T. Entonces lo que usted debe hacer es establecer acuerdos con el colegio. 
M. ¡Sí!, yo ahorita con ellos he tratado de llegar a acuerdos, me dicen que un tiempo, pero a él le hacen falta los niños, igual yo creo que él no se va a aguantar porque él es muy ansioso.

T. Él tiene su derecho al colegio como todos los demás niños.

$N$. (Entra sin chaqueta y la cuelga en la silla y camina por la sala).

M. Pues no sé si será eso lo que lo afecta totalmente o si será otra cosa.

T. Muchas cosas a la vez. Porque de un tiempo para acá ha sido de tensiones. Tensiones en los colegios con los niños, tensiones con la familia, tensiones en todos los lugares que Julián está; él no tiene una vida tranquila y tenemos que proporcionarle un contexto con exigencias, con reconocimientos pero sin tensiones, para que siga su vida normal; porque ¿en qué lugar se comportaba bien normalmente?

M. En el apartamento se comporta normal.

T. Entiendo, porque no hay presión.

M. Lo único es que le da ansiedad de salirse...

T. Siéntate Julián.

N. Tengo mareo.

T. ¿Tiene qué?

M. Tiene mareo.

N. (Sale nuevamente).

T. No quiere conversar, evade la conversación, pero fijese que la conversación que más evade es la de él.

M. Sí, ¿no?... y asi es en el colegio y sale y no hay poder humano que lo suba y hable con él, no contesta y lo cogen así como en varias personas y se queda callado y no habla y no habla.

T. Se bloquea, entonces todo ese sistema de presión es el que no le conviene a Julián... ¿usted cómo mejoró la situación en su vida personal que me dijo que era muy parecida a la de Julián?

M. Pues yo me crié en un ambiente, prácticamente en una finca y entonces uno se sale y se distrae con los animales mientras que en la ciudad uno vive en un apartamento prácticamente encerrado.

T. Encerrado sí; entonces el ambiente en el colegio es cerrado y encerrado en el apartamento también.

M. En el apartamento no tiene esa libertad de irse a jugar. 
T. Me recuerda un cuento hindú muy interesante: "habia un rey que tenía unos caballos muy finos, pero esos caballos estaban en el monte y eran briosos y muy mal educados, entonces el rey puso un aviso que al que le educara los caballos les daría premios; entonces vinieron los mejores domadores del reino y no pudieron amansarlos, pasaron hasta diez de ellos y ninguno pudo amansarlos; el rey ya decepcionado ofreció la mitad de su reino si alguno lo lograba, así que llegó un campesino y le dijo al rey que quería amansar los caballos y el rey accedió con desconfianza porque pensaba que el campesino solo quería su mitad del reino. El campesino le dijo al rey: "renuncio a su premio y permitame educar a sus caballos"; el rey accedió y al cabo de tres meses llegó el campesino montando un caballo con los otros detrás en fila de uno en uno; el rey asombrado le preguntó ¿cómo lo hizo? Y el campesino le contesto: "yo solté los caballos a correr en la llanura hasta que explotaron toda su energía y luego los amansé"...

M. (Sonríe).

T. ¿Por qué se sonríe?

M. Porque es cierto. Yo creo que es falta de soltar todo lo que uno tiene y sí, quizás yo sí tuve la oportunidad por lo que le digo, en la finca yo jugaba hasta la media noche y ya llegaba a dormir, mientras que él no. Entonces yo hablaba con P de irme a vivir a tierra caliente en un apartamento más amplio con aire, que él pudiera como divertirse, ¿sí?

T. Bonita idea.

M. Sí, no estar como tan encerrado, porque ahi no le sirve como por su...

T. Su energía; tiene demasiada energía y no la ha canalizado.

M. Sí, lo mandé para el campo pero igual...

T. Sí, pero tiene que tener la guía como el domador de los caballos, la guía de la madre y del padre.

M. No, yo no lo dejo ir solo, a los 8 días me lo devolvieron, acabó con el gallinero, con el burro, con la vaca.

T. Porque no tenía la guía que lo educara. 
M. La tía me dijo "yo lo dejé hasta donde él quisiera", pero quedó sorprendida ante la energía de él, no se cansaba.

T. ¿Qué pasaría si canalizáramos la energía de él?

M. De pronto sí, él mejora, igual estamos con deporte.

T. Me parece apropiado.

M. Sí claro, igual hay veces en que me la vuela pero igual yo soy consciente que soy la madre y sé que yo soy la que voy a estar abí apoyándolo, ¿no?

T. El modo como usted lo ve es clave porque si usted hace lo mismo que hacen los demás de descalificarlo y controlado, como en el ejemplo, el potro se vuelve brioso, más se altera; en cambio, si se puede educar si se le libera con orientación.

M. Sí, igual es mejor atajar que arriar, yo siempre lo be dicho.

T. Es una buena metáfora.

M. Sí, a mí me gusta que en determinado momento yo le digo, bueno Julián hasta acá y es hasta acá y ya.

T. Y él comprende y accede.

M. Y para, tiene que parar... pero ya decirle todo el día "pare"... sería fastidioso.

T. Sí entiendo bien, entonces usted no quiere repetir su historia con Julián.

M. Sí, yo creo que sí... ve tan raro que es la vida porque tengo tres hijos y ellos no son así, el único es él.

T. Los temperamentos son diferentes, ellos son calmados.

M. Sí, más calmados, ellos se parecen más al papá, igualiticos al papá y Julián no. Igual el papá se llevó al otro hijo y no se llevó a Julián. Igual Julián no quería.

T. ¿Y a usted que le pareció esa decisión de Julián no haberse alejado de usted?

M. Yo veo que el niño es de carácter y dice que no y me quedo con mi mamá así me cueste. Y del otro niño si me molestó que de pronto se fuera del lado mí y no, él se fue, y él está allá y él está contento y viene y me saluda y ya.

T. Así fue la historia.

M. ¡Sí!, mi madre me lo recuerda todos los días: ¡mírese! 
T. Es como si fuera una réplica suya.

M. Pero mejorada.

T. Si usted mejora la relación con Julián no se repetiría la historia. En esta tarea puede ayudar P, que se la lleva bien con Julián.

M. Además que es impresionante, él solo escucha un ruido o ve que se para y de una vez es Julián y él sí, señor, ya quedó abí, no le dio ansiedad, no le dio nada, ahi quedó.

T. Quizás sabe manejar la energía de Julián.

M. De cierta manera sí, lo que pasa es que él lo ve como esa figura paternal.

T. Con mucho respeto.

M. El respeto que Julián le tiene a él es impresionante.

T. Ese respeto se gana por el vínculo cercano que tiene. Así como lo quiere, le pone limites.

M. Sí, debe ser porque Julián es muy inteligente y las coge muy rápido, entonces el otro día me decía... me hizo una pregunta y yo ni sabía qué responderle, me dijo: "Mamá apenas mi papá me vio dijo a ese ¿Julián no lo quiero? ¿Así se lo dijo?” Y yo dije: “¿cómo?” "¿O sea mi papá apenas yo nací me vio dijo a este niño yo no lo quiero?..." Y yo le dije: "no papi él no lo vio, él no volvió..." y él me preguntaba con insistencia y yo cómo le digo, y él me dijo: "pues la verdad, si algún día se aparece yo no lo quiero, ni que se aparezca en la puerta porque él nunca me ha dado nada".

T. Por lo tanto él tiene la sensación de haber sido "rechazado".

M. Sí.

T. Entonces Julián se agita cuando la gente lo rechaza. Hay que cambiar la historia de rechazos y P está cambiando esa historia, de una historia mala del padre a una historia buena.

M. Sí, y él mismo me dice: "mami yo quiero que P sea mi papá", él mismo lo dice.

N. (Entra).

T. Me estaban contando algo muy interesante.

N. Yo escuche al otro lado.

T. ¿Escuchaste del otro lado (de la cámara)? ¿Y qué escuchaste? (el terapenta sabía que estaba al otro lado de la cámara) 
N. De que mi mamá dijo que cuando yo le pregunté de lo de mi papá no supo qué responderme.

T. Pero usted hizo una cosa muy inteligente, reemplazo a su padre por $P$, ¿es así?

N. Sí, señor.

T. ¿Y se sientes feliz con eso?

N.Sí.

T. Muy inteligente. Estábamos hablando que es muy inteligente, resolvió algo de una manera muy interesante.

M. Y él solo, porque se le pudo haber dicho u obligarlo... No, él solo.

T. Estábamos diciendo que usted tiene una energía muy fuerte, una energía interna muy fuerte y que si retiene su energía entonces explota tremendamente, en cambio, si dejamos que la energía se canalice, que corra y que se utilice en el deporte y en muchas otras actividades, usted estaría más tranquilo.

N. Si, señor.

T. ¿Por qué dice "sí, señor"?

N. Porque me gusta el deporte.

T. ¿Y cuál deporte le gusta más?

N. Fútbol, basquetbol... ese.

M. Natación.

N. Sí, natación.

T. Es una de las actividades que más recomendaría porque no solo integra el cuerpo y la mente, además regula el funcionamiento del cerebro.

M. Sí, donde lo teníamos lo sacaron.

T. Hay que buscar que lo practique en otro lado.

M. Estamos buscando otra piscina. Mire que él es muy fuerte y lo pusieron con un poco de niños más pequeños y se los llevaba por delante.

T. Requiere entonces una piscina más grande.

M. Sí.

T. Esa es una tarea que hay que hacer.

M. Sí, claro. 
T. Ella promete que va a canalizar mejor su energía, también después su mamá le va a contar una historia de un rey y unos caballos. ¿Escuchaste el cuento?

N. No.

T. Mamá se lo va a contar más luego.

N. Alcancé a escuchar de cuando estaban hablando... no sé de qué.

M. Bueno va a mejorar su comportamiento ¿sí o no?... Explíquenos acá por qué golpea a sus compañeros, al menos una sola razón.

N. Porque a mi hermano se lo llevaron al bienestar familiar.

T. ¿Y qué pasó?

N. Es que no sé porque se llevaron a mi hermano si no hizo nada.

T. ¿Lo llevaron al bienestar? ¿Quién se lo llevó?

N. No sé, porque nosotros salimos y cuando volvimos las puertas estaban abiertas y no estaba.

T. Y se lo llevaron al bienestar y todavía está en el bienestar...

N. No sé si aún está ahí o si ya se lo llevaron.

M. ...Pues obvio uno se lo cuenta de esa forma como para no ser tan duro o brusca... pero así es, así como se le contó así pasaron las cosas.

T. Entonces cuando recuerdas eso ¿qué sientes, te incomoda?... Bueno eso ya pasó, así que no le tienes que cobrar a otro chico lo que pasó... Por eso la historia de F hoy empieza a ser positiva en ustedes. ¿La quieren tomar positiva? Pueden hacer una promesa, ¿sabe lo que es una promesa? ¿Qué es una promesa?

$N$. Una promesa es cumplir lo que dice.

T. ¿Y qué promesa le haría a F?

N. Que me voy a comportar bien.

T. ¿Qué más le prometería?

N. Que... que... ¿qué era?

T. Que canalizaría toda su energía para hacer las cosas bien en nombre de F. ...¿¿Sabe qué es canalizar? Utilizar bien la energía en nombre de $F$.

N. Eeeeee... Se me olvida.

M. Utilizaría bien la fuerza.

N. F utilizaré bien la fuerza en el nombre del amor que te tengo. 
T. ¿Qué sientes con esta promesa que has hecho?

N. Feliz.

T. Bueno, la mamá ¿qué siente con esa promesa?

M. Pues ojalá que sea verdad y la cumpla, porque las promesas se cumplen.

N. Como tú que no me las cumples, el otro día no me llevó al parque, me promete que me deja salir y no.

T. Esa promesa suya Julián es un compromiso en nombre de F. ¿Qué promesa le haría a su bijo?

M. Que me voy a comportar mejor, voy a tratar de dejar de fumar, de ayudarlo, de estar abi pendiente, de cualquier consejo que necesite para bien.

T. Igualmente de canalizar bien la energía de Julián.

M. Sí, canalizar bien la energía de mi hijo que es como bastante...

T. Fuerte, eres un niño fuerte, ¿sí o no?... ¿̇asi te sientes?... ¿Como un niño fuerte?... ¿Con mucha energía?

N. Si, señor.

T. ¿Y qué hacen los que tienen fuerza y energía?

N. Se ponen a estudiar mucho.

T. Por ejemplo se ponen a estudiar.

N. Y a aprender muchas cosas.

T. Bueno, va a hacer todas esas cosas... ¿cómo se siente la mamá en esta conversación?

M. Pues bien porque por lo menos está hablando, porque él no habla, uno le pregunta algo y se queda callado totalmente.

T. ¿Usted qué cree que yo estoy haciendo aqui para que él hable?

M. No sé.

T. ¿Por qué habla Julián conmigo?... porque intento comprender a Julián... no le incumpla a Julián las promesas y entienda la fuerza de Julián... como el campesino que amansó los caballos.

M. Sí.

T. Entendió la fuerza de los caballos... ¿qué piensa?

M. Que sí es eso, que de pronto no me comunico bien, porque igual yo le pregunto y no...

T. De pronto es la manera de preguntarlo. 
M. Sí.

T. Entonces hay que aprender a comunicarse con Julián. Cada hijo tiene una forma de comunicación distinta, yo también soy padre $y$ he vivido esas necesidades.

M. Sí claro, total.

T. Cada uno es diferente.

M. Sí, todos somos diferentes.

T. (Choca el puño de él con Julián en términos de saludo)... Entonces con cada uno toca aplicar códigos de comunicación distintos.

M. Sí, eso fue algo que no me explicaron.

T. Sí, eso no lo explican a los padres. No hay cartillas, lo aprende uno con la experiencia. La siento mucho mejor.

M. iiiSí!!!

T. La siento más tranquila, le veo un rostro diferente.

M. Sí, he estado más tranquila estos días.

T. Y con esperanza de mejorar las cosas.

M. Sí claro, yo creo que todo, porque nosotros lo hacemos es para él, porque nosotros cada uno ya vivió su vida... nosotros lo que queremos es que sea un hombre de bien. Yo me preocupo mucho por Julián, es por su futuro, yo no quiero que el día de mañana imagínese la fuerza que él tiene y la puede utilizar para mal, porque abi si acabaría conmigo... porque nosotros ahorita si ganaríamos muchas cosas, pero lo principal para nosotros es su bienestar, y si estas terapias me van a ayudar para eso pues...

T. Al respecto ¿̇ómo siente el proceso de esta ayuda?

M. Yo me he sentido bien, estado de ánimo mejor, más tranquila, me ha dado mal genio pero me controlo más y Julián si se ha ganado su correazo, ya no se lo voy a dar, sino que lo voy a mandar por allá para el parque.

T. A orientarlo.

M. Sí, como a sacarlo, a llevarlo al parque, que yo no tengo esa rutina.

N. Sí, tú nunca me sacas al parque.

T. Entiendo que por los miedos de la experiencia con el hijo menor. M. Sí, y que uno sale a la calle y uno no sabe a qué se expone. 
T. Importante encontrar sitios seguros.

M. Sí, he pensado en una casa en Mosquera.

T. Me parece una buena decisión.

M. Pues es que a mí me da miedo que uno no puede salir porque lo atracan, lo miran a uno, lo golpean.

T. Hay que tomar decisiones para mejorar su ambiente familiar.

M. Sí, yo creo que eso es lo que él necesita.

T. Un cambio en muchas direcciones.

M. Sí claro, total.

T. Esas decisiones son el resultado de su fortaleza.

M. Sí, y a mí me gusta mucho el campo, me crié en eso y me hace mucha falta, el aire.

T. Entiendo que su esposo es ingeniero y sabe del campo y le gusta también la energía suya, según nos lo ha expresado.

M. Será el mal genio (risas).

T. Él expresó que le gusta su energía, su coraje.

M. ¿Sí?

T. Sí, yo creo que encontró en usted una mujer de carácter y su temperamento bien manejado produce efectos positivos.

M. Tenemos la misma energía pesada, pobre hombre con nosotros (risas).

T. La siento decidida a reorganizar el viaje del barco.

M. Sí, con relación a Julián, lo que yo estoy viendo es eso, yo tuve la oportunidad de explotarla y él no la ha tenido y tenemos la misma energía entonces... porque igual mi papá me pegaba, me correteaba pero yo me iba y allá andaba todo el día, ya la correteada no era tanto... pero a él le toca quedarse encerrado todo el día y de pronto no explota todo lo que quiere.

T. Está muy cohibido

M. Sí, lo que yo le digo es que de pronto lo tengo muy encerrado, que nadie lo mire.

T. Peor entonces.

M. Sí, es como un animalito ahí.

T. Imagínese un leoncillo encerrado, en cambio si lo libera... recuerde usted el cuento de los caballos. 
M. Es cierto.

T. Usted misma lo vivió en carne propia.

M. Sí, yo lo viví y sé que es cierto, total.

N. (Susurra algo a la mamá).

M. Aborita amor, ya vamos a acabar... se me sienta acá.

T. Veo que él pide bien las cosas, eso está bien.

M. Él es muy tranquilo, creo que vamos bien, vamos bien.

T. ¿Cuál es la idea novedosa que sale de la conversación de hoy?

M. Que mi hijo habló (risas).

Dadas las dificultades en el manejo de la conducta de Julián, hay un orden pragmático que considero requiere ser reflexionado en el marco de la relación madre-hijo. En este sentido la madre percibe desde su lógica el manejo de la conducta de Julián con una premisa de control y este constructo de control que se va comprendiendo en la sesión está relacionado con su sistema de creencias y sus mitos culturales con los que fue formada; metafóricamente es como si repitiera la historia de ella con su padre y ahora con su hijo, siendo relevante para ella la premisa de control. Estratégicamente para cambiar la pauta rígida de control utilizo la metáfora del flujo de energía y evoco una anécdota hindú para generar reflexiones en la madre y el hijo en torno a la inteligencia de Julián y el manejo que hace la madre, lo cual permite que la madre entienda por sí misma su rigidez en el vínculo y la paradoja en la que se sitúa el niño. Pude ampliar además el marco ecológico del síntoma en tanto ahora se revela una historia de descalificación con el padre biológico de Julián y las alianzas establecidas en el marco de conflicto aún vigente de la primera unión.

La impresión que me deja esta sesión es que en cada paso de la terapia se van entendiendo los pliegues de una historia de sufrimiento, descalificación, confusión de vínculos y la síntesis de todo ese proceso en el síntoma. Valoro con mucha claridad la capacidad que tiene este sistema para continuar en medio de sus vicisitudes la construcción de la segunda unión, y veo que ese esfuerzo ha encontrado logros que aún no se han podido ampliar en razón a los relatos dominantes de la historia de origen. Entonces como en otros casos voy conectando las 
redefiniciones de la historia familiar con la construcción del nuevo sistema y esto lo hago en relación a la confianza que voy generando con la compenetración con el sistema consultante. De otro lado, reafirmo mis creencias en torno a la relación entre los órdenes de sentido de las historias y su conexión con los modos de vinculación de los sistemas; de igual manera creo en la inteligencia de los sistemas humanos para ir buscando intuitivamente sus transformaciones y cómo debo situarme como movilizador del cambio en los distintos subsistemas que estoy moviendo en el proceso terapéutico.

Experimento también la sensación de acople emocional y las claridades de sentido que están estableciéndose en el sistema terapéutico. Imagino entonces este proceso como una reconstrucción de un viaje en un barco que está ahora en un puerto para ajustar su ancla y reconstruir sus estribores, logrando con ello un viaje menos agitado que viabiliza la estabilidad emocional de Julián. Prescribo al niño el modo como debe utilizar su inteligencia, estratégicamente para manejar su situación sintomática.

\section{Comprensión del síntoma en una visión más ecológica. Configuración del sistema familiar de origen y su relación con Julián}

T. Lo importante es comprender lo que habló su hijo.

M. Pues la verdad con los psicólogos, lo he llevado a él y he tenido la oportunidad de ver y ellos lo manejan con medicamento. Pero a él nada le funciona, entonces yo he estado mirando que de pronto a él le ha afectado lo de mi otro bijo y él tiende a pelear con los compañeros y creo que él se siente como un perro que nadie lo quiere y que de pronto él me grita "ay yo parezco un perro, a mi todo el mundo me regaña, nadie me quiere".

T. Se van sumando partes de una historia de descalificaciones. Lo del padre, lo de la historia de la pérdida de su hermano, el rechazo en el colegio y se va formando una historia que condiciona a Julián como un leoncillo encerrado y descalificado.

M. Y nosotros lo veíamos era por el lado de la hiperactividad y de la grosería. 
T. Habían visto lo evidente pero no el otro lado que era comprender el sintoma, es decir, la conducta hiperactiva en cada una de esas situaciones.

M. Sí, nosotros no estábamos mirando eso, porque siempre le echábamos la culpa era al TDAH y que eso se arreglaba con medicamento, que eso era normal.

T. Es fácil decir que él es un niño con TDAH y medicarlo. Eso produce un control desde las funciones del cerebro, pero eso realmente no soluciona el problema porque incluso a veces desencadena mucho más la ansiedad.

M. Él duró como dos meses con medicamento y la profesora me lo sacó y me dijo: "acá vino y casi acaba conmigo" y yo le dije" pero si ya está tomando medicamento que fue lo que ustedes dijeron y no sé qué le pasa". Y la fuerza que tiene, si no es porque me cojo de la baranda me tumba.

T. El medicamento es una posibilidad pero muy limitada, estamos buscando otras lecturas.

M. Pues yo no he estado de acuerdo con el medicamento porque el esposo de la hermana de P consume medicamento desde niño y ¿cuál es el problema? Que él tiene que andar todo el día sentado y ya está acostumbrado y ya es un señor y usted lo ve y a toda hora es un señor que está dopado y el día que no se toma el medicamento se vuelve como ansioso y trata de caminar y se desmaya, y en estos días se cayó sobre el vidrio de la sala y lo rompió y Dios mío se cortó todo y él asi de grande. Yo no lo podía alzar y yo con esos nervios y él se paró y estaba normal y yo decía: uy no, yo no quiero que mi hijo pase por eso. Entonces yo hablaba de eso con P, que no estaba de acuerdo con el médico en eso, la pelea de él conmigo fue que él decía que el psicólogo había estudiado cinco años para tomar esa decisión y que quien era yo. Pues yo soy la mamá y a mí nunca me medicaron y aquí estoy.

T. Usted tiene mucha razón, por tanto ¿qué lectura se lleva a partir de esta sesión?

M. Pues que yo tenía la razón y que no tengo porque medicarlo (risas). 
T. Un ejemplo en usted misma.

M. Sí, ay Dios mío.

T. ¿Por qué dice "ay Dios mío"?

M. Es que P dice que ando loca.

T. ¿Usted cree en esa idea?

M. Yo no me como el cuento, ahora estoy entendiendo lo que pasa con mi hijo.

T. Y en esta historia que estamos construyendo poco se ha dicho en torno al padre biológico de Julián.

M. Él vino a buscarlo hace como cuatro años. Él se nos apareció en una calle por la que íbamos caminando y él nos abordó asi todo feo y se quedó mirándolo y me dijo: “¿ay ese es Julián?”, Y él dijo: "sí". Y dijo:" yo soy su papá" y Julián respondió: "no, usted no es mi papá, mi papá se acabó de ir a trabajar y lo acabamos de ver". Entonces se quedó mirándolo y le dijo: "no, yo soy" y yo le dije, "no, espere un momento, usted ya no es el papá de él, usted nunca lo determinó y ahora que lo ve grande ya viene a buscarlo" y el niño de una vez lo rechazó. Y él sintió el rechazo y se quedó así como que... qué pasó.

T. Y usted ¿cómo ha asumido la relación de su hijo con el padre biológico?

M. Yo a Julián le he tratado de decir así por los laditos, y le he dicho, papi igual todos cometemos errores y su papá no es que no lo haya querido, es que éramos muy jóvenes. Él quería terminar de estudiar, trabajar y él me contestó: "no me importa, el me abandonó y nunca me dio nada y me abandonó". Y me dijo: "yo por mí, me quito la sangre de él y me meto la de otro". Así me dijo. Bueno él me contesta así y él tenía seis años y hasta menos, imaginese.

T. Un niño inteligente en sus reflexiones. Sin embargo Julián necesita recuperar esa historia con su padre.

M. No lo determina para nada.

T. Ahora, si el papá nos escuchara hablar de esto ¿qué estaría dispuesto a mejorar en la relación con Julián?

M. Yo no sé hablar por A (padre biológico); pero lo que él me ha pedido es la custodia; pero igual él no es un hombre de darles afecto 
o amor porque mi otro hijo vive con la abuela y él lo ve; eso que vive con la familia de él, con otros hijos y otra familia y él se dedicó a sus otros hijos y a otro hogar y los tiene así como abandonados.

T. Entiendo la situación de Julián.

M. Sí, él no es un hombre de hogar.

T. Si mejorara el vínculo con su padre biológico, ¿̇usted no cree que mejoraría la vida de Julián?

M. No, no creo, porque él le ha mostrado rechazo.

T. Precisamente podría cambiarse la historia de un niño agresivo.

M. Sí, eso es claro, por eso le digo que me le voy por el ladito porque uno no sabe que después los dos estén en tratamiento.

T. Válido su razonamiento al pensar en el futuro de ellos dos.

M. Sí, claro, porque Julián con su temperamento y ya siendo un hombre y encontrarse con él pues... si es como yo, sincero, le va a decir todo lo que piensa así como le sale y él debe recordar que él es su padre, entonces el respeto ante todo.

T. Previendo ese encuentro, podríamos pensar en invitarlo.

M. Sí, yo le digo para que él lo piense a ver si viene.

T. Esa es una posibilidad por ahora.

M. Llevo ocho años que no dialogo con él; solo de las mensualidades que toca pagar y ya; nos encontramos un día o un fin de semana y no más.

T. Y si usted hablara con él... para cambiar esa historia por el bien de todos...

M. ¿Pero hablar en qué sentido, decirle que se preocupe más por Julián?

T. No, que hay asuntos con Julián que hay que resolver para satisfacción de él y de Julián; no están obligados a amarse pero sí a respetarse y esto que ha pasado entre los dos ha afectado a Julián... que si él quiere ser digno de lo biológico como padre, esto podría ayudarle a Julián.

M. Pues de hablarlo podría hablarlo.

T. Solo si le es posible.

M. Pero quizás no se preste mucho para eso porque lo que yo le decía, él no es un hombre asi de sentimientos, de ser afectivo. 
T. La conversación no significa ser cariñoso, lo importante es cerrar ese capitulo con Julián; al cerrar capitulos pendientes, estamos sanando corazones.

M. Sí, también.

T. Todos podemos mejorar nuestras historias, usted lo está haciendo.

M. Sí, igual yo le dije a Julián. No importa lo que haya sido, usted nunca vaya a coger y que si se lo encontró y le va a pegar, que si no se lo encontró... Yo le dije: "déjelo ahí, igual a usted no le hace falta porque a usted no le hace falta nada". Y me dijo: "sí, igual yo no lo quiero volver a ver", pero entonces yo le puse la propuesta de que si él algún día aparecía que él qué hacía y me dijo: "mami yo no le hablo".

T. Lo importante es que esa historia sea sana, no importa que no se quieran pero que se respeten.

M. Sí, el respeto sí, claro.

T. Al respecto conversaremos después. Ahora quisiera saber cómo es la relación de Julián con el hermano mayor.

M. No le he preguntado... pues no sé porque uno llega y por lo menos Julián me defiende a mí y defiende a P. Mi hijo mayor llega $y$ es asi un poco como creído, como café con leche, mejor dicho como estirado, entonces viene y dice, mami no le hablo a ese indio (refiriéndose a P), porque usted dejó a mi papá y no vuelve con mi papá. Y Julián le contesta: "cuál indio respete a mi papá" y el otro le contesta: "ese no es su papá”, y empiezan a discutir.

T. Esas historias son las que hay que sanar.

M. Y entonces yo digo: "un momento usted se me va para acá y usted para allá pero ustedes acá se me respetan porque están en mi casa". Y le digo a mi hijo mayor: "usted no tiene por qué venir a hablar del papá de él porque él no habla de su papá. Me hacen el favor y se respetan, su papá tiene su hogar, yo tengo otro hogar y ahi ustedes no se van a meter".

T. La relación entre los hermanos debe mejorar, pareciera una familia dividida en bandos.

M. Sí, total. 
T. Entonces todos deben resolver sus historias y ganar confianza en las relaciones como familia.

M. Pero no. Mire que en estos días hablando con mi hijo el mayor, vi que estaba muy dolido y yo iba con mi esposo y con Julián y lo vi por donde yo vivo y le dije: "¿amor usted qué hace por acá?”, $y$ me dijo: "no mami es que voy a hacer un mandado", y me dijo: “¿para dónde van?” Le dije: "voy a comer hamburguesa”, y me dijo "¿puedo ir?" Y yo pensé que pues tan raro que si puede ir con nosotros en el barrio y eso no es normal y yo le dije: "ay no mi amor, es que usted se pone a pelear, entonces mejor mañana vengo y comemos los tres solos." Bueno, no importa, yo quiero ir, entonces si quieres lleva el mandado y yo voy y te recojo, entonces yo fui al sitio, vi a Julián y a $P$ y fui a recogerlo y salió del baño increíble y yo decía iive!!!... Y me dice: "mami estoy muy triste" y le dije: “¿qué pasó?” "Es que mi papá va a tener otro bebé, otro hermano y yo me pongo a pensar todo ese motón de hermanos, hijos del uno y del otro regados", y él tiene diez años... Y él me dijo: "la verdad yo no quiero tener más hermanos, yo solo quería a Julián, a mi hermano perdido... pero dos hermanos más yo..."

T. Está decepcionado del padre biológico.

M. Él mismo se decepcionó de su papá. Él me dijo: "él solo tiene tiempo para ellos, para su familia y yo aquí con mi abuela."

T. ¿Él no ha pensado en integrarlo al núcleo de su familia actual?

M. Sí claro, él ha querido integrarlo pero el abuelo nos lo recomendó porque dijo que él ya había sufrido con la abuela y ya le había dado muy duro.

T. Lo que tenemos que buscar es una mejor estabilidad para el niño, aquí tenemos que recomponer el barco, para que quede todo como organizado, cada uno con su viaje.

M. Claro, yo vi que mi hijo si quedó bastante afectado con eso.

T. ¿Y abora cómo está la situación?

M. No, pues él ya empezó que su hermano y su hermano y se fueron a jugar micro los dos. Entonces yo sé que da miedo de integrarse a las cosas así, pero entonces uno como papá cuando el otro dice 
"ay usted es una mentirosa que siempre me echa la culpa a mí," es bonito que ellos mismos se den cuenta de cómo son las cosas y que uno no les está diciendo mentiras. Igual yo le dije: "papi igual tú tienes que respetarla porque ella no tiene la culpa, tú te pones a decirle que esa india que esos niños, abi el culpable es su papá."

T. Entonces usted les recomienda a sus hijos que se vayan a vivir con usted.

M. Es que también tengo otro problema, es que P se hizo cargo de Julián pero hay veces que me rechaza al niño mayor y no me lo deja entrar al apartamento.... Entonces el problema de estos años de yo dejar de verlo fue por eso. ¿iSe acuerda que comentábamos lo de las familia y todo? La cuestión era que era mucha familia para acá, se murió la abuela y era venga la familia cada ocho días, la rumba, a tomar traguito y todo el mundo se iba, para la navidad era igual, la casa se llenaba, comida para todo el mundo y nosotros no somos tacaños. Siempre hay para todo el que llegue, igual no tengo problema en eso, pero yo digo: listo si viene su familia, ¿por qué mi hijo no puede venir? Si es mi hijo y es navidad y navidad es para los regalos de los niños, nosotros donamos regalos en navidad, compramos regalos extras para el niño que necesite.

T. Entonces hay necesidad de continuar el proceso de reorganización de su familia.

M. Claro.

T. Muy bien, por hoy hemos terminado, continuaremos en la próxima sesión. Le recuerdo que la próxima sesión es con su compañero.

M. Gracias.

El proceso de intervención está produciendo una clara redefinición del problema al comprender que el comportamiento del niño, no es un asunto biológico y voy viendo con mayor claridad que la madre ha hecho un entendimiento racional del problema. En este mismo sentido vamos conectando la siguiente página de la historia, como lo es la relación de Julián con el padre biológico, la relación de la madre con su hijo mayor y cómo se está reconstruyendo la historia de los 
vínculos de la madre con sus dos hijos. De igual manera se hace necesario establecer como parte de esta construcción los límites necesarios con el padre biológico, dadas las necesidades urgentes de protección para con los niños.

De otra manera pienso cómo se está organizando la nueva estructura familiar y para ello relaciono la postura del compañero de la madre, el cual está ya dispuesto a formalizar el rumbo de la estructura nueva. Noto en la madre una mayor claridad en su rol como tal, experimento una persona más clara y saludable para establecer los cambios necesarios; ha hecho un despeje de su sufrimiento y su dolor y el porvenir del sistema familiar está siendo consolidado.

En este proceso se reafirma mi convicción acerca de cómo todos los sistemas humanos son suficientemente capaces de encontrar sus propias soluciones y de que mi postura como terapeuta es la de viabilizar el contexto para producir el cambio.

\section{Quinta sesión}

En esta sesión asisten la madre y su hijo, se esperaba la madre y el padrastro, sin embargo, dado el tipo de trabajo de $\mathrm{P}$, no pudo hacerse presente. Se asumió trabajar entonces con el sistema madre-hijo.

\section{Evaluación de cambios, y ajuste de los patrones de interacción madre-hijo}

T. Buenas tardes ¿cómo se encuentran?

M. Sí, señor, bien sí, señor.

T. Supongo que el padre sigue trabajando afuera.

N. Sí, sí.

T. Podemos iniciar primero evaluando cómo nos ha ido esta semana.

M. La profesora otra vez dice que no ha mejorado, que está cada vez peor y lo mandaron a comité estudiantil.

T. ¿Entonces qué piensa Julián?... ¿Qué pasó Julián?

M. Él no está comprometido, no sé qué le pasa.

T. ¿Qué pasó con la inteligencia?... ¿Se te perdió la inteligencia?... ¿Y a qué se debe que se pierda la inteligencia?... 
N. A no usarla.

T. A usarla, sí claro y ¿qué pasó para no usarla bien en ese momento?

N. No lo sé.

T. Es clave que empieces a identificar por qué pierdes la inteligencia en el manejo de la ira. Cuéntame que pasó con los niños y con la profesora en ese momento.

M. Que un niño estaba jugando y él lo cogió a golpes.

N. No, estábamos jugando cogidas.

T. ¿Y qué pasó?

N. Que yo lo iba a coger cuando él se pegó.

T. ¿Y fue brusco?

N. No, no, yo lo cogí, se enredó y se cayó y él se enojó conmigo.

T. ¿Y qué hizo inmediatamente?

N. Lo fui a coger y se quedó ahí hasta que llegó la profe.

T. ¿Y usted hizo algo para ayudarle?

N. Sí, yo le iba a ayudar a pararse, a sentarse en el puesto pero tenía mucho dolor.

T. Si le hubiera ayudado más directamente ¿cómo lo hubiera hecho?

N. Ayudarlo a sentarse, a sentarse en el pupitre.

T. Correcto, y si lo hubiera hecho, ¿cuáles hubieran sido esas razones?

N. Porque le dolía mucho y se quedaba en el piso llorando.

T. Si estuviera en la situación de él, ¿̇qué esperaría que hicieran con usted?

N. Que me recogieran y me llevaran al puesto.

T. Un acto de solidaridad.

N. No dejarme ahi tirado.

T. Asi es, ser solidario en la situación, y al respecto pedirle excusas.

N. Sí, pero la profe siempre es brava conmigo.

T. Lo entiendo, ¿y cuándo fue ese incidente?

M. Mmm el viernes.

T. ¿Y antes del viernes cómo estuvo?

N. Bien.

T. Duró varios días sin dificultades, eso está bien.

M. No, también les ha pegado a unos niños, pues eso es lo que ella dice y uno le pregunta a él y él dice que no; ella dice que él se 
porta mal y él siempre se excusa diciendo que la profe es la que no le pone cuidado.

N. Es que es verdad, es verdad.

T. ¿Entonces quiere que la profesora le proteja?

N. Si me pegó o me pegan, ella nunca hace nada.

T. Entonces es como si fueran injustos con usted, es decir cuando le pegan y nadie reclama nada, pero cuando usted pega abí si lo sancionan.

N. Sí, es así.

T. Entiendo.

N. Siempre citan a mi mamá...y a nadie más, siempre a mi mamá.

T. Se hace necesario conversar con la profesora. Vamos a invitarlos a conversar, por ejemplo a la profesora ¿a quién podríamos invitar?

M. La coordinadora, la administradora y la profe, ella fue la que nos recomendó acá. Yo no sé si ellos asistan.

T. Sí no asisten se haría otro tipo de coordinación. Y por otra parte ¿cómo va en casa?

M. En la casa ha mejorado.

T. ¿Qué quiere decir eso?

M. Pues hace más caso, ya no se sale sin pedir permiso, ya está más tranquilo

T. Vamos por buen camino.

N. Ayer no me salí porque estaba estudiando.

T. Muy buena razón. ¿Qué es mejor para la mamá, que haga caso o que esté tranquilo?

M. Las dos cosas, que haga caso y esté tranquilo.

T. Se hace necesario hacer una diferencia. Hacer caso es como si uno fuera una ovejita descarriada, en cambio estar tranquilo es no necesitar el control para hacer lo necesario. A menos control, usamos mejor la inteligencia. La madre también tiene que usar la inteligencia. ¿Usó la inteligencia esta semana?

M. Sí, esta semana hizo sus tareas y lo dejamos salir un rato a jugar micro.

T. Veo que han ido mejor. 
M. Estos días ha mejorado. Igual yo hablé con él y yo le dije que él es un hombre ya, ya él está grandecito y si él no pone de su parte nadie va a poner de su parte.

T. Buenos consejos de mamá.

M. Porque él es el que va a sufrir, porque yo no soy la que va a estudiar.

T. Otro buen consejo.

M. Y la profe lo regaña para que se quede quieto en el puesto y yo le digo que no se levante del puesto, porque le echan la culpa.

T. Pero no es tanto que se quede quieto, si no que se comporte aceptando inteligentemente las reglas.

Entendiendo el objetivo principal de esta quinta sesión que es evaluar los cambios en los diferentes órdenes del sistema para hacerlos sostenibles y más expansivos, identifico ligeros cambios en el comportamiento de Julián en el colegio y grandes en la casa, lo cual me lleva a pensar que la intervención sobre el contexto familiar está produciendo resultados específicos en el niño, mientras que en el colegio, el patrón de rotulación continua existiendo, como se puede ver en los episodios narrados.

Reafirmo cada vez más que la hipótesis en torno a que el comportamiento de Julián está en relación con cómo se vincula con los sistemas parentales y sociales. Animo intencionalmente el mejoramiento de la pauta de vinculación con la madre, especialmente porque creo que la madre está en la dirección del cambio de su pauta emocional con el hijo y hay que reafirmar estos cambios para generar un sistema protector estable con Julián.

\section{Modelización de los patrones de la madre en la interacción con el hijo y ampliación de la visión de los sistemas amplios de protección}

M. Sí, entonces la psicóloga estaba diciendo que de pronto era un signo de un desorden comportamental. 
T. Otro diagnóstico.

M. Sí, ella dijo que era eso.

T. El problema es cómo relacionarnos con Julián para educar sus emociones y que aprenda a relacionarse consigo mismo y con los demás.

M. Pues, él en la casa es normal, si pero él tiene su movimiento y todo, pero igual como yo ya vivo con él, yo me lo aguanto, lo controlo, pero ellos no; ellos se quejan es de eso, a toda hora que él se sale y se mueve y aparte de eso que es agresivo, entonces por eso lo mandaron a comité estudiantil, como para sacarlo del colegio otra vez.

T. Vemos la necesidad de comunicarnos con el colegio, podemos enviarle una carta para que comprendan la situación de Julián.

N. Yo pienso que sí.

T. Julián puede escribir también una carta al colegio usando la inteligencia.

N. No sé.

T. Bueno, después hablamos de ello; la mamá puede ayudar a escribir la carta.

M. Yo le dije a la profesora que si pedía un diagnóstico y ella me dijo que no, que no porque el comportamiento de él no ha mejorado.

T. ¿Y eso si es cierto? ¿que no ha mejorado?

M. En el colegio no mejora pero en la casa sí es normal, sí ha mejorado en la casa.

T. Entonces en parte si ha mejorado.

M. En la casa sí, pero porque vive conmigo, entonces yo abí lo controlo.

T. Más que controlarlo, lo ha ido entendiendo como persona; por eso se hace necesario que el colegio participe en esta ayuda.

M. Sí, pero ellos se excusan en que no, que es grosero, que yo no sé qué más...

N. Porque la única profesora que me defiende es la profesora Nancy.

T. ¿Quién es Nancy? 
N. Mi profe que yo tenía antes en el curso.

T. Ella le defiende. Entonces en el colegio tiene personas que le defienden y que le acusan. Está como ante un tribunal.

M. Y esta semana también se perdió un teléfono en el colegio.

N. Y empezaron a echarme la culpa a mí.

T. Está rotulado en el colegio y ¿qué hizo cuando eso ocurrió?

M. Nosotros fuimos y nos quejamos con el director y nos pidieron disculpas porque igual le gritaron feo.

T. Parece como si fuera una arbitrariedad.

M. Sí, ellos dijeron que disculpas, porque como yo estaba en clase yo me demoré veinte minutos más, yo llegué como a las cinco y cuarenta, yo tenía clase, iban a ser las seis, faltaba un cuarto y ya había empezado el problema con él. Lo tenían encerrado revisándolo; le decian que él se había robado el celular y llorando decía que no se lo habia robado y ya le habian revisado todo y él dice que la otra profesora lo agredió.

N. Ella me cogió de acá (señalando el cuello) y me tiró al piso para poderme esculcar.

M. Pero, ella dice que no es cierto.

N. Sí.

M. Que no es como uno cree y ella nos miraba y yo le dije que si volvía a suceder yo la demandaba, porque eso era un abuso y yo le dije por qué lo revisaron, si nosotros siempre estamos pendientes de él a la hora de la salida; por qué no nos esperaron a que llegáramos y entonces ellos se asustaron al ver que los íbamos a demandar; el director llegó y nos pidió disculpas, que iba a hablar con la profesora, que igual ella lo negaba, que de pronto el niño estaba mintiendo y que le había parecido que lo había jaloneado, dijo así.

N. Pero, es cierto.

M. Pero Julián debe saber qué le hicieron o qué no le hicieron.

T. Si todo esto es verdad, realmente es un abuso. ¿Qué piensan ustedes como padres acerca del manejo que hizo el colegio?

M. Ese es el único colegio que lo pasaron, de primero lo pasaron a segundo porque él sabe mucho y el comité pensaba promoverlo 
a cuarto o a quinto el año entrante; ya a esta altura es muy grande para los otros niños y ellos no lo ven haciendo segundo.

T. Ahora está más grande y más consciente.

M. Le cambiaron la jornada el año entrante, pasa para por la mañana.

T. Es importante hacer entender la dificultad de Julián también al colegio, haciéndoles saber también que hemos avanzado.

M. Esto es un altibajo.

T. Un altibajo; el comportamiento de Julián racionalmente muestra un niño grande; en las relaciones emocionales un niño pequeño, entonces, ¿qué hay que hacer Julián?

N. Igualarlo

T. Igualarlo, y si lo iguala ¿qué va a pasar?

M. Ella (la profesora) dice que si mejora su comportamiento ella lo promovía a otro curso en el colegio, porque él es muy inteligente. T. ¿Sí oyes Julián?...

M. Para no haber estudiado en el colegio estos años él sabe leer y sabe multiplicar y todas esas cosas; por eso lo promovieron.

T. Entonces hay que continuar, no bajar la guardia con su actitud de cambio. De esta manera, así como vuela la inteligencia racional, debe crecer la inteligencia emocional; hay que ayudarle a crecer emocionalmente. Un buen ejemplo es la forma como se vuelan las cometas. ¿Sabes cómo se hace para volar las cometas?

N. Mmm.

T. ¿Cómo hacemos para elevar la cometa?

N. La echamos al aire y vamos halando.

T. ¿De qué depende que vuele?... Del aire para que vuele: si hay aire la soltamos, si no hay aire, la recogemos.

N. Yo tengo una primita que ella compró una cometa que voló alto, alto, altísimo.

T. Asi es que queremos que vuelen las emociones de Julián. ¿Qué piensa la madre, qué piensa de soltarlo?

M. ¿En qué sentido?

T. En el manejo emocional de Julián. Cuando las maneje bien soltarlo y cuando no, va recogiendo. 
M. Es que con él es difícil.

T. ¿Qué quiere decir con que es difícil? Emocionalmente...

M. Personalmente, de conectarse emocionalmente... no sé, de premiarlo, darle algo...

T. ¿Qué pasaría si se aproximara más en la relación madre-hijo?

M. Sí, de pronto.

T. ¿Qué quiere decir con de pronto?

M. Como el actúa como un hombre ya tiene su libertad y yo tengo la mía.

T. Así seamos grandes necesitamos una expresión emocional de la madre, como un beso.

M. Pues sí, él duerme conmigo.

T. Se hace necesario resolver esas paradojas; que duerma con usted es un trato de bebé. Se hace necesario un beso y un abrazo de grande, tratarlo como grande pero con afecto, cambiando el modo de relacionarse con él.

M. Pero él ha mejorado, cuando él se porta mal yo no le hablo, lo dejo por allá, lo dejo aislado.

T. ¿Qué pasaría si cuándo él se porta mal le aconseja saludablemente?

M. Es que yo voy y le hablo y él se pone grosero y yo me voy; se pone altanero, o sea grosero y empieza: no escucho, no me hable y no le hablo así grosero y salgo y no le vuelvo a hablar. Es que cuando él se pone de mal genio es tenaz.

T. Entiendo que educar a los hijos no es fácil; sin embargo, los padres aprendemos a relacionarnos de una manera que podamos entenderlos y vamos descubriendo nuestras propias claves. Porque usted hace cosas bien, cuyo resultado es tener un niño inteligente; pero su forma de reaccionar emocionalmente en ocasiones no es la apropiada pues no le ayuda a él. Los padres también necesitamos crecer emocionalmente. Usted se incomoda cuando él hace algo mal, la entiendo, pero el asunto importante es cómo usted como madre, maneje la ira.

M. Sí, de pronto.

T. ¿Qué quiere decir de pronto? 
M. Yo soy calmada, pero hay veces que me desespera y pierdo la paciencia y lo grito.

T. ¿Cómo es esto de que usted pierde la paciencia?

M. Entonces le digo, váyase para la pieza y no moleste.

T. ¿Y entonces cómo educó al hijo mayor?

M. Mi hijo mayor como se crió con la abuela...

T. Entonces usted al único que ha criado es a Julián.

M. Sí, pero mi hijo mayor él sabe que yo tengo un carácter fuerte y apenas yo le hablo él me hace caso a pesar de que no vivió conmigo.

T. Usted puede hablarles con carácter fuerte, pero con amor, ¿qué diferencia encuentra usted entre hablarles fuerte con amor y fuerte con ira?

M. Mmm

T. Hagamos la distinción ¿Qué diferencia encuentra usted?

M. No claro, que él se siente agredido sin amor y con amor que él se sienta regañado.

T. Se siente educado con amor.

M. Sí, eso es lo que yo le digo a él, cuando los regaño no es porque yo quiera regañarlos o porque yo no los quiera; es porque los tengo que educar y yo le he dicho que los corrijo, yo lo estoy educando y él se pone a llorar, pero después él entiende y me pide disculpas y ya no me enojo con él.

T. Esa es una clave para educar a Julián con amor.

M. Cuando lo corrijo a él... yo siempre lo corrijo con amor, lo que pasa es que hay dias que me desespera, por ejemplo el día del celular yo creo que él estaba asustado porque creía que yo iba a subir a pegarle y no, yo le dije a Julián “¿qué pasó?”

T. Muy bien, usted reflexionó.

M. Y él me dijo: "no mamá, que la profe me está culpando." Y yo me quedé ahi parada, cuando yo vi que ella vino a pedirlo, yo le dije: "no, usted no puede agredir a mi hijo." Le dije: "iusted le encontró el celular?" "No", entonces usted no puede culpar a mi hijo de que es un ladrón, usted no puede agredirlo. Y yo me vine con Julián hablando todo el camino y él me asegura que no; 
entonces no es que a toda hora lo voy a acusar, no, yo tenía que preguntarle su versión, y yo le dije: "sí tú no te lo robaste, o de pronto si lo cogiste, no es que te lo hayas robado, sino de pronto es porque le tienes bronca a la profesora, uno no está seguro; ¿le querías hacer una broma? Pero fue pesada. Y ya cuando viste que se te formé el alboroto entonces lo niegas." Yo le dije: "dime dónde está y yo pongo la cara y lo devolvemos."

T. Muy bien, usted asumió una postura de protección, de reflexión $y$ de análisis.

M. Sí, y el asegura que no se lo robó.

N. Es que la profe no me escuch a mi verdad.

T. Veo que usted como mamá está mejorando en la relación con Julián.

N. Sí.

T. Vea usted, su hijo le reconoce el cambio

N. Cada vez me dice Julián, ahí vas mejorando poco a poco, poco a poco, vas mejorando poquito a poquito, poquito.

T. Ese poquito es importante y ¿qué es lo que hace la mamá para que usted vaya cambiando poco a poco?

N. Me dice: "Julián, no te portes mal para que no te vayan a regañar, después te regañan y te llevan a coordinación", y yo: "sí mamá, pero a mí casi no me llevan a coordinación."

T. Entonces, su mamá le trata inteligentemente.

N. Sí.

T. ¿En qué ha mejorado ella en la relación con usted?

N. En cómo hablarme bien.

T. Podemos felicitarla.

N. Sí.

T. Mamá, felicitaciones ¿y cómo podríamos seguir mejorando?

M. Sí, lo que pasa es que yo con él tengo una buena relación; lo que pasa es cuando yo le hablo y le hablo, digamos, toda una semana hablando con él, le digo Julián no le vayas a pegar a los niños y él sigue, les pega y yo hablo todo el camino con él y la semana completa me la pasé así. Y llega el viernes y yo tranquila y entonces él me desespera porque me da a entender que no me está haciendo 
caso y que lo que yo le digo no vale, o que no está entendiendo lo que uno le dice; entonces yo le pregunto a él por qué, que es lo que quiere, entonces él no responde.

T. Entiendo que ustedes quieren mejorar la forma de relacionarse.

N. Yo sí.

T. ¿Cómo hacemos para cambiar esa pauta?

M. Julián se tiene que portar bien.

T. Vea usted la pauta. Si Julián se comporta bien, usted se comporta adecuadamente, pero si él se comporta mal, la madre se altera y condiciona la relación, esto parece una forma de chantaje.

M. No, pero es que todo se basa en el comportamiento de Julián, es que es como su lenguaje.

T. Podría usted leer la reacción de Julián como una llamada para que usted lo trate como un niño inteligente.

M. Sí, pero él también tiene que comprender que cuando uno no se gana el respeto, uno no puede ir a exigirlo; exigir respeto a un compañero cuando uno lo ha golpeado todo un año.

T. Estamos de acuerdo, él también tiene que utilizar su inteligencia para comprender las situaciones.

M. Tú cómo le vas a exigir a un compañero respeto, que él te golpeó una vez y tú lo golpeaste todo el año, no le puedes exigir que no te golpee, ¿cierto?, yo te he dicho y entonces él en ese momento...

T. Él debe entender el efecto que produce con su comportamiento en los demás.

N. Que no debo pegarle.

M. Y todos los días, él todos los días le pegaba y el niño se cansó y le pegó.

T. En esa situación ¿̇quién pierde Julián?

N. Yo.

T. Julián termina en una especie de trampa. Y de nuevo, ¿quién pierde?

N. Yo.

T. ¿Por qué cae en su propia trampa?

N. Mmm.

T. Digámosle a la mamá que le ayude a salir de la trampa. 
M. Porque cada vez que tú hagas una acción, ellos te van a acusar a ti y van a verte como el malo; porque tú los golpeas cada ratico, y ya no te creen que el día que él te golpeó tú estabas diciendo la verdad, siempre te ven por el lado negativo.

T. Asíes.

M. De que Julián golpea siempre y yo también digo ellos también tienen la razón, porque están cansados de que él los maltrate.

T. Con una vez que actúe mal, generalizan, por eso se hace necesario que el colegio entienda la pauta.

M. Pero a él le realizaron una terapia, la psicóloga entró al salón y lo paró al frente de sus compañeros y los niños le dijeron lo que no les gustaba de él, y le hicieron una terapia y él se puso a llorar porque los niños lo abrazaron. Entonces le dijimos que tenía que entender que los niños sí lo querían, pero que por su comportamiento, como él los golpeaba, ellos le tenían miedo; además, le dijeron palabras muy lindas, ¿cierto?

T. ¿Qué le dijeron Julián?

N. Que me comportara, me abrazaron.

M. Pero, eso no significa que esté golpeando a sus compañeros.

N. Pero no sé por qué, es que me desesperan no sé por qué, eso no lo entiendo.

T. Es como si perdiera el control, ¿y qué hace cuando estás alterado?

N. Pues le pego a alguien.

T. Y en ese momento ¿qué sientes? o ¿qué piensas?

N. No sé.

T. Parece que la ira es una emoción difícil de manejar, le perturba. ¿Cómo le han enseñado a manejar la ira en casa?

T. Le digo que cuente hasta diez.

T. ¿Y lo hace?

M. Sí, gracias a Dios.

T. ¿Y la mamá? ¿Cómo maneja las emociones?

M. Yo me encierro y no hablo con nadie.

T. Ah, se toma su fuera de tiempo. 
M. Pues, si está molesto enciérrese en su habitación, mire a ver qué hace para no tratar mal a los demás.

T. También la ira se puede interpretar como una energía que se puede canalizar en un deporte.

M. Sí, pero como el horario del colegio no le sirve, entonces estamos esperando ahorita el cambio de jornada, ahora sale a las seis, muy tarde.

T. Como veo, necesitamos varias estrategias para avanzar en el cambio. Uno, mejoramiento de la relación de los padres con Julián para educarlo sabiamente; dos, el mejoramiento de la relación de ustedes como padres para mejorar el ambiente familiar y estar de acuerdo para dónde va el barco. Tres, canalizar la energía de Julián en deportes; cuarto, conversar con el colegio acerca de mejorar el modo de manejar la situación con Julián; quinto, el desarrollo de la conciencia de Julián acerca de su comportamiento y sexto ampliar las redes sociales de Julián; al respecto, quisiera saber cómo llevan la relación con su hermano mayor.

N. Bien, pero él también se comporta mal allá en el colegio.

M. Sí, por ahi están diciendo que también se comporta mal.

T. Entonces Julián no es el único que se comporta mal. Me gustaría mucho poder conocer la relación de Julián con el hermano. Porque una cosa que me preocupa de Julián es que él necesita relaciones que lo ayuden a crecer emocionalmente y el aislamiento es contraproducente, no sé si fui claro.

M. Sí.

T. Si hay riqueza de relaciones Julián no se sentiría aislado, y a veces pienso que se siente aislado, entonces sería muy importante animar los vínculos con el hermano. Si mejora la relación con sus hermanos se sentirá mejor y vivirá la vida más solidariamente.

M. Sí, este fin de semana tuvimos un cumpleaños familiar y yo los recogí a ellos como para que estuviera con todos y yo traje al otro chico; sí el hermano por parte de papá que tuvo, pues yo me los traje a los dos.

T. Estas prácticas hay que continuarlas. 
M. Ellos estuvieron los tres.

T. Entre más hagan actividades que fortifiquen las relaciones, mejor.

Comprendo con mayor precisión la pauta emocional de Julián, en tanto a mayor grado de descalificación de él en el marco de las relaciones familiares y escolares, mayor incremento de la pauta agresiva y busco reconocer el mejoramiento del vínculo de la madre con él; para lo cual estratégicamente desarrollo un proceso narrativo conversacional e interaccional con las acciones de la madre por medio del cual quiero generar una elaboración deliberada de esquemas para dirigir la acción de la madre en la relación con Julián; hago también extensiva la modelización a las acciones del niño y reconozco la disposición al cambio de ambas personas. Describo las metáforas de la cometa, la pauta de chantaje, las metáforas del amor y experimento en la madre de Julián una disposición para mejorar sus procesos de interacción y observo como las metáforas utilizadas facilitan la comprensión de la madre en su rol de educadora.

Veo la necesidad de ampliar el marco de acción del self de Julián y de cómo los modos y grados de vinculación con sus padres, hermanos, compañeros de colegio, profesores juegan un papel trascendental en el desarrollo de la personalidad de Julián y en la modificación de su patrón interaccional; busco en este instante ampliar las redes eco sistémicas de vinculación del niño. Atribuyo una fundamental importancia a que al expandir los sistemas de protección del niño, él obtendrá más cambios positivos en su adaptación.

Me sorprende el grado de apropiación con que el niño asume el proceso, reconozco el compromiso de la madre en el cambio y su forma de vinculación con el niño; valoro el rumbo que ha tomado el sentido de la historia de esta familia y el mejoramiento compartido de las formas de vinculación de todos sus miembros.

Creo necesario enviar un reporte al colegio que garantice un efecto protector para Julián e incluyente para este sistema. En este sentido envío una misiva, cuyo contenido se describe al final de la sesión. 


\section{Evaluación y cierre del proceso ${ }^{4}$}

T. Finalmente, evaluemos un poco los avances obtenidos en este proceso hasta aquí. ¿Qué ha dicho $P$ al respecto?, ¿qué ha aportado al cambio?

N. Sí, un poco, un poco, ya me habla mejor, me dice Julián ve al baño, te bañas, ya está mejorando, mi mamá le explicó cómo es que se tiene que comportar conmigo.

T. Reconozco que usted, mamá se alegra con el cambio de Julián.

N. Cuando me porto bien en el colegio.

T. Entonces se siente orgullosa de usted.

M. Es que él sabe y la profe dice que este semestre ya finalizando el año, estuvo bien, no le fue mal, pero ella dice que le puede ir mal si no escribe, que él no quiso hacer nada, pero como que va muy veloz.

T. Pero ¿si escribe o no?

M. Sí, escribe pero no completa las cosas, las deja a medias y se va, se sale del salón.

T. ¿Y no han hecho prácticas de eso?

M. Yo lo tuve este fin de semana haciendo la carta.

T. Sí, es importante. Al respecto yo enviaré un reporte al colegio con copia a ustedes.

$M$. Le recordé, pero entonces, ella dice que no es porque él no sepa, sino que no quiere mejorar su rendimiento académico, entonces, yo lo regaño porque le digo fuera que no supieras, pues uno dice es que se disculpa, pero si sabes, por qué sacas malas notas.

T. Ese es el dilema; sí, él sabe que es inteligente; el asunto es animarlo al cambio y a su crecimiento.

M. Sí, igual y le soy muy honesta, yo le corrijo mucho la ortografía, nos ponemos los dos y yo le enseño, pues cuando él no estudia yo le enseño a leer, todo lo que sabe.

4 Ante la eventualidad del cierre de la IPS por el periodo académico inter semestral, implemento esta fase final de evaluación y cierre del proceso, advirtiendo en todo caso al sistema consultante la posibilidad de continuar el proceso si fuere necesario. 
N. Sí, mi mamá es la que me enseñó a leer.

T. Qué bien.

N. Porque yo no estuve en jardín.

T. Podemos entonces avanzar en torno a los cambios en este proceso. ¿En qué más les ha servido?

M. Sí, claro. De pronto para darnos cuenta que a veces cometemos errores y uno no los ve. Si, uno no siempre está en disposición y nosotros necesitamos una persona que nos asesore bien y nosotros hemos mejorado la comunicación con P, nuestras diferencias las hacemos aparte.

T. ¿Y en relación con Julián?

M. Para mi sí, en la casa ha mejorado.

T. Y ustedes como padres ¿cómo se encuentran?

M. Estamos tranquilos.

T. ¿Y ha pasado la angustia y el dolor que tenían?

M. Si estos meses he estado tranquila.

T. Me alegra mucho que emocionalmente estén mejor; y Julián ¿de qué le ha servido este proceso?

N. Mmm, mejorar un poquito, mejorando un poquito a mejorar el comportamiento con mi mamá.

T. ¿Qué piensa la mamá?

M. Que sí, igual Julián es mi compañía. Pues yo lo saco a todo lado.

T. Me decía también que habia avanzado en la relación con su compañero.

M. Sí, pues ya estamos mejor.

T. Lo que siento es que usted se está superando mucho. Me alegra porque la impresión que tengo es que usted es clave para su familia, tanto para con Julián, la niña y su compañero. Usted sabe bien el papel que tiene en su familia.

M. Sí, claro, uno como mujer es la que guía un hogar.

T. ¿Y a usted le gusta guiar el hogar?

M. Sí, claro.

T. Bueno, hemos terminado por este semestre, mil gracias por haber confiado en nosotros.

M. A ustedes también. 
T. Pueden volver a consultarnos a inicio del semestre si lo requieren. Si no lo requieren indica que ustedes han avanzado en el cambio. En todo caso haremos una llamada de seguimiento del caso. Julián chao, que estés muy bien.

La intención de esta parte final de la sesión, dada la novedad de corte del proceso, fue la de evaluar los cambios obtenidos en las relaciones de los padres, de la madre y el hijo y del sistema familiar en general. Indago sobre el efecto del proceso y encuentro un reporte de mejoramientos en el sistema parental, en la relación madre-hijo y en Julián; de igual manera creo necesario enviar un mensaje al contexto escolar para incluirlo en este proceso interventivo.

Puedo identificar varios órdenes del cambio obtenido en todo el proceso. Primero observo el ajuste del sistema parental y la solución del impase que venía gestándose en virtud de sus desacuerdos internos como sistema. Segundo, ese cambio obtenido del ajuste parental, permitió liberar a Julián de la triangulación en el sistema parental y ver con esperanza la consolidación de un sistema protector para él. Tercero, veo en la postura de la madre una restitución de la historia de dolor y sufrimiento y cómo estos relatos dominantes fueron cambiados por relatos alternos de esperanza y mejoramiento. Cuarto, observo en Julián cambios en su self, tanto en su tono emocional como en su modo de asumir los desafíos que le corresponden en su proceso de individuación. En general puedo observar una familia mejor configurada en su organización funcional y en la reorganización de sus formas de vinculación, conectado ello a una historia de esperanza para enfrentar las vicisitudes como sistema familiar. En términos psicológicos se puede observar una mejor vinculación del self de cada uno consigo mismo y con el conjunto de las relaciones de todo el sistema familiar. Hay una mejoría emocional, ampliaron su experiencia vital y están tomando decisiones en sus relaciones.

En general, se activaron los mecanismos para que los consultantes gestionen mejor sus recursos y se integren mejor al sistema familiar, y a la familia en general la observamos con un provenir más promisorio para enfrentar los desafíos que le corresponden a su ciclo vital; al 
respecto, se observó en la familia un acercamiento afectivo, el fortalecimiento de los roles familiares, una mejor comunicación entre ellos y una vinculación más saludable.

Si bien es cierto tengo la sensación de haber suspendido el proceso antes de lo previsto por las circunstancias de contexto, experimento haber potenciado los cambios necesarios para generar una transformación del sistema consultante.

\section{Carta enviada al colegio}

Señores profesores

Institución

Cordial saludo.

Sabedores de las dificultades que ustedes han tenido en el manejo del comportamiento de Julián, deseamos en primer lugar felicitarlos por sus esfuerzos en la labor educativa respectiva.

Hemos estado estudiando con Julián y su familia esta misma preocupación que está expuesta como dificultades de Julián. Al respecto hemos comprendido que los comportamientos emocionales de Julián están relacionados una parte con su propia comprensión y la otra con los contextos interaccionales donde Julián comparte; hemos encontrado un niño inteligente y sensible que se altera y que en ocasiones no pone límite a su ira y al respecto hemos observado que si nos relacionamos con él sin descalificarlo, sin agredirlo y con un compromiso de escucharle en sus necesidades de reconocimiento y valoración personal, a la vez que colocarle límites claros a su conducta, él mejorará; ya hemos observado cambios en su familia. El reto entonces consiste en cómo moldear su fuerza, su temperamento y utilizar su nobleza e inteligencia para que comprenda las situaciones de su adaptación social y el efecto de su comportamiento positivo o negativo con el entorno.

Hemos entendido también que él, la familia y el colegio requieren aportar su granito de arena para que dialogando consolidemos 
un modelo de protección saludable para que Julián obtenga los resultados que debe tener en el momento actual; también hemos observado que entre más se le corrija y se le rotule como niño problema, él se deprime y se agita ante estas situaciones; en ocasiones entra en confusión y no sabe qué hacer. Al contrario, si lo escuchamos en sus necesidades y equilibramos nuestras emociones para tratarlo en los momentos difíciles, él logra un nivel de equilibrio y llega a utilizar su inteligencia emocional con mayor propiedad. La relación de la madre con él ha mejorado mucho y el aporte de su familia, incluido su padrastro ha sido muy beneficioso y hemos observado en este sentido que a mayor compromiso y madurez emocional con la que los adultos lo tratemos, la respuestas de Julián son cada vez más significativas de un logro de conciencia sobre sus interacciones sociales.

Por todo ello, un reconocimiento al colegio, a sus padres y al niño por querer mejorar la vida de él, de su familia y las relaciones en el colegio. Con su experiencia como institución podrían ayudar a Julián y su familia a orientar mejor a Julián y transformar el rótulo de niño medicado a un niño que aprende y se adapta a sus ritmos. Creemos que este proceso educativo y de aprendizaje es responsabilidad de todos, sobre todo entendiendo su labor como educadores.

Por último es necesario señalar que Julián ha tenido experiencias saludables con algunos profesores y no saludables con otros. Es importante crear para él modelos pedagógicos solidarios, pensar siempre en los modos como nos relacionamos con él.

Estaremos atentos en la medida de las posibilidades en compartir con ustedes esta experiencia. En todo caso, ustedes son unos testigos fundamentales y coautores importantes en la historia de Julián. Él, su familia y nosotros como equipo terapéutico valoraremos su participación en este proceso.

Atentamente, 


\section{Reporte de seguimiento al caso}

Realizo una llamada de seguimiento y hablo con la madre; al respecto ella reporta mantenimiento de los niveles de cambio obtenidos en las relaciones entre los miembros de la familia, cuenta breves recaídas, pero sobre todo sostiene la unión de todos respecto a mejorar sus formas de relacionarse, consolidando así la idea de avanzar en el viaje del barco, metáfora que le quedó sonando a ella y su familia.

De igual manera reporta que el niño acude frecuentemente a la idea de utilizar su inteligencia de la mejor manera. Se reporta también una mejor convivencia en el sistema de padres y una entrega de mayor tiempo a la convivencia por parte del padrastro. En este sentido han mantenido los acuerdos de la pareja en torno al manejo de las relaciones con sus familias de origen. Con respecto al colegio, la madre reporta que el informe gustó mucho a la coordinadora académica, a la psicóloga del colegio y a varios profesores y dice que manifestaron el interés para establecer contacto con el terapeuta encargado. Todo ello señala el efecto obtenido en el proceso establecido.

\section{Síntesis de la evolución de la subjetividad en el caso de Julián}

La historia del problema centrada en las dificultades del niño era coherente con el estancamiento en la historia familiar nuclear en tanto que sus acontecimientos generadores de dolor se hacían presentes en el significado del síntoma. Este se conectaba también a la segunda unión de la madre que requería decisiones de sentido para construir una nueva organización familiar. La lectura hecha por otras instancias tales como la medicalización y la manera de observar el comportamiento en el colegio, generaban aún más estancamiento en la evolución del sistema familiar y dejaban al niño aún más anclado en una condición de atrapamiento que impedía darle libertad a su self. Esto se hacía evidente en los relatos dominantes del self de la madre y del self del padrastro y era reafirmado por el self del niño, haciendo extensiva esta lectura al contexto escolar. Estos relatos dominantes, se relacionaban con la pauta interaccional de estos sistemas con el niño, de tal forma 
que anclaban el síntoma en un ecosistema plasmado de quejas, reiteraciones, control y estancamiento.

Los dispositivos del cambio se centraron en tres órdenes: 1) Viabilizar las posibilidades de organizar la nueva familia, para lo cual fue necesario desplegar las subjetividades de los miembros del sistema de padres y generar con ello una coordinación de sentido que les permitiera visualizarse en una nueva composición interaccional entre ellos como padres y el niño y los hijos como fundamento dinamizador de este sistema. 2) Movilizar las historias de la familia a partir de poner en marcha la subjetividad de cada uno de los participantes, especialmente la subjetividad de la madre y del niño en tanto que sus voces encarnaban la síntesis de la historia de pérdida de uno de sus hijos y reafirmaba la historia de descalificaciones de la madre por su familia de origen y del niño por los sistemas involucrados en su contexto ecológico en el cual se desempeña. El relato fue el dispositivo fundamental para poner en marcha las subjetividades en interacción y crear unos marcos de sentido compartido caracterizados por la reconciliación entre ellos y el espíritu del niño perdido, para viabilizar la capacidad de cada uno de los participantes para transformar su percepción personal e interaccional acerca de lo acontecido. 3) Ir expandiendo las posibilidades de intervención ecológica del caso, en tanto que se requería abordar la familia de origen del niño, la cual se había desintegrado y se hacía necesario recomponer el orden simbólico de la vinculación entre madre e hijos; de igual manera hacer extensiva la intervención al sistema escolar, toda vez que la definición del problema fundada en la medicalización y el control resonaba en la historia de control de la madre y del padrastro y se conectaba con el carácter de la relación de confusión identitaria entre el niño y el padre biológico.

El rol del terapeuta estuvo caracterizado por ser un viabilizador del proceso, animado siempre con la intención de proteger a todos los miembros del sistema, especialmente al niño, en virtud de la percepción que iba teniendo de las condiciones de vulnerabilidad en las que él se desenvolvía; de igual manera el reconocimiento de los recursos de todos los participantes para ser desafiados en las posibilidades de construir nuevas perspectivas de vida; en este sentido, simultáneamente 
en la medida que protegía los sistemas participantes, jugaba el papel de provocador del sistema para desafiar así los relatos dominantes que anclaban la estructura de vínculos inadecuados en la protección del niño, de la madre, de los hijos e inclusive del padrastro.

La hipótesis central que el terapeuta concibió fue la de establecer una relación entre los sistemas de significación presentes en la historia, especialmente referidos a dolor, sufrimiento, quejas, necesidad de control, sentimientos de descalificación e impotencia, con los modos de vinculación tales como confusión en los roles, paradojas en la posición de los participantes y dobles mensajes en el orden de la vinculación emocional presentes en los sistemas interactuantes. En este sentido la tarea central inicial era movilizar el cambio al poner en marcha las subjetividades de los actores en el marco de los subsistemas que trabajaba (parental, madre-hijo o madre-hijos), con miras a observar la evolución de todo el sistema familiar; en un segundo momento se hizo extensiva esta posibilidad a la institución educativa, al plantear una sugerencia de cambio en orden de las relaciones del niño con la institución.

La autorreferencia del terapeuta en consonancia con las posturas emocionales de los participantes en el proceso, fue muy importante en la medida en que resonaba para generar las alianzas y compromisos de cambio que eran necesarios para garantizar la confrontación de cada uno los participantes.

Los cambios obtenidos encuentran su sentido en el ajuste del sistema parental, en la reconstrucción de la historia vivida por la madre y sus hijos, en la emergencia de los recursos del niño al hacer expansivo su self en el proceso de subjetivación y en la resonancia de los sistemas amplios.

Un principio claro para evidenciar como terapeuta el cambio en un proceso terapéutico, es el de identificar en mi propia vivencia emocional el cómo sentí el proceso y el cambio. En este aspecto el sentimiento es el de haber experimentado un proceso potente para transformar el dolor y el sufrimiento humano en posibilidades de mejoramiento de la vida de los participantes; de haber logrado activar un sistema familiar estancado en un síntoma centrado en el niño; de igual manera, sentir 
a un niño liberarse como persona de los contextos de descalificación y predeterminación de un rótulo.

En síntesis puedo concluir que en la medida que se ponga en marcha la subjetividad de los participantes de un sistema conversacional e interactivo, las posibilidades de enriquecer la intersubjetividad son elocuentes; es decir, el acople emocional del sistema terapéutico está relacionado con poner en marcha los mecanismos de la intersubjetividad entre los participantes.

\section{Dinámica de la subjetividad de consultantes y terapeutas en los dos casos}

Conforme a los objetivos del estudio, en esta sección se presentan los elementos más destacados de la interacción entre las subjetividades de los participantes en los procesos terapéuticos analizados.

En primer lugar, se observa la función de la resonancia en el proceso de transformación de los participantes. Se diría que esa intersección amplificada de los ingredientes de los marcos de referencia y de las vivencias de consultantes y terapeutas, genera un clima emocional y una forma de vinculación en el contexto de la terapia, gracias a los cuales ambas partes tienen acceso a experiencias y recuerdos que están sumergidos en el mundo psíquico de los consultantes y relativamente desconectados de sus motivos de consulta, a pesar de su trascendencia en el surgimiento y mantenimiento de las situaciones perturbadoras y sintomáticas. Es decir, la sensibilidad del terapeuta para usar el impacto que desencadenan en su propia vivencia ciertos elementos de la presencia, la forma de interactuar y el relato de los consultantes, se convierte en una suerte de brújula para orientar el proceso.

Por lo tanto, ese interjuego de resonancias y disonancias orienta la conducción de la terapia de una manera tal, que las primeras facilitan la compenetración y el contacto humano necesario para que los consultantes tomen el riesgo de aproximarse a esas experiencias que se asocian con emociones desagradables que producen un efecto de malestar y de parálisis, sin cuyo procesamiento es imposible la resolución del motivo de consulta, pues ellas son el signo de alarma 
que alerta sobre la intensificación de esas emociones que son vividas por los consultantes como inmanejables y ambiguamente protectoras pero amenazantes. Esto significa que la sensibilidad y la capacidad de contención del terapeuta se ponen en juego para estimular ese acercamiento a lo temido, como ocurrió en el caso de la madre de Julián con respecto a la pérdida de su hijo y en el de Laura hacia la pérdida de su rumbo, de su madre y luego de su compañero.

En ese camino, las disonancias entre los marcos de referencia y las vivencias de consultantes y terapeutas señalan puntos críticos obstaculizadores del cambio, que indican la necesidad de hacer movimientos estratégicos y técnicos que amplíen el panorama y activen recursos de protección para destrabar la ruta hacia el cambio. Ejemplos de tales movimientos fueron la convocatoria del padre de Laura a la terapia y la relectura de su historia personal a través de fotos; en el caso de Julián, fue útil la confrontación serena pero incisiva del terapeuta sobre el compromiso de los padres para incluirse como sujetos activos del cambio y la participación alternada de los miembros de la pareja en las sesiones.

El efecto movilizador de esas estrategias tendría que ver con la creación de un microcontexto que hipotéticamente el terapeuta asume como propicio para acceder a los elementos en disonancia, considerados desde su punto de vista como cruciales para desencadenar el cambio. Solo cuando esas disonancias se convierten en resonancias en cuanto adquieren un sentido compartido por consultantes y terapeutas, se puede continuar avanzando en el proceso. Así, ocurrió cuando los padres de Julián se reconocieron como actores del cambio y cuando Laura fue reaccionando a cuestionamientos y confrontaciones sobre sus capacidades descalificadas y logró declarar sus necesidades y su postura en las relaciones con el padre y con el compañero.

Para proceder de la forma descrita, es indispensable que las historias relatadas, los comportamientos y las interacciones que aparecen en la terapia no sean tomados como datos para alimentar el marco de referencia del terapeuta y su construcción profesional o académica del caso, sino que, sin negar estas funciones de la información, lo involucren como participante en lo que técnicamente se llama el sistema 
terapéutico, pero que en la práctica representa que en verdad el terapeuta se use a sí mismo como persona, valga la redundancia, capaz de resonar desde todas las fibras, emocionales, valorativas, apreciativas, etc., al sufrimiento y a las búsquedas del otro, con quien en este contexto se relaciona como psicoterapeuta.

Aquí, la comprensión de ese involucramiento humano del terapeuta tiene por supuesto una interpretación muy distinta de la de otros enfoques psicológicos. Esa diferencia comienza desde la visión epistemológica que hace de consultantes y terapeutas dos sujetos en una interacción con roles bien definidos, a las que los ubican en la relación sujeto-terapeuta y objeto-paciente de intervención. Es comprensible que otros enfoques han pretendido preservar la asepsia de las relaciones para garantizar el carácter científico y profesional de la intervención, pero aquí, como lo han afirmado tantos terapeutas sistémicos, se acepta como una premisa sustancial, que el principal instrumento de trabajo del terapeuta no es otro que su propia subjetividad, dentro de la cual digiere a su manera las teorías y las técnicas de intervención y por supuesto las apreciaciones sobre los consultantes.

Naturalmente esto implica aceptar que el terapeuta no está exento de sesgos valorativos y de preferencias coherentes con su visión del mundo y por lo tanto el rigor de su trabajo no pretende ser evaluado con un quimérico rasero de objetividad, sino justamente con base en el efecto inmediato de sus acciones y de sus discursos en los consultantes, de modo que su competencia radica en afinar esa ya mencionada capacidad de resonancia para monitorear minuto a minuto la afinación del proceso terapéutico, en función de los objetivos y necesidades de los consultantes y de los acuerdos formulados como finalidades de la intervención.

Todo lo dicho es posible porque el contexto de la relación terapéutica se construye en un espacio y un tiempo real, donde paradójicamente las historias narradas con referentes cronológicos específicos se convierten en vivencias atemporales, cuya fuerza sigue tan vigente que continúa marcando el presente de los consultantes. En este orden de ideas, el papel de la memoria no es el del pasivo depósito de recuerdos, sino que es también un sistema vivo que se transforma con la 
vivencia reelaborada en la conversación terapéutica. Esta capacidad de la memoria sería la que ratifica la permanencia del cambio, pues si no hay una reorganización del depósito, por decirlo así, la repetición de los relatos de vida como datos cumplirá más bien la función de reforzar la misma historia de malestar. Es decir, el mantenimiento del cambio generado en la terapia requiere la transformación de la memoria. Por supuesto, no se trata de olvidar los hechos, sino de desconectarlos de un sentido y unos sentimientos insoportables para continuar el curso de la vida.

En esta misma línea, no sobra decir que tampoco se trata de la elaboración de los duelos por pérdidas como si en verdad hubiera un proceso estandarizado para lograrlo. Lo que se pretende es que las personas puedan reasumir los hechos de su vida dentro de un marco más amplio, para que aún situaciones tan dramáticas como la pérdida de un hijo, puedan ser integradas con un sentido favorable a la existencia. Estos planteamientos por supuesto implican unas creencias y unas posturas ante la vida, que transitan activamente en la terapia y deben por lo tanto ser monitoreadas por el terapeuta para que en verdad conduzcan a ampliar el horizonte de los consultantes y su margen de autonomía para asumir responsablemente su existencia. 


\section{Conclusiones}

Ta reflexión final gira alrededor del cumplimiento de los objetivos

¿de la investigación. Es decir, se refiere a la comprensión de la subjetividad como emergencia relacional en la psicoterapia sistémica, de la psicoterapia sistémica como dispositivo social de cambio de los procesos de subjetivación y de la forma cómo emergen y se transforman los procesos de vinculación, narración y memoria en cuanto dimensiones de la subjetividad. Por otra parte las reflexiones abordan la metodología de investigación -intervención propicia para aproximarse a los fenómenos investigados y a las consecuencias disciplinares, éticas y sociales de este tipo de investigación; así mismo el de ampliar las comprensiones de abordaje epistemológico de la objetividad- subjetividad en los procesos de acción social.

Es importante recordar que aquí se ha concebido la subjetividad como una noción para designar el espacio de expresión de un self que opera como observador de las experiencias conscientes del sujeto y que va de la mano de la reflexividad como capacidad de auto-observación de la propia experiencia individual y de construcción de sentido en la conversación consigo mismo y con otros, en este caso dentro del proceso terapéutico. Se asume que ese self contiene una identidad que se transforma constantemente en la interacción con referentes diversos 
y complejos que alimentan, lo que Leff (2010) llama procesos de desidentificación, reidentificación y redenominación del ser. Dichos procesos encuentran en la psicoterapia un lugar privilegiado para operar, en función de la transformación del sujeto y de su liberación a través del establecimiento de nuevas formas de conciencia de sí, que se manifiestan en los cambios de los discursos con los que se identifica el sujeto, así como en el cuerpo, los gestos, los sentimientos, los pensamientos y las prácticas relacionales.

Desde este punto de vista la identidad no equivale a "ser" sino a "saberse y sentirse" dentro de un mundo compartido con otros sujetos específicos en el tejido relacional que da lugar a los eventos, los significados y los recuerdos que se configuran mutuamente. Vista en este sentido, la psicoterapia es un espacio, una especie de macroscopio donde se amplifica el mundo psicológico para examinar con detenimiento cómo se han urdido el sufrimiento y el estancamiento de la vida y sobre todo cómo puede reavivarse el circuito del crecimiento en los consultantes.

Esta aproximación a la psicoterapia como dispositivo de cambio se distancia claramente, como ya se ha dicho, de las perspectivas que acuden a la noción de enfermedad para explicar el dolor emocional y existencial, porque se aferran a la epistemología lineal y reduccionista de lo humano a lo biológico como dimensión material. Los casos expuestos como ilustración de los procesos de cambio que pueden ocurrir en la psicoterapia son una ocasión para expresar cómo se concibe la evidencia desde esta perspectiva.

Para comenzar, es necesario tener en cuenta que la evaluación constructivista asevera que ninguna evaluación está libre de valores porque cada acto de evaluación es político, dados los valores del evaluador y la pluralidad de valores implicados en la interpretación de los hallazgos (Guba \& Lincoln, 1989). A esto añade Foucault (1980) que todas las aplicaciones del conocimiento llevan valores implícitos y así favorecen ciertas formas de vida en quienes los utilizan.

Como afirman Gergen, Josselson \& Freeman (2015) con el advenimiento "oficial" de la investigación cualitativa a la estructura de la APA, se le ha abierto un espacio significativo a un nuevo espíritu de 
pluralismo en la psicología como disciplina y con él florecen múltiples visiones y nuevas prácticas de investigación. No se trata de excluir las tradiciones anteriores, pues de hecho muchos investigadores cualitativos integran en su trabajo los tipos de medidas y estadísticas comunes en tales tradiciones. Lo interesante es que el movimiento cualitativo trae consigo concepciones alternativas del conocimiento con sus modos contrastantes de investigación, como la hermenéutica, el construccionismo y la evaluación de la praxis, cada uno de los cuales ofrece posibilidades distintas a las de acudir a las bases empíricas para proponer teorías generalizables. Estas opciones también esclarecen los valores asociados a la investigación al estimular su explicitación, contrario a la investigación tradicional que pretende formular conocimientos valorativamente neutrales.

Además, habría que agregar al esquema Habermasiano de acción social (Schuster, 2002), el tipo de acción social basado en el enfoque sistémico constructivista construccionista. En este enfoque la racionalidad se comprende en la intersubjetividad, el concepto del mundo se fundamenta en la hermenéutica experiencial sobre la cual opera la psicoterapia, sin pretensiones de validez científica y sí en la búsqueda de generación de la novedad. En esta forma de operar, la relación entre autores e interpretantes se reemplaza por la de personas en interacción y la actitud del científico deja de cimentarse en la objetividad-relatividad y pasa a establecerse en una postura de solidaridad en la construcción del nuevo conocimiento.

Hacer investigación que no solo reconoce sino que se basa en la explicitación de los valores de los investigadores trae un aire de libertad y de expansión a los profesionales y a la psicología, sin negar la importancia del rigor que los psicólogos en el siglo pasado quisieron darle a la disciplina para garantizar su estatuto de ciencia, siendo leales al positivismo que culturalmente así fue aceptado. Por lo tanto, sin negar la utilidad de la información que permite predecir el comportamiento de los fenómenos, desde la investigación cualitativa se considera que el conocimiento de la acción humana es incompleto sin la comprensión de la experiencia vivida como sujetos. La medida exacta del comportamiento de un individuo a través del tiempo y el espacio 
nunca permitiría comprender, por ejemplo, cómo la vida de una persona se organiza alrededor de una búsqueda espiritual. En efecto, la vida subjetiva es el fenómeno central de la condición humana y así lo entienden los eruditos en los campos fenomenológico, constructivista y de la narrativa, entre otros.

Esto ratificaría el aporte de este trabajo, tanto en cuanto a la validación de las teorías y referentes sistémicos a los que declararon haber acudido los terapeutas investigadores, como sobre todo en cuanto a mostrar las posibilidades de una comprensión longitudinal del cambio mediante el microanálisis de los textos de las sesiones, para intentar evidenciar los sutiles motores del cambio en los intersticios de las subjetividades y de las interacciones entre los participantes.

Así aparece otra de las diferencias con el planteamiento investigativo tradicional que presume la estabilidad del fenómeno de investigación, mientras aquí nos hemos ocupado justamente del cambio, basado en la maleabilidad de los sujetos y de su existencia, ayudándoles a ser fieles a sí mismos, lo cual encarna de hecho unos valores y creencias específicos acerca de la vida.

Podría decirse que la aplicación de los métodos fenomenológicos implementados mediante la distinción establecida entre las perspectivas de primera, segunda y tercera persona, ha facilitado articular la estructura de la experiencia subjetiva a través de la conversación terapéutica, para contribuir así a corroborar ciertas comprensiones sobre la gestación de las dificultades emocionales y su disolución, asociadas ineludiblemente a las movilizaciones en las interacciones y en la estructuración de los roles y la vinculación.

Por su parte, el ejercicio de la psicoterapia como una conversación narrativa muestra una vez más su valor como dispositivo que aprovecha los contenidos y los procesos de la memoria para rehacer la historia encarnada como condición para el cambio. No obstante, es importante destacar que si se mira con detenimiento cada uno de los casos, ninguno de los dos terapeutas podría ser ubicado específicamente en alguna de las escuelas de terapia sistémica. Si se asume que la postura estratégica es aquella donde cada caso y cada persona son acogidos como únicos e irrepetibles y por lo tanto requieren un abordaje 
también único y particular, es allí donde podrían ubicarse. Esto pudo apreciarse en que durante los procesos terapéuticos se incluyeron variadas técnicas y metáforas, así como formas de interacción, desde las llamadas preguntas lineales hasta confrontaciones a los marcos de referencia y a las formas de interacción de los consultantes.

Específicamente, puede afirmarse que los relatos que encarnaban los problemas, habían fijado rígidamente las identidades de los participantes, pero en la puesta en marcha de la dinámica de la subjetividad en la terapia, esos relatos y la correspondiente identidad fueron movilizados. Así, las personas que estaban deslegitimadas y presas en los relatos de los otros, se transformaron en personas capaces de participar en la construcción de su propia legitimidad. A su vez, esto implica que para cambiar las pautas de interacción en los sistemas participantes, se requiere que se modifiquen los relatos, para así transformar las identidades, resignificar las vivencias del self y posicionarse en el discurso en un lugar legitimador, como se evidencia por ejemplo, en el cambio de posición en la narración que logra cada participante alrededor de la situación "problema" a medida que emerge el nuevo relato.

Por otra parte, también aparece abiertamente la conexión entre historia y memoria en las posiciones de poder que representan las voces narrativas dominantes en el contexto de la intervención. Es decir, el relato dominante de los consultantes sobre el problema y sus causas excluye de la memoria una serie de acontecimientos claves para ampliar la perspectiva y como está generalmente atado a roles de poder dentro de los sistemas significativos, se impone esa versión dominante, bien sea por parte de la persona portadora del problema o de quienes solicitan la intervención. Por lo tanto, la nueva historia se va construyendo en ese interjuego donde las posturas, los roles, los recuerdos y los relatos son atravesados por las dinámicas de la subjetividad y la intersubjetividad. Es así como esta movilización se constituye en mecanismo indispensable para hacer de la memoria un proceso reconstructivo, al servicio de la adaptación humana en el curso del tiempo.

El rumbo que tome la intervención dependerá entonces de la generación de procesos reflexivos y conversacionales asentados en la experiencia subjetiva, capaces de engendrar transformaciones consensuadas 
y protectoras. Esto significa que la narración revisada y enriquecida en la interlocución terapéutica permite la reconstrucción de la experiencia confusa o crítica y se constituye en un mecanismo de configuración y reconfiguración de la mente y la inteligencia adaptativa de los sistemas gracias a su paso por la subjetividad. Para que la conversación "terapéutica/interventiva" facilite la co-construcción de otros significados propicios para la integración y la cooperación dentro del sistema familiar y la participación de los sistemas amplios, se requiere evocar y relatar los significados y los efectos de la experiencia vivida, más allá de una historia dominante, que recurre a la memoria particular empobrecida y anquilosada. Esto implica la articulación de elementos emocionales, valorativos y representacionales significativos en y entre los miembros de las familias y los terapeutas.

En relación a los modos de abordaje psicoterapéutico de los problemas humanos, cabe señalar que las teorías que explican tales problemas requieren ser reconstruidas y adecuadas en el proceso mismo de la psicoterapia, toda vez que ellas corresponden a un nivel de realidad diferente (tercera persona) al de la vivencia del sufrimiento de cada persona (primera persona), para lo cual se requiere crear un contexto convivencial (segunda persona) que permita recrear la experiencia humana. Este proceso exige activar los mecanismos de la subjetividad y la intersubjetividad, porque al fin y al cabo, un ejercicio clínico de esta naturaleza reconstruye la teoría previa. Parafraseando a Pakman (2014), la subjetivación es entonces el modo como el sujeto reaparece en la teoría, por una necesidad de recuperar la textura sensual de la vida, ya que al convertirlo en objeto de la teoría, el sujeto ha sido despojado de su experiencia vital irrepetible. 


\section{Referencias}

Anderson, H. (1999). Conversación, lenguaje y posibilidades. Buenos Aires: Amorrortu.

Bateson, G. (1976). Pasos hacia una ecología de la mente. Buenos Aires: Ediciones Carlos Lohlé.

Bateson, G. (1993). Una unidad sagrada. Barcelona: Gedisa.

Bateson, G. (1997). Espíritu y naturaleza. Buenos Aires: Amorrortu.

Bateson, M.C. (1994). Peripheral vision: learning along the way. New York: Harper Collins.

Braunstein, N. (2013). Clasificar en psiquiatría. México: Siglo XxI editores.

Brubaker, R. y Cooper, F. (2000). Beyond 'identity'... Theory and society, 29, 1-47.

Castell, R. (1981). La Gestion des risques. Paris: Minuit.

Castro, L. (2012). ¿Es posible una integración teórica de los tratamientos psicológicos? Ponencia presentada en la Cátedra Colombiana de Psicología Mercedes Rodrigo.

Comisión de Regulación en Salud (CRES). Acuerdo 029 de 2011 sobre Plan Obligatorio de Salud. Diario Oficial 48298 del 30 de diciembre de 2011. Recuperado de http://www.alcaldiabogota.gov.co/sisjur/normas/Norma1.jsp?i=45257

Congreso de la República. Ley 1616 de 2013 Salud mental. Recuperado de Cyrulnik, B., Elkaïm, M., \& Maestre, M. (2010). Entre résilience et résonance. À l'écoute des émotions. París: Ed. Fabert. 
Dennett, D. (1991). Consciousness explained. Nueva York: Little Brown.

Díaz, J.L. (2008). La conciencia viviente. México: Fondo de Cultura Económica.

Díaz, J.L. (2014). Conocimiento médico y epistemología clínica. Conferencia presentada en la Universidad Externado de Colombia, en mayo 14 de 2014. Artículo en proceso de publicación.

Dubet, F. (1989). De la sociología de la identidad a la sociología del sujeto. Estudios sociológicos, 7(21), 519-545.

Dugas, L. (1917). La mémoire et l'oubli. París: Éditions Ernest Flammarion.

Dugas, L. (Juillet-Decembre, 1894). La mémoire brute et la mémoire organisée. Revue philosophique de la France et de L'Etranger, 38, 449-464.

Elkaïm, M. (1989). Si me amas, no me ames. Psicoterapia con enfoque sistémico. Buenos Aires: Gedisa.

Elkaïm, M. (2004). L'expérience personnelle du psychothérapeute: approche systémique et résonance. Psychothérapies, 24(3), 145-150.

Erickson, M. \& Rossi, E.L. (2001). El hombre de febrero. Apertura hacia la conciencia de si y la identidad en hipnoterapia. Buenos Aires: Amorrortu.

Foucault, M. (1966). El nacimiento de la clínica. México. Siglo xxi editores. Foucault, M. (1969). La arqueología del saber. (Versión en español, 1988, $13^{\mathrm{a}}$ edición). México: Siglo xxi editores.

Foucault, M. (1974). Historia de la medicalización, Segunda conferencia dictada en el curso de medicina social. Instituto de medicina social, Centro biomédico de la Universidad Estatal de Río de Janeiro. Educación médica y salud, 11(1), 3-25. Recuperado de http://www.terceridad.net/ Sistemasdesalud/Foucault, \%20M.\%20Historia \%20de\%201a\%20medicalizaci\%F3n.pdf.

Foucault, M. (1980). Power/Knowledge: selected interviews and other writings, 1972-1977. New York, NY: Pantheon.

Foucault, M. (1990). Tecnologías del Yo. Barcelona: Paidós Ibérica, S.A.

Foucault, M. (1996). La vida de los hombres infames. Buenos Aires: Editorial Acmé s.A.C.I.

Foucault, M. (2007). El nacimiento de la biopolítica. Buenos Aires, Argentina: Fondo de Cultura Económica.

Gadamer, H-G. (2001). El inicio de la sabiduría. Barcelona: Paidós.

Gergen, K.J. (1994). Realities and relationships: soundings in social construction. Cambridge, Ma.: Harvard University Press.

Gergen, K.J. (1996). Realidades y relaciones. Buenos Aires: Paidós.

Gergen, K.J. Josselson, R. \& Freeman, M. (January, 2015). The promises of qualitative inquiry. American psychologist, 70(1), 1-9. Recuperado de http://www.ncbi.nlm.nih.gov/pubmed/25581004 
Gilgun, J.F. (2011). Theory and case study research. Recuperado de http://www. smashwords.com/extreader/read/41031/1/theory-and-case-study-research

Gómez, J. (2006). De cómo abordar la subjetividad. En Desafíos en estudios sociales e interdisciplinariedad. Bogotá: Universidad Distrital Francisco José de Caldas.

González, F. (2012). La subjetividad y su significación para el estudio de los procesos políticos: sujeto, sociedad y política. En C. Piedrahita, Subjetividades politicas: desafíos y debates latinoamericanos. Bogotá: Universidad Distrital Francisco José de Caldas y CLAcso.

Gordon, D. \& Meyers-Anderson, M. (1981). Phoenix. Therapeutic patterns of Milton Erickson. Cupertino, Ca.: Meta Publications.

Havens, R.A. (Ed.) (1984). The wisdom of Milton H. Erickson. Human Behavior \& Psychotherapy. New York. Irvington Publishers Inc.

Hernández, A. (2010). Vinculos, individuación y ecología humana. Hacia una psicología clínica compleja. Bogotá: UsTA.

Hernández, A. (2013). Envejecimiento y longevidad: destino y devenir. Teoría, datos y vivencias. En proceso de publicación por la Universidad Externado de Colombia.

Hernández, A. (2014). ¿Para qué integrar las psicoterapias? Capítulo de obra colectiva en proceso de publicación, producto de la Cátedra Colombiana de Psicología Mercedes Rodrigo (2012) en sesión titulada ¿Es posible una integración teórica en psicoterapia?

Hernández, A. (2014). De las neurociencias a la inclusión del sujeto y la expansión de la conciencia: Investigación, Intervención y Desarrollo Humano. Conferencia dictada en la Cátedra Abierta del Área de Salud, Conocimiento Médico y Sociedad en la Universidad Externado de Colombia.

Houseman, M. (2003). Vers un modèle anthropologique de la pratique psychothérapeutique. Thérapie Familiale, 24, 309-332.

Jacques, J-M. \& Laurent, N. (2006). Expérience subjective et Neurosciences, le paradoxe du «moi». En Regards croisés sur le moi: Traditions orientales, traditions occidentales, Jean-Marie Jacques et Frans Goetghebeur (Eds.), Kunchab Editions. Recuperado de https://www.academia.edu/10385183/ Exp\%C3\%A9rience_subjective_et_Neurosciences_le_paradoxe_du_moi_

Le Moigne, J-L. (1995). Les épistémologies constructivistes. París: PUF, Que sais-je?

Le Moigne, J-L. (2007). Intelligence de la complexite: Les enjeux éthiques de la recherche et de l'intervention en éducation et formation n'appellent-ils pas un 'Nouveau discours de la méthode des études de notre temps'? Conférence au XV colloque de l'ARFISE, Portugal, février 2007. Recuperado de http://archive.mcxapc.org/docs/conseilscient/0802afirse.pdf 
Leff, E. (2010). El desvanecimiento del sujeto y la reinvención de las identidades colectivas en la era de la complejidad ambiental, Polis [En línea], 27. Recuperado de http://polis.revues.org/862

Luhmann, N. (1997). La clausura operacional de los sistemas psíquicos y sociales. En Fischer, H.R. y cols. (Comp.) El final de los grandes proyectos. Barcelona: Gedisa.

Maestría en Psicología Clínica y de Familia, Universidad Santo Tomás. (2014). Boletín informativo. Bogotá.

Miller, J.A. (1955). The magical number seven, plus or minus two some limits on our capacity for processing information. Psychological Review, 101(2), 343-352. Recuperado de http://spider.apa.org/ftdocs/rev/1994/ april/rev1012343.html

Ministerio de Salud y Protección Social - Colciencias. (2013). Detección temprana y diagnóstico del episodio depresivo y trastorno depresivo recurrente en adultos. Atención integral de los adultos con diagnóstico de episodio depresivo o trastorno depresivo recurrente - 2013 Guía No. 22. Bogotá. Recuperado de: https://www.minsalud.gov.co/sites/rid/Lists/BibliotecaDigital/RIDE/INEC/IETS/GPC_Comple_Depre\%20(1).pdf Recuperado de:

Minuchin, S. \& Fishman, H.C. (1981). Family therapy techniques. Cambridge: Massachusetts. Harvard University Press.

Minuchin, S. \& Fishman, S. (1977). Familias y terapia familiar. Barcelona. Gedisa. (La obra consultada es la $3^{\text {a }}$ edición, 1982).

Minuchin, S., Reiter, M.D. \& Borda, C. (2014). The craft of family therapy. New York: Routledge.

Morin, E. (1994). La complexité humaine. Paris: Flammarion.

Morin, E. (2001). La méthode. 5. L'humanité de l'humanité. L'identité bumaine. Paris: Ed. du Seuil.

Pakman, M. (2014). Texturas de la imaginación. Más allá de la ciencia empírica y del giro lingüístico. Barcelona: Gedisa

Passerini, L. (2006). Convertirse en sujeto en la época de la muerte del sujeto. En Memoria y utopía. La primacía de la intersubjetividad. Valencia: Universitat de Valencia.

Piedrahita, C. (2006). Subjetivación y subjetividades maquínicas. En Desafíos en estudios sociales e interdisciplinariedad. Bogotá: Universidad Distrital Francisco José de Caldas.

Ricoeur, P. (1996). Tiempo y narración. El tiempo narrado. México: Siglo XXI editores.

Roudinesco, E. (2005). El paciente, el terapeuta y el Estado. Buenos Aires: Siglo XXI editores Argentina. 
Schuster, F. (Compilador) (2002). Objetividad sin neutralidad valorativa según Jurgen Habermas. En Filosofía y métodos de las ciencias sociales. Buenos Aires: Manantial.

Sebeok, T.A. y Umiker-Sebok, J. (1987). Sherlok Holmes y Charles S. Pearce. El método de la investigación. Barcelona: Paidós.

Serna, A. (2012). Memoria y creencia: una mirada políticamente incorrecta a ciertas vindicaciones de la memoria. En García, Jiménez et al. (ed.), Las víctimas, entre la memoria y el olvido. Bogotá: Universidad Distrital Francisco José de Caldas y Centro de Memoria, Paz y Reconciliación del Distrito.

Serna, A. (2016). Subjetividad, memoria y creencia. Algunos elementos para una memoria de la memoria. En F. Guerrero (ed.), Convivencia y reconciliación. Construcción de nuevos vínculos sociales para una Colombia diferente. Cali: Pontificia Universidad Javeriana.

Simon, R. (1996/7). Es mucho más complicado. Entrevista a Salvador Minuchin. Perspectivas Sistémicas. [Artículos on line], 9(46). Recuperado de http://webcache.googleusercontent.com/search?q=cache:http://www. redsistemica.com.ar/sumarios 9. htm

Trappeniers, E. \& Boyer, A. (2004). Thérapie systémique: individus en interaction ou sujets en relation? Cahiers critiques de thérapie familiale et de pratiques de réseaux, 2(33), 161-178. Recuperado de www.cairn. info/revue-cahiers-critiques-de-therapie-familiale-2004-2-page-161.htm

Varela, F. (2000). El fenómeno de la vida. Santiago de Chile: Dolmen.

Varela, F. y Shear, J. (2005). Metodologías en primera persona: qué, por qué, cómo. Revista Gaceta Universitaria, 1(2), 148-160. Publicado originalmente en el Journal of Consciousness Studies, 1999, 6(2-3), 1-14. Recuperado de http://es.scribd.com/doc/62800665/Francisco-Varela-J-Shear-Metodologias-en-primera-persona-Que-Porque-Como

Wacquant, L. (2010). Socialiser, medicaliser ou penaliser: un choix politique. Entretien avec LoïcWacquant. Recuperado de http://1libertaire.free.fr/ Securitaire09.html.

Watzlawick, P. (1980). El lenguaje del cambio. Nueva técnica de la comunicación terapéutica. Barcelona: Herder.

Watzlawick, P., Beavin, H. \& Jackson, D. (1967 original en inglés, 1981). Teoría de la comunicación humana. Barcelona: Herder. 


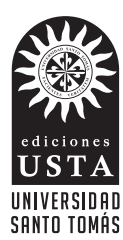

Esta obra se editó en Ediciones USTA,

Departamento Editorial de la Universidad Santo Tomás.

Se usó papel propalcote de 300 gramos para la carátula y papel bond beige de 75 gramos para páginas internas.

Tipografía de la familia Sabón. Impreso por Digiprint. 
Este texto presenta los hallazgos del proyecto institucional de investigación "La transformación de la subjetividad en la psicoterapia sistémica como dispositivo social de cambio ecológico" realizado desde la Maestría en Psicología Clínica y de Familia de la Universidad Santo Tomás. El texto expone los cimientos conceptuales, paradigmáticos y epistemológicos de la investigación; la metodología diseñada para comprender los cambios de las subjetividades en el sistema terapéutico; los procesos de transformación en dos casos analizados en profundidad; y las implicaciones disciplinares, éticas y formativas en el campo de la psicología clínica y la psicoterapia.

La subjetividad se entiende en este trabajo como una condición inherente a la formación del sujeto y un espacio de expresión del self-en-contexto, que opera como observador de las propias experiencias conscientes. La subjetividad va de la mano de la reflexividad como capacidad de auto-observación y de construcción de sentido en la conversación consigo mismo y con otros, en este caso, dentro de la psicoterapia.

Se espera que este texto responda algunos interrogantes sobre las conexiones entre el mundo psicológico individual y el mundo interaccional en el ejercicio de la psicoterapia sistémica. Se dirige por lo tanto a psicoterapeutas, psicólogos y profesionales del campo del bienestar humano y la salud mental, interesados en comprender los procesos de cambio que se activan en los dispositivos sociales de transformación.

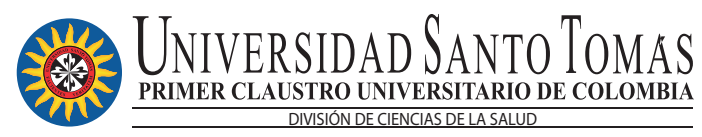

